System-Wide Water Resources Program

\title{
Structural Methods to Reduce Navigation Channel Shoaling
}

Trimbak M. Parchure

September 2005

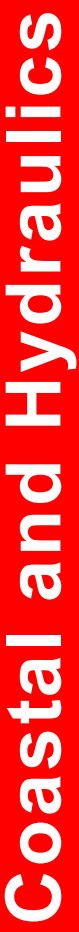




\section{Structural Methods to Reduce Navigation Channel Shoaling}

Trimbak M. Parchure

Coastal and Hydraulics Laboratory

U.S. Army Engineer Research and Development Center

3909 Halls Ferry Road

Vicksburg, MS 39180-6199

Final report

Approved for public release; distribution is unlimited 
ABSTRACT: Shoaling of harbors and navigation channels is a global problem. Expensive dredging operation must be undertaken to remove accumulated sediment and maintain navigable depths to continue uninterrupted navigation. Since the draft of commercial vessels and oil tankers is continually increasing, the navigation channels are getting wider, deeper and longer, thus requiring greater maintenance dredging. The length of a navigation channel depends upon the local geographical configuration and it may vary from less than a mile to 50 miles or more.

It is absolutely essential to determine the important factors at play before considering an appropriate method for reducing siltation in navigation channels. These factors include: type of sediment, identification of sediment source, critical natural parameters involved, time scale of shoaling occurrence, and total volume of sediment. The types of available measures include reduce/prevent/catch/divert sediment inflow from the source, and prevent sediment recirculation/deposition. These methods may also be classified alternatively as structural methods, nonstructural methods, and management/other methods. The best-suited option for a given project must be well studied in advance to ensure its efficient functioning for the intended purpose. Sometimes, a combination of various methods may have to be used.

Incorporating structural modifications at project sites is often a viable and economical option for reducing shoaling in harbors and navigation channels. This option includes construction of massive and expensive structures such as dikes of various types, bendway weirs, breakwaters, jetties, weir jetties, sediment barriers, sediment traps, channel closing structure, flow diversion structures such as dams and canals, and current deflector walls. Structural methods are the most prevailing options selected for many projects and they are found to be effective in reducing channel shoaling. Use of such structures is described in this report along with description of numerous studies and examples of sites where they have been used. This report describes various options available for the designers and field engineers. Projects where such methods have been successfully implemented have been cited. Simulations made with the help of a schematic numerical model are given. Although structural remedies are often effective, they are mostly site-specific and should not be adopted without examining their applicability at a site under consideration. Detailed studies in the form of physical modeling, numerical modeling, field data collection and analysis and examination of successful measures adopted at other sites should be undertaken to select the best possible option for a given site under consideration. Several parameters, including environmental impact, must be taken into account while selecting a set of technically feasible and economically viable options.

DISCLAIMER: The contents of this report are not to be used for advertising, publication, or promotional purposes. Citation of trade names does not constitute an official endorsement or approval of the use of such commercial products. All product names and trademarks cited are the property of their respective owners. The findings of this report are not to be construed as an official Department of the Army position unless so designated by other authorized documents. 


\section{Contents}

Conversion Factors, Non-SI to SI Units of Measurement................................ vii

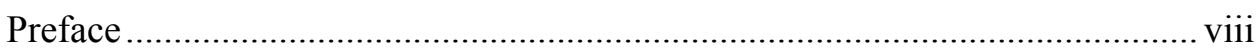

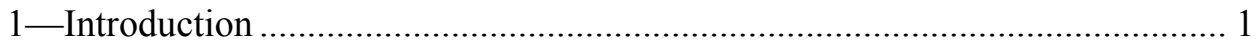

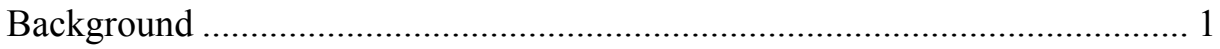

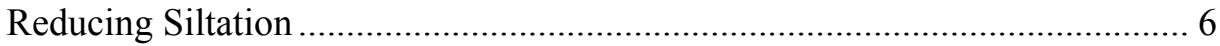

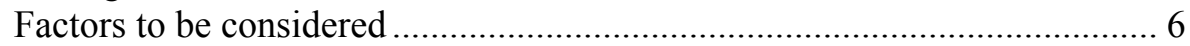

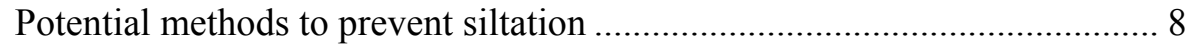

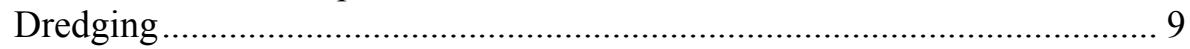

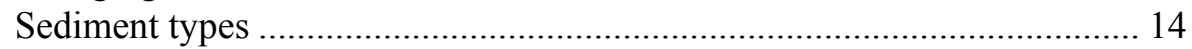

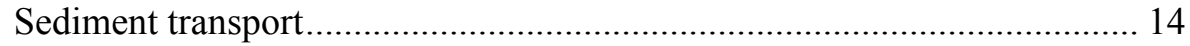

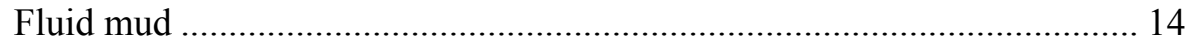

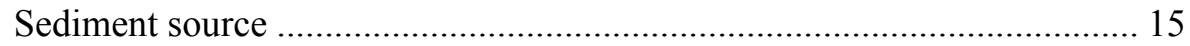

Sedimentary processes and human interference ...................................... 15

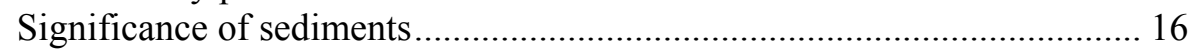

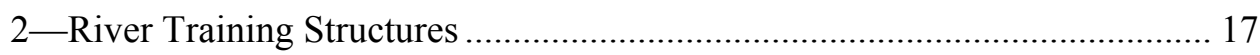

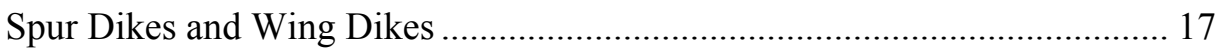

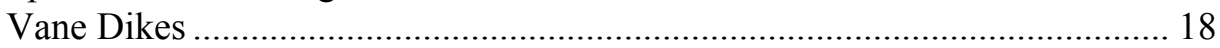

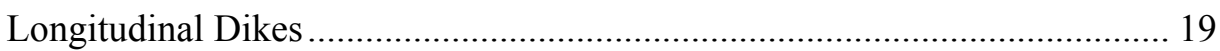

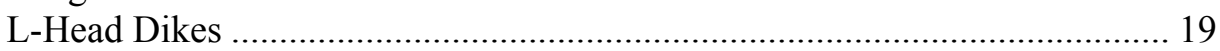

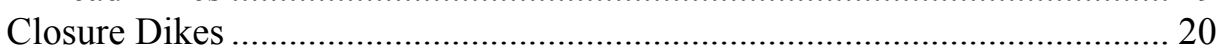

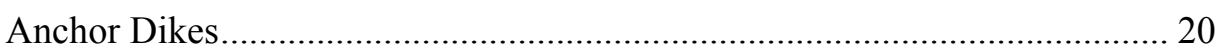

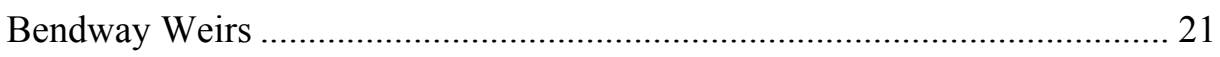

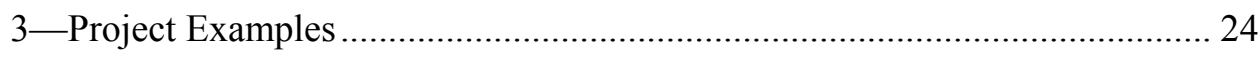

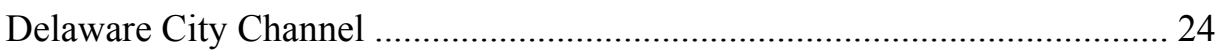

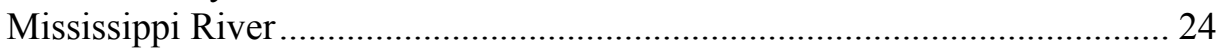

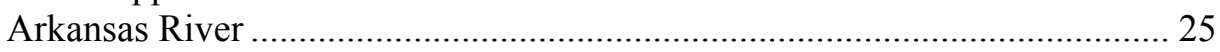

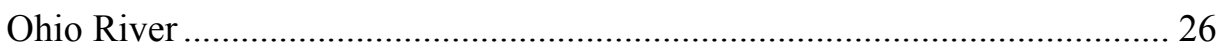

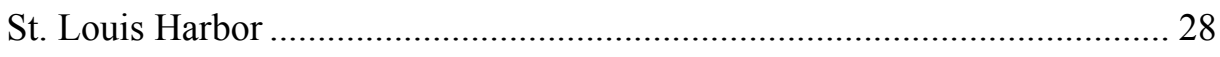

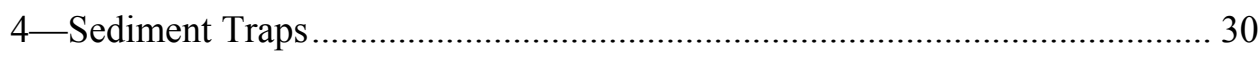

Sediment Trap Analysis ......................................................................... 30

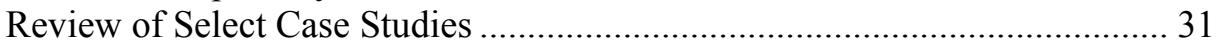

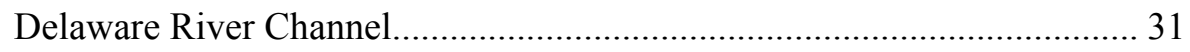

Channel Islands Harbor, CA................................................................... 31

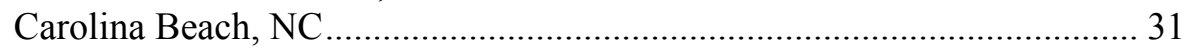

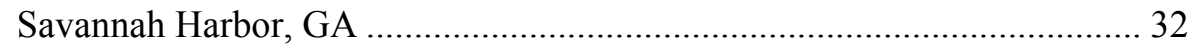




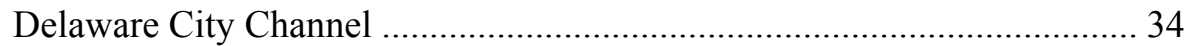

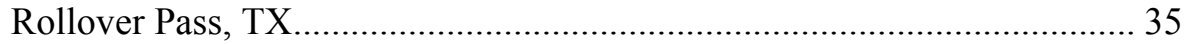

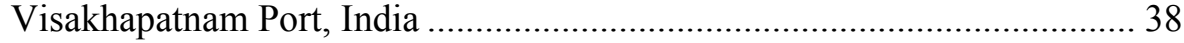

Colorado River, TX

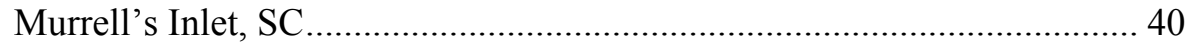

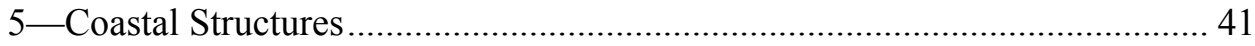

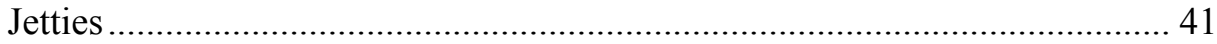

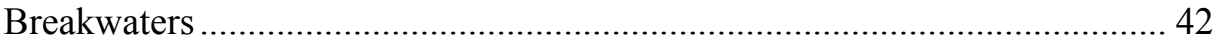

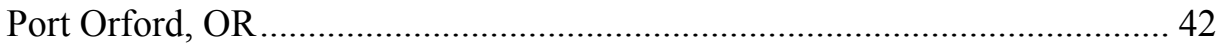

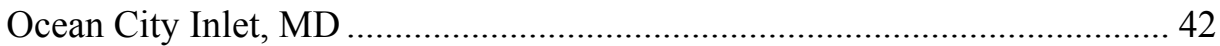

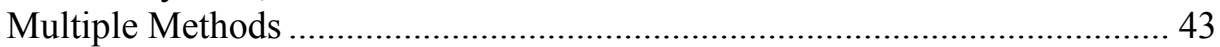

6-Other Structures and Multiple Structures ..................................................... 44

Current Deflector Wall at Hamburg, Germany ............................................... 44

Current Deflector Wall at Antwerp ............................................................ 45

Multiple Structures at Mare Island Naval Shipyard ...................................... 45

Sediment Barrier at La Quinta, TX ............................................................... 46

Flow Diversion at Charleston Harbor, SC ...................................................... 49

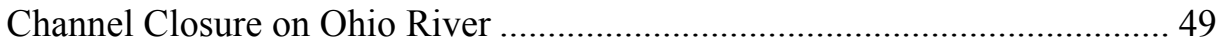

Channel Closure at Delaware River Channel ............................................... 50

Channel Closure at San Diego River........................................................... 50

Barrier at Dillingham Harbor, AK.............................................................. 50

Multiple Structures at Ninilchik Harbor, AK ……..................................... 52

Hudson River Channel ............................................................................... 53

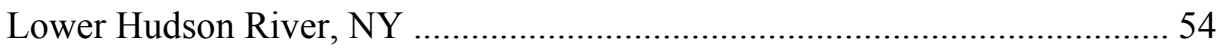

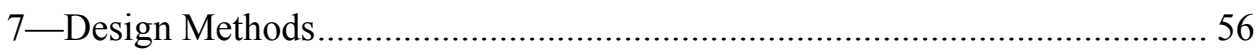

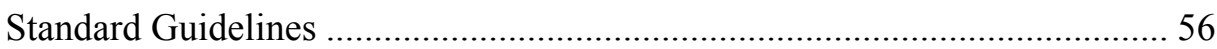

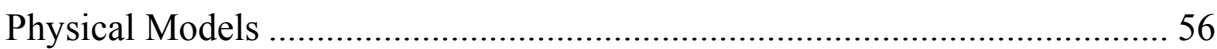

Numerical Models ....................................................................................... 57

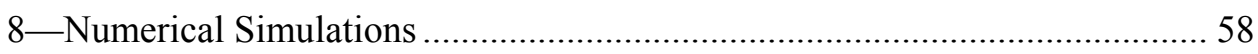

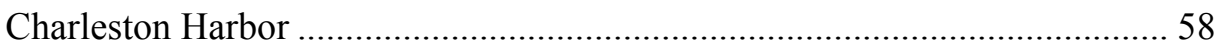

Ashley River, Charleston, SC ............................................................... 58

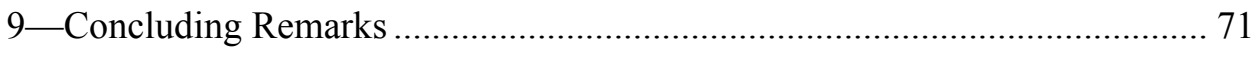

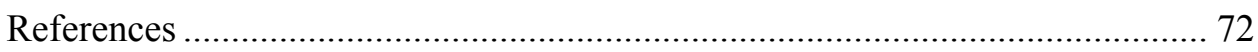

SF 298

\section{List of Figures}

Figure 1. Connecting channel at Rollover Pass, TX .................................2

Figure 2. Corpus Christi, TX, navigation channel .....................................

Figure 3. Sabine Neches, TX, inner navigation channel ...........................4 
Figure 4. Sabine Neches, TX, outer navigation channel ..........................5

Figure 5. Typical cross section of navigation channel...............................6

Figure 6. Zones of major siltation in Georgetown Harbor navigation

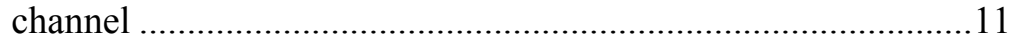

Figure 7. Georgetown Harbor navigation channel..................................12

Figure 8. Schematic layout of spur dikes.............................................18

Figure 9. Schematic layout of vane dikes .............................................. 18

Figure 10. Schematic layout of a longitudinal dike ..................................19

Figure 11. Schematic layout of L-head dikes ...........................................20

Figure 12. Schematic layout of closure dikes ........................................21

Figure 13. Schematic layout of anchor dikes...........................................21

Figure 14. Schematic layout of submerged bendway weirs .......................22

Figure 15. Dogtooth Bend reach of Mississippi River .............................23

Figure 16. Two wing dikes suggested for reducing shoaling at Smithland Locks and Dam ..................................................27

Figure 17. Dikes recommended at St. Louis Harbor, Mississippi River .....29

Figure 18. Sediment trap at Savannah Harbor ...........................................33

Figure 19. Median diameter (in microns) of bed sediment along GIWW at Rollover Pass ...........................................................36

Figure 20. Computed volumes of sediment accumulation in GIWW at

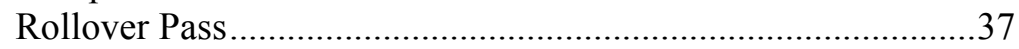

Figure 21. Recommended sediment trap layout at Rollover Pass.................38

Figure 22. Sediment trap at Visakhapatnam Harbor, India .........................39

Figure 23. Sediment basin at Colorado River mouth, TX ..........................40

Figure 24. CDW at Hamburg Harbor, Germany.........................................45

Figure 25. Layout of existing and extended La Quinta Navigation

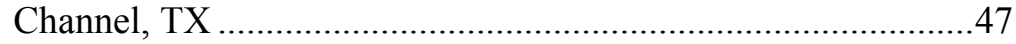

Figure 26. Layout of sediment barrier (armored levee) proposal at La

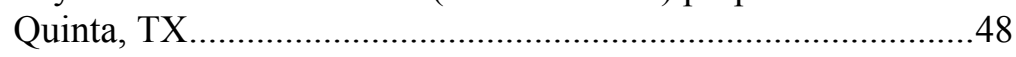

Figure 27. River flow diversion at San Diego River, CA...........................51

Figure 28. Flow pattern with a six-dike field..........................................59

Figure 29. Sediment accumulation due to a nine-dike field .......................60 
Figure 30. Bathymetry of Ashley River reach and two-dike field selected for study.

Figure 31. Boundary condition tidal curves used for numerical simulation .62

Figure 32. Tidal stages selected for obtaining flow vectors ......................63

Figure 33. Ebb flow pattern with two dikes at $26.5 \mathrm{hr}$..............................64

Figure 34. Ebb flow pattern with two dikes at $27 \mathrm{hr}$................................65

Figure 35. Ebb flow pattern without the two dikes at $27 \mathrm{hr}$.....................66

Figure 36. Ebb flow pattern with two dikes at $27.5 \mathrm{hr}$.............................67

Figure 37. Ebb flow pattern with two dikes at $33 \mathrm{hr}$................................68

Figure 38. Ebb flow pattern without the two dikes at $33 \mathrm{hr}$.....................69

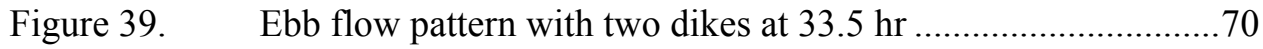




\section{Conversion Factors, Non-SI to SI Units of Measurement}

Non-SI units of measurement used in this report can be converted to SI units as follows:

\begin{tabular}{||l|l|l||}
\hline \hline Multiply & By & To Obtain \\
\hline \hline acres & $4,046.873$ & square meters \\
\hline cubic yards & 0.7645549 & cubic meters \\
\hline feet & 0.3048 & meters \\
\hline miles (U.S. statute) & 1.609347 & kilometers \\
\hline
\end{tabular}




\section{Preface}

Incorporating structural modifications at project sites is often a viable and economical option for reducing shoaling in harbors and navigation channels. This report describes various options available for the designers and field engineers. Projects where such methods have been successfully implemented have been cited. Simulations made with the help of a schematic numerical model are given. Funding for this study was provided under the regional sediment management research of the System-Wide Water Resources Program (SWWRP). Dr. Trimbak M. Parchure, Coastal and Hydraulics Laboratory (CHL), U.S. Army Engineer Research and Development Center (ERDC), Vicksburg, MS, was the principal investigator for the project and prepared this report. Ms. Soraya Sarruff, CHL, did the computer simulations and obtained flow patterns for the Ashley River project. Mr. Corey Foster, CHL, helped in collecting literature references and in compiling the report.

The work was conducted under general supervision of Dr. Robert T. McAdory, Chief, Estuarine Engineering Branch, CHL, Dr. Sandra Knight, Technical Director, CHL, and Mr. Thomas W. Richardson, Director, CHL.

COL James R. Rowan, EN, was Commander and Executive Director of ERDC. Dr. James R. Houston was Director. 


\section{Introduction}

\section{Background}

Most of the world's major estuarine, coastal, and inland harbors are connected to the sea. Ships access the berthing areas of these harbors through navigation channels. For the prevailing drafts of commercial vessels the required depth of navigation channel varies from about 10 to $15 \mathrm{~m}$. Large oil tankers require greater depths of up to $20 \mathrm{~m}$. Dredging is required to provide and maintain these depths. After initial navigation channel dredging, most projects require expensive, periodic maintenance dredging; port operating agencies have continually tried various methods to reduce the amount, frequency, and cost of dredging.

Location and length of a navigation channel depend on the local geographical configuration. Four examples are given below:

- A short channel, 0.25 mile long, cut through an outer coastal bar to connect a deepwater basin at Rollover Pass, TX, to the ocean (Figure 1). ${ }^{1}$

- A 50-mile-long protected channel at Corpus Christi, TX (Figure 2).

- A 35-mile-long protected channel at Sabine Neches, TX (Figure 3).

- A 20-mile-long outer channel in ocean exposed to waves at Sabine Neches (Figure 4).

In addition to navigation channels, ports also require areas such as turning basins, alongside berths, open jetties for berthing ships, and oil terminals. These areas often pose a challenge to dredging operations due to restricted space, occupancy by vessels, shallow foundations, and proximity of structures and land. Special dredging equipment is often necessary in these areas.

Shoaling of harbors and navigation channels is a global problem. Dredging must be undertaken to remove accumulated sediment and maintain navigable depths in order to continue uninterrupted navigation into and out of ports. Attempts have been made on several projects to reduce shoaling in order to reduce the recurring cost of dredging. An extensive literature review indicated several methods that have been successfully employed by projects. All of these are site-specific, and universally applicable methods do not exist.

1 A table of factors for converting non-SI units of measurement to SI units is presented on page vii. 


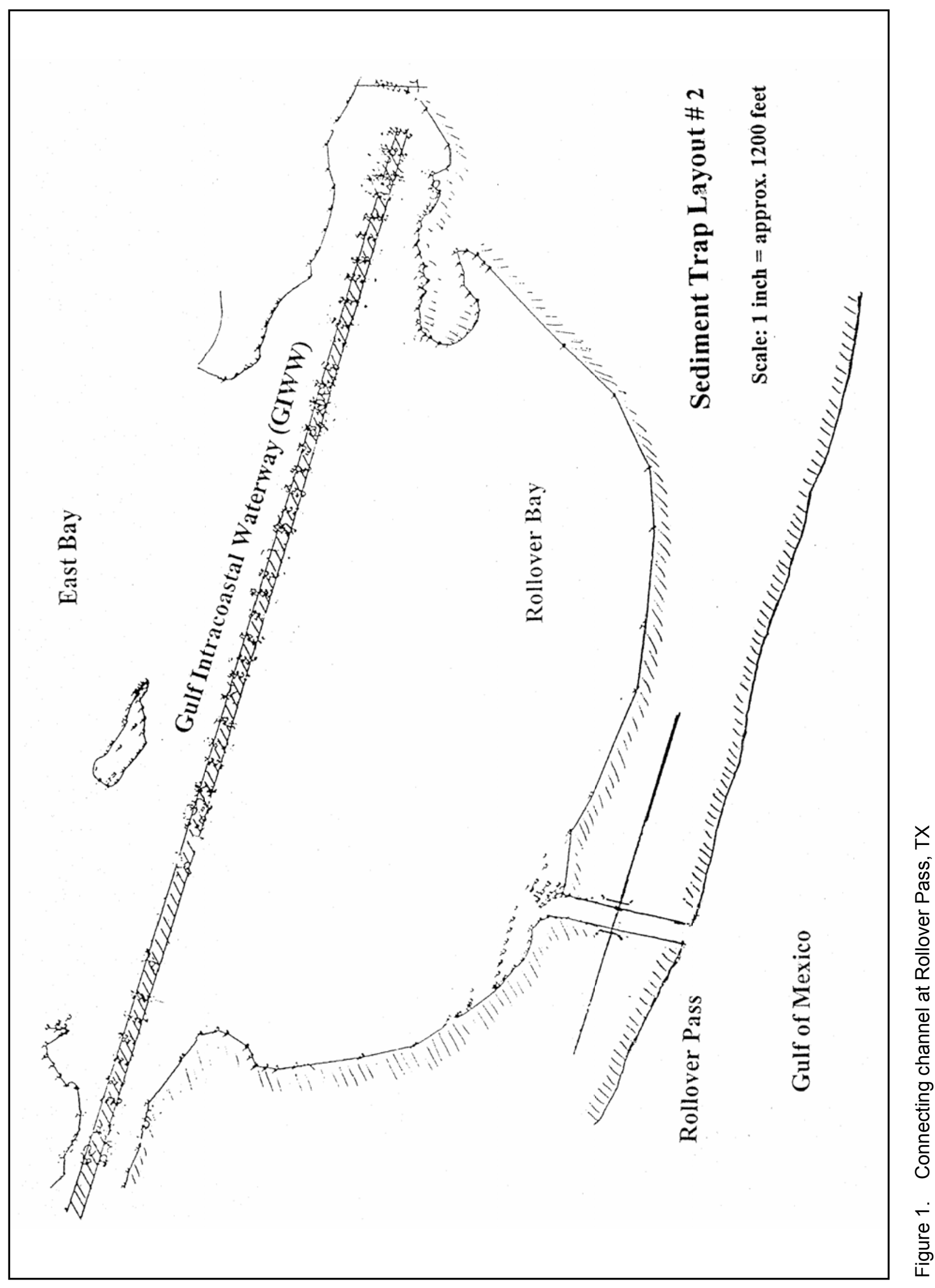




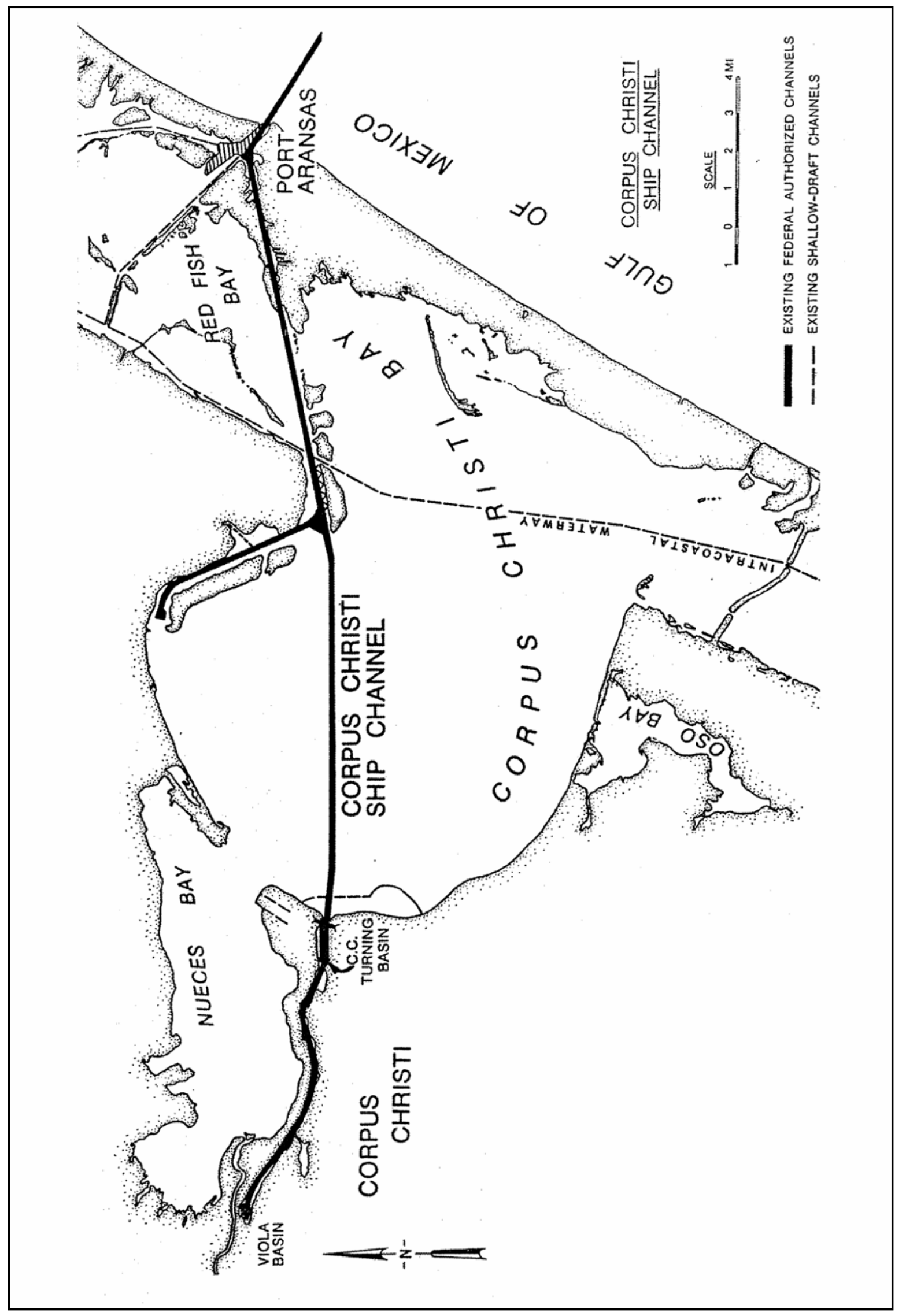

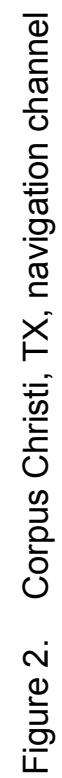




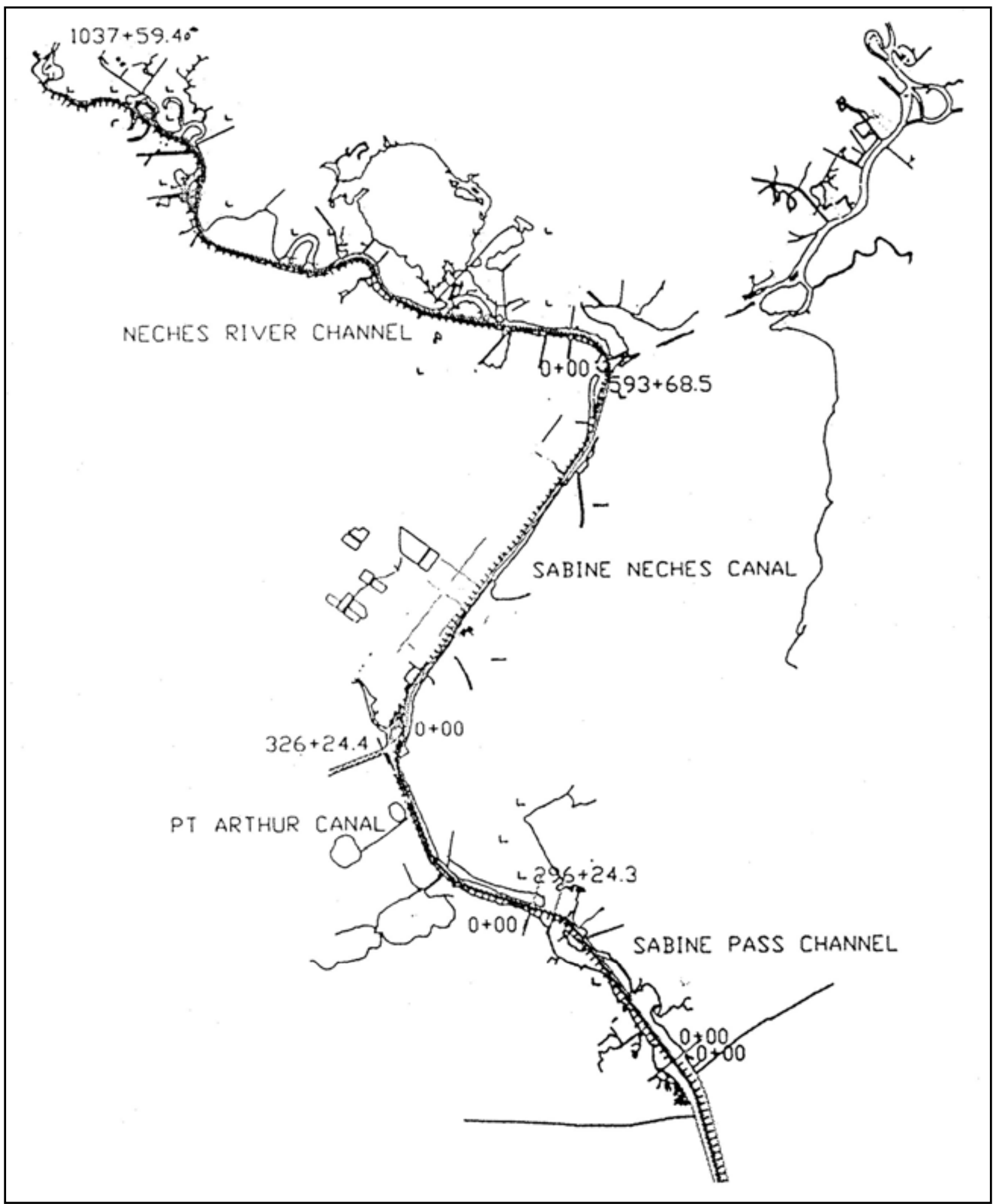

Figure 3. Sabine Neches, TX, inner navigation channel 


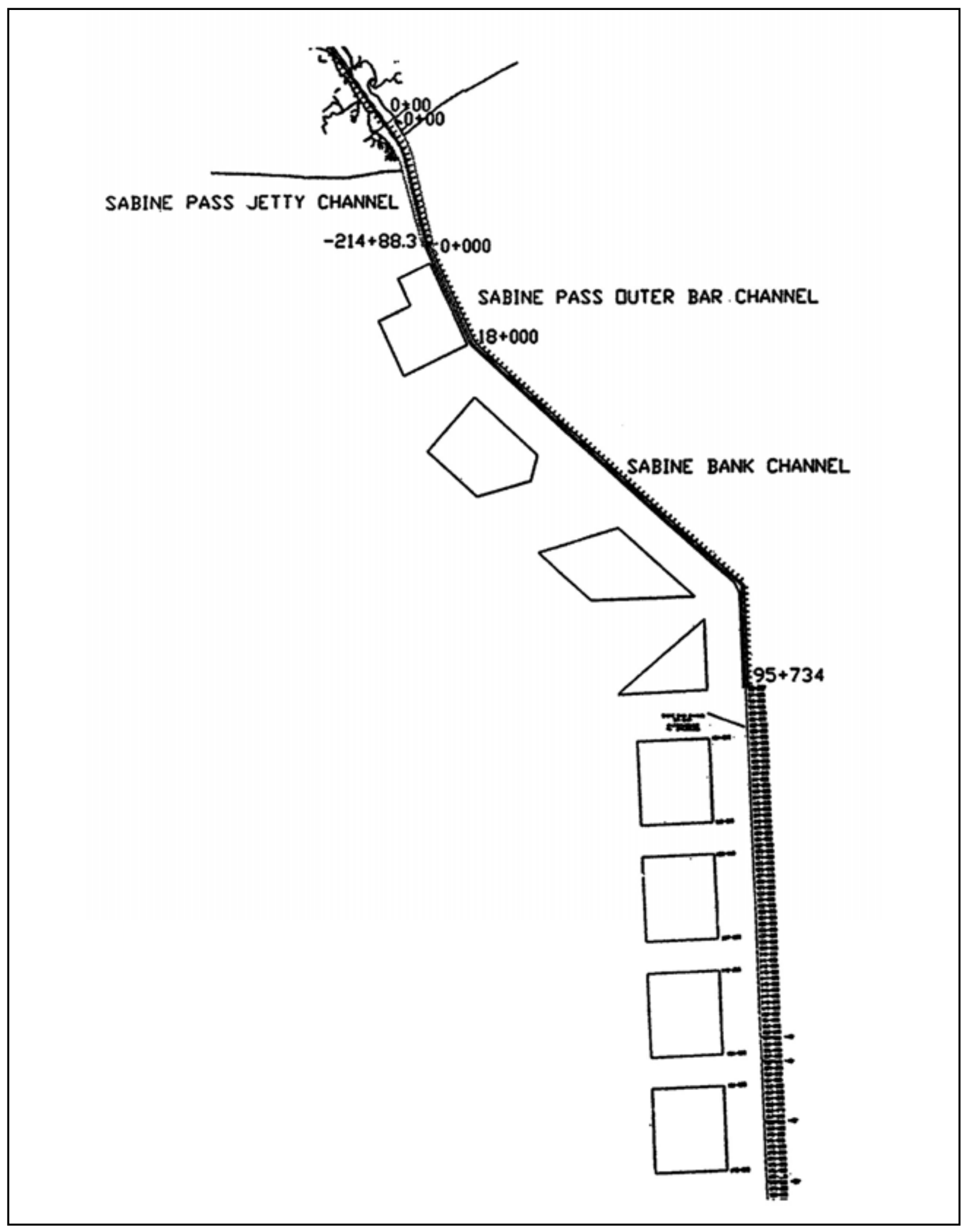

Figure 4. Sabine Neches, TX, outer navigation channel 
A typical cross section of a navigation channel and related parameters are shown in Figure 5. Little shoaling occurs when flow is along the length of channel and flow velocities are of sufficient strength to prevent deposition of suspended and bed sediments. However, considerable shoaling occurs when the sediment-laden flow is across the channel and flow velocities in the channel are low.

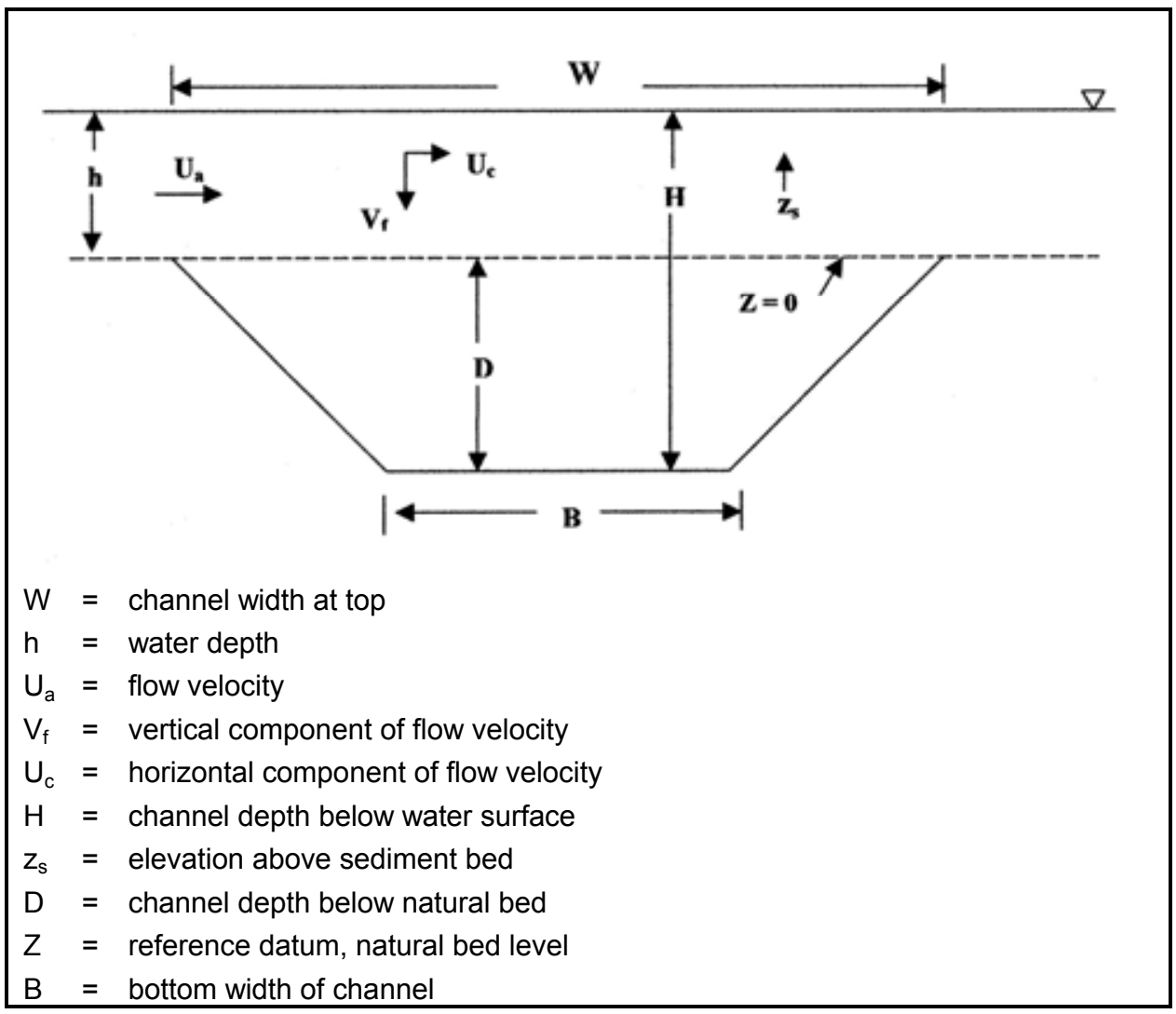

Figure 5. Typical cross section of navigation channel

\section{Reducing Siltation}

\section{Factors to be considered}

It is essential that important physical factors at play be determined before even considering an appropriate method for reducing siltation in harbors and navigation channels. These factors are listed below.

a. Type of sediment.
(1) Cohesive.
(2) Noncohesive.
(3) Mixture.
(4) Fluid mud. 
(5) Calcareous.

(6) Biogenic.

(7) Loam.

(8) Peat.

b. Identification of sediment source.

(1) Suspended sediment.

(2) Bed erosion.

(3) Bank sloughing.

(4) Adjacent land areas.

(5) Sediment recirculation.

(6) Aeolian sediment transport.

(7) Littoral drift.

(8) Flood/ebb shoal.

(9) Porous land reclamation.

(10) Porous other structures.

c. Critical natural parameter involved.

(1) Tidal current.

(2) Ocean influx.

(3) River discharge.

(4) Tributary inflow.

(5) Density current.

(6) Waves.

(7) Vessel-induced waves and currents.

(8) Eddies.

(9) Flow stagnation.

(10) Meandering river.

(11) Geomorphology.

(12) Land runoff.

(13) Sea level rise.

(14) Land upheaval or subsidence.

(15) Over-bank flow.

(16) Existing structures.

(17) Episodic events such as earthquake and storm. 
d. Time scale of shoaling occurrence.
(1) Perennial.
(2) Periodically recurring.
(3) Sporadic.
e. Total volume of sediment.

(1) For selecting suitable dredging equipment.

(2) For working out benefit/cost ratio for proposed measures.

f. Importance of the location.
(1) National defense.
(2) Recreational.
(3) Environmental.
(4) Archeological.
(5) Commercial.

g. Location of major problem.
(1) Specific channel reach.
(2) Berths.
(3) Estuary mouth.

h. Best approach to investigate the problem.

(1) Physical modeling.

(2) Tracer study.

(3) Numerical modeling.

(4) Field data analysis.

(5) Desktop study.

i. Success or failure of measures taken at other sites under similar site conditions and natural parameters.

\section{Potential methods to prevent siltation}

Parchure ${ }^{1}$ identified the following seven methods reported in literature for reducing channel siltation:

- Reduce sediment inflow from the source.

- Prevent sediment from entering the channel.

- Catch sediment before it enters the sensitive area.

1 Parchure, T. M. (2002, Unpublished), "33 ways to reduce shoaling in navigation channels," Technical Note, Coastal and Hydraulics Laboratory, U.S. Army Engineer Research and Development Center, Vicksburg, MS. 
- Divert sediment away from the area of interest.

- Prevent sediment recirculation.

- Prevent/induce sediment deposition.

- Other methods.

The best-suited method for a given project must be thoroughly researched to ensure its efficient functioning for the intended purpose. Sometimes, a combination of various methods may be required.

The seven methods listed above may be classified as either structural methods, nonstructural methods, or management/other methods.

Structural methods include construction of massive and expensive structures such as dikes, bendway weirs, breakwaters, jetties, weir jetties, sediment barriers, sediment traps, channel closing structures, flow diversion structures such as dams and canals, and current deflector walls. Structural methods are the most prevailing and are found to be very effective in reducing channel shoaling. Use of such structures is described in this report along with description of numerous studies and examples of sites where they have been used.

In addition to structural methods, nonstructural methods are also used to reduce navigation channel shoaling. Smits et al. (1994) reported that heavy navigation traffic to and from the locks at Antwerp required the use of alternative dredging techniques such as the use of a sweep beam, which reduces interruption to navigation that results from normal dredging operations. The sweep beam resembles a bulldozer blade that pushes the settled mud back into the river for further natural transport away from the reach of interest. Since dredging occurs almost continuously, the influence of dredging works on the turbidity in the river is limited.

Pettweis and Sas (1999) evaluated possible use of silt screens at Antwerp Harbor and concluded that they were not feasible due to the high possibility of damage to the screen by frequent ship traffic.

\section{Dredging}

Almost all harbors in the world require dredging to create new navigational facilities. Most harbors also require periodic maintenance dredging for removing accumulated sediment from navigable areas. Since dredging operations are expensive, time-consuming, and interfere with navigation, there is a great deal of interest in reducing or minimizing the quantity of dredging. Considerable research and extensive field experience have offered several methods to achieve this objective.

Quantities and costs of total and maintenance dredging carried out in the United States over the past few years are given in Table 1. The average maintenance dredging cost was about $\$ 500$ million per year, which constituted 86 percent of the total dredging quantity and 75 percent of the total dredging cost. 


\begin{tabular}{|c|c|c|c|c|c|c|}
\hline \multicolumn{7}{|c|}{$\begin{array}{l}\text { Table } 1 \\
\text { Quantities and Costs of Dredging (Navigation Data Center 2005) }\end{array}$} \\
\hline Year & $\begin{array}{l}\text { Total Dredging } \\
\text { million cu yd }\end{array}$ & $\begin{array}{l}\text { Maintenance } \\
\text { Dredging } \\
\text { million cu yd } \\
\end{array}$ & $\%$ & $\begin{array}{l}\text { Total } \\
\text { Expenditure } \\
\text { million \$ } \\
\end{array}$ & $\begin{array}{l}\text { Maintenance } \\
\text { Expenditure } \\
\text { million \$ } \\
\end{array}$ & $\%$ \\
\hline 1995 & 251.18 & 217.13 & 86.45 & 531.77 & 408.18 & 76.76 \\
\hline 1996 & 258.64 & 234.27 & 90.58 & 514.77 & 425.02 & 82.57 \\
\hline 1997 & 284.93 & 252.74 & 88.70 & 621.93 & 494.45 & 79.50 \\
\hline 1998 & 238.78 & 211.31 & 88.50 & 712.57 & 532.47 & 74.73 \\
\hline 1999 & 284.06 & 241.74 & 85.10 & 815.93 & 580.13 & 71.10 \\
\hline 2000 & 285.33 & 226.70 & 79.45 & 821.68 & 540.99 & 65.84 \\
\hline Avg. & & 230.65 & 86.46 & & 496.85 & 75.08 \\
\hline
\end{tabular}

Different dredging equipment and techniques need to be used under the varying site conditions. Location of the dredged material placement site is also an important factor in selecting the type of dredging equipment. Due to varying site conditions, shoaling along navigation channels is never uniform. As an illustration, quantities of dredging in various sections of Sabine Neches and Georgetown Harbor, SC, navigation channels are presented in the following paragraphs.

Zones of major siltation experienced along the navigation channel of Georgetown Harbor are shown in Figure 6. Average annual quantities of dredging in these four zones are as follows:

Zone 1: Upper Harbor

Zone 2: Frazier Point

Zone 3: Winyah Bay

Zone 4: Lower Winyah Bay
822,000 cu yd

$451,000 \mathrm{cu}$ yd

250,000 cu yd

750,000 cu yd

Total $2,273,000 \mathrm{cu}$ yd

The type of sediment may have a large variation along a navigation channel. For instance, the upper end of the navigation channel at Georgetown Harbor consists of clay; the seaward portion consists of sand; and the reach between these consists of mixtures of sand, silt, and clay in varying proportions. It is noted that the sediment gets finer towards the upper harbor. The layout of the navigation channel from the seaward jetties to the upstream harbor is shown in Figure 7. The composition of bed sediment in the area obtained from the use of limited available data is given in Table 2 .

The types of dredges include cutter suction, hopper suction, trailing suction, side-cast, bucket, and grab. Hydraulic transport of sediment by pumping slurry through pipes is an effective and faster method of removing sediments from underwater locations and placing them at predetermined sites. Hopper dredges collect a load of dredged sediment in their hoppers, carry it to the disposal site, and empty the load through bottom-opening doors or split hulls. The type of strata to be removed is also an important consideration. Suction dredges can 


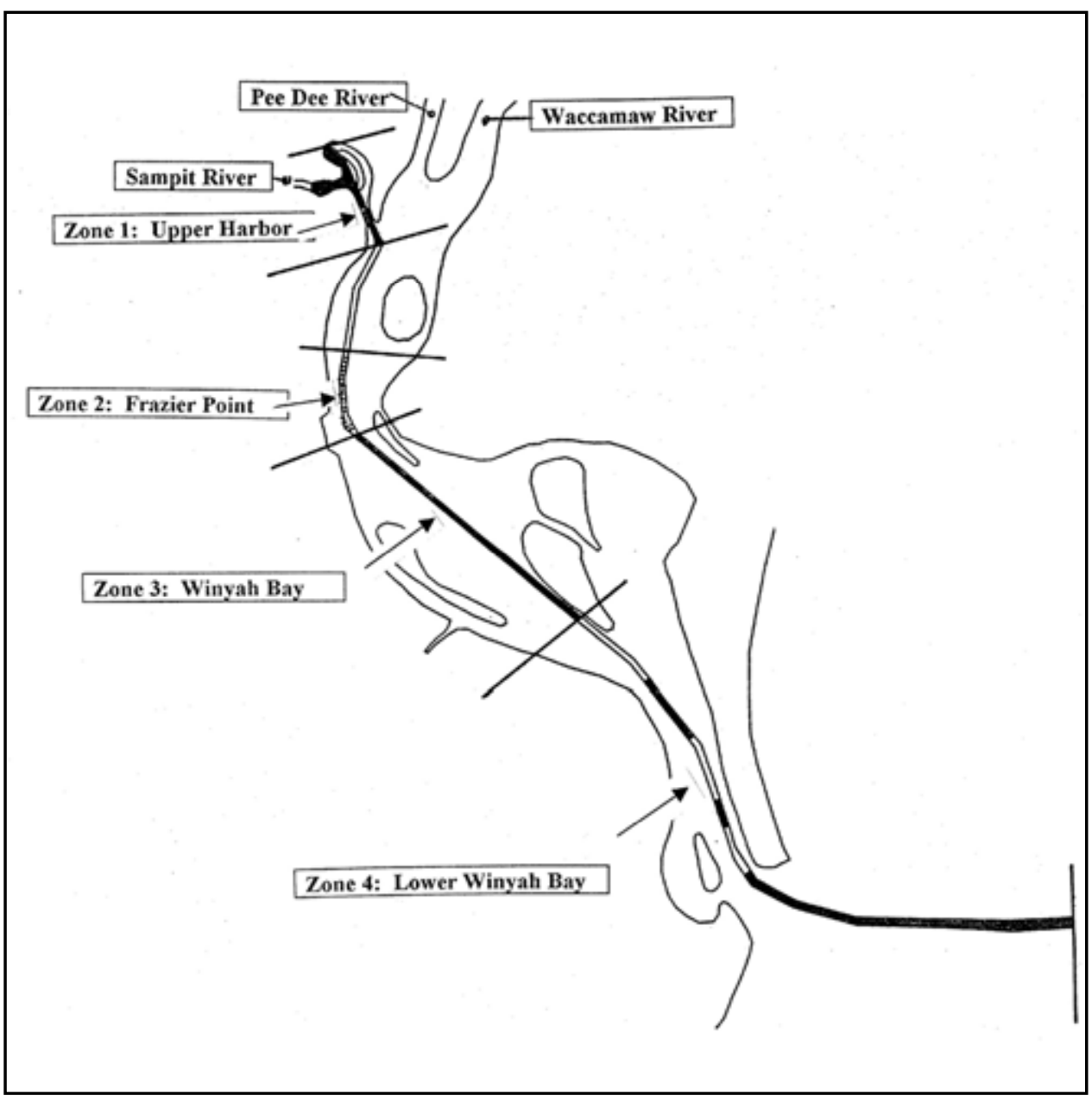

Figure 6. Zones of major siltation in Georgetown Harbor navigation channel

remove and pump a slurry of sand and silt easily, whereas stiff sediments with high quantities of clays require cutters. Rock dredging requires chisels and use of explosives.

Agitation dredging consists of churning the sediment locally at the location of the dredge and allowing the sediment to move away with the natural current as suspended load. Everts (1976) studied shoaling patterns and natural conditions at Dillingham Harbor, AK, and concluded as follows.

Although agitation dredging is not a recommended practice in most areas because of environmental as well as engineering considerations, it might be feasible in a region such as Nushagak Bay. As a result of the direct high ambient suspended sediment concentrations and thorough mixing, direct discharge to the Bay by resuspension in the basin during an ebbing tide may be an acceptable alternative to hydraulic dredging. Agitation dredging would neither increase Bay concentrations nor be environmentally undesirable. Also, little of the discharged sediment would return to the Harbor at a later time. 


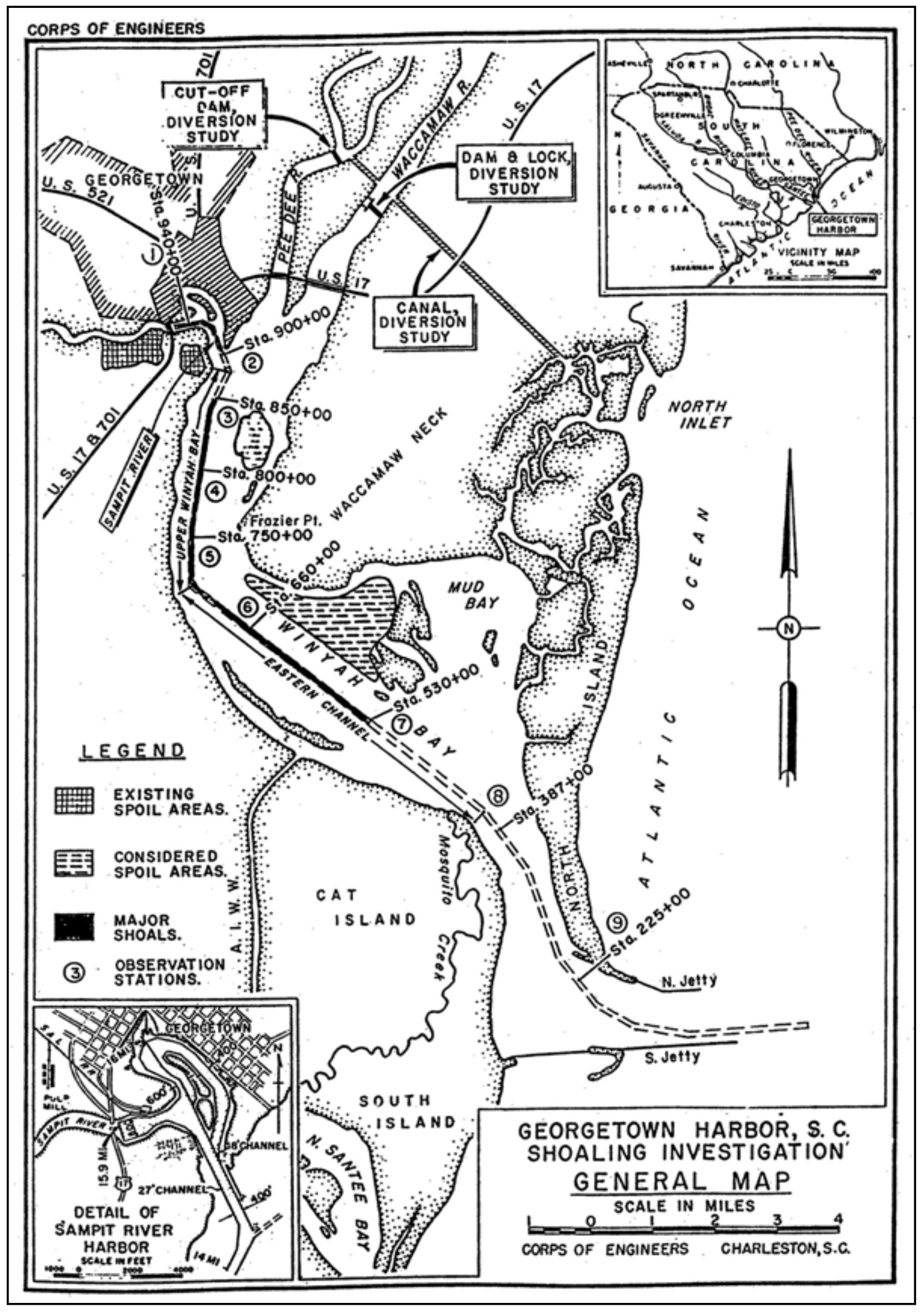

Figure 7. Georgetown Harbor navigation channel 


\begin{tabular}{|c|c|c|c|}
\hline \multicolumn{4}{|c|}{$\begin{array}{l}\text { Table } 2 \\
\text { Bed Sediment Variation Along the Navigation Channel at } \\
\text { Georgetown Harbor }\end{array}$} \\
\hline & Clay, \% & Silt, \% & Sand, \% \\
\hline Outer channel & & & 100 \\
\hline Near the estuary mouth & 10 & & 90 \\
\hline Entrance channel & & & 100 \\
\hline South of Frazier Point & 40 & 50 & 10 \\
\hline Vicinity of Frazier Point & 30 & 65 & 5 \\
\hline Near Rabbit Island & 50 & 35 & 15 \\
\hline North of Rabbit Island & 20 & 75 & 5 \\
\hline Harbor area, western arm & 45 & 45 & 10 \\
\hline Harbor area, northern arm & 25 & 75 & \\
\hline
\end{tabular}

Dredging frequency. The frequency of dredging is based on both hydrographic surveys indicating loss of water depth due to shoaling and past experience. Shoaling rates along a long navigation channel are often quite different, which requires different dredging frequencies. In addition to routine maintenance dredging, out-of-turn emergency dredging is needed to remove sedimentation caused by episodic events such as storms. An illustration of dredging frequencies in different reaches of the navigation channel at Sabine Neches is given in Table 3. It may be seen from Table 3 that dredging frequency varied from once a year to once in 6 years for different reaches of the same channel.

\begin{tabular}{|c|c|c|}
\hline \multicolumn{3}{|c|}{$\begin{array}{l}\text { Table } 3 \\
\text { Maintenance Dredging Frequencies and Shoaling Rates, Sabine } \\
\text { Neches Waterway }\end{array}$} \\
\hline Project Reach & $\begin{array}{l}\text { Frequency } \\
\text { months }\end{array}$ & $\begin{array}{l}\text { Estimate Annual } \\
\text { Shoaling } \\
\text { cu yd }\end{array}$ \\
\hline Sabine bank channel & 12 & $5,400,000$ \\
\hline Sabine Pass jetty \& outer bar channels & 12 & $3,000,000$ \\
\hline Sabine Pass channel & 24 & 500,000 \\
\hline Port Arthur Canal & 24 & $1,000,000$ \\
\hline Port Arthur turning basins & 18 & 500,000 \\
\hline Sabine Neches Canal (upper and lower reaches) & 24 & $1,000,000$ \\
\hline Neches River channel (lower reach) & 24 & $1,000,000$ \\
\hline Neches River channel (middle reach) & 36 & 500,000 \\
\hline Neches River channel (upper reach) & $60-72$ & 200,000 \\
\hline Sabine Neches Canal (Sec. "B") N.R. to S.R. & $24-48$ & 400,000 \\
\hline Sabine River channel & 36 & 200,000 \\
\hline
\end{tabular}


Dredging constraints. Wide and deep areas of navigation channels and turning basins are easy to dredge. Dredging operations in restricted spaces such as near jetties, berths, and marinas are difficult, time-consuming, and hazardous, and may require different types of dredging equipment. The presence of contaminated sediments also poses severe restrictions on dredging and placement operations.

\section{Sediment types}

Sediments in natural environments cover a wide range of sizes from boulders to clays. According to standard particle-size nomenclature, these sizes include boulder, pebble, coarse sand, fine sand, coarse silt, fine silt, clay, etc. Based on their fundamental properties, sediments may be classified into two groups: noncohesive and cohesive sediments. Clay particles, which are typically smaller than $4 \mu$ in size, are cohesive sediments. The shape of clay particles resembles platelets and their surfaces have a negative charge. The specific surface (surface area per unit weight) is high for clays; they have electro-chemical properties and cation exchange capacity. Therefore, clays behave very differently in water than noncohesive sediments. Clay particles clump together in various orders of aggregation to form flocks of varying sizes and densities. Instead of individual particles, these flocks settle to the bed. Noncohesive sediment particles, however, settle individually. These and other fundamental differences need to be considered when estimating shoaling of navigation channels. Natural sediments usually consist of mixtures of sand, silt, clays, and organic substances in varying proportions and are also called "mud." Most of the shorelines in the world have noncohesive sediment (sand), whereas most of the estuaries consist of cohesive sediments. Extensive laboratory testing is needed to adequately characterize properties of muds.

\section{Sediment transport}

Sediments are transported as bed load, suspended load, or wash load. Coarse sediments such as sand and pebble are transported primarily as bed load because the flow characteristics often do not provide conditions favorable to keep them in suspension for an extended period of time. Fine to coarse sand is transported as suspended load. Silt and clay particles often travel as wash load. Wash load consists of small-size sediment particles that are not found in the bed sediment because they remain in suspension. Mathematical expressions describing transport are quite different for cohesive and non-cohesive sediment sand for bed load and wash load.

\section{Fluid mud}

Under certain special circumstances, fine sediments form "fluid mud" in the natural environment. It consists of a thick, viscous suspension of fine sediments in the water column, which does not settle readily to form a sediment bed. Presence of fluid mud causes interference in the navigation of vessels and is difficult to dredge. The mechanism of formation of fluid mud and its properties 
are yet to be fully understood. Therefore, measures to eliminate fluid mud from natural sites have not been developed.

\section{Sediment source}

While considering ways to reduce shoaling in a navigation channel, it is essential to identify the source of sediment responsible for the problem at the site. Various sources of sediment are listed in Chapter 1; however, it is not always easy to identify the sediment source. Pettweis and Sas (1999) conducted numerical model studies on sedimentation of mud in the access channels of the harbor of Antwerp, Belgium. They identified three major processes of mud deposition in these navigation channels: density flow, eddy formation in the dock area, and tidal filling.

\section{Sedimentary processes and human interference}

Sediment in the natural environment occurs on banks and beds and also in suspension in the water column. Sediment may be suspended in water when waves, wind, and current dislodge it from the bed or banks. Suspended sediment deposits when the available energy is less than that needed to keep it suspended against the force of gravity. Equations are available to calculate wave- and windinduced shear stresses that may be the relevant forcing functions at sites under study.

There are a few similarities and several significant differences in the depositional processes of noncohesive and cohesive sediments. The movement of fine sediment in an estuary can be considered as a cycle of four processes: erosion, transport in suspension, deposition, and bed consolidation. Since each of these processes is a complex and not well-defined function of both the flow properties and sediment characteristics, empirical expressions have to be used to describe the relationship mathematically. Laboratory and field experiments are necessary to determine the constants in these expressions. Wicker and Eaton (1965) have described sedimentation in tidal waterways. Mehta (1986) has described the estuarine transport processes in detail.

The natural sedimentary processes undergo changes resulting from human interference. Several measures can be taken with the objective of reducing shoaling in harbors and navigation channels. These are based on past experience, results of physical or numerical model studies, or analysis of field data. Such measures may be considered as successful if they met the intended objective, or they may be considered as a failure if the intended objectives were not met. Either way, such actions provide valuable lessons to both the design engineers and practicing engineers. The most valuable lessons are learned from the designed projects that were constructed and monitored over a period of time to permit meaningful evaluation. A little less valuable are the cases where laboratory and field studies were conducted on the proposed actions, but the projects were either not constructed or not monitored. The conclusions of the design studies are still quite useful. 
This report offers examples of success and failure of a variety of structures proposed or constructed for reducing channel and harbor shoaling. It is important to note that measures that have been highly successful at one project may not be useful at all at some other project due to different site conditions, environmental parameters, availability of construction materials, cost, etc. Some projects require adoption of multiple measures to overcome the shoaling problem.

\section{Significance of sediments}

The type of sediments and their mode of transport are important factors that need to be taken into account while designing structures to reduce channel shoaling. Barriers such as jetties and breakwaters are effective in arresting coarse sediment such as sand, which is primarily transported as bed load; however, they are not efficient in arresting suspended sediments. Sedimentation or erosion of fine sediments can be induced more easily by modifying hydraulic conditions at the site than by placing structures. 


\section{River Training Structures}

Dikes are effective at confining the river in a single channel, with the goal of providing depths suitable for commercial navigation at the full range of expected flows. Also, the use of dikes minimizes or eliminates dredging for channel maintenance. Channel dredging is only a temporary measure, and dikes can significantly reduce the need for maintenance dredging. Dikes function continually at all river stages and concentrate the river's energy into a single channel to control the location and depth of the navigation channel and impact the erosional and depositional characteristics of the river. Dikes have been known by a variety of names such as groins, contracting dikes, transverse dikes, cross dikes, spur dikes, spur dams, cross dams, wing dams, spurs, and jetties. All of these typically apply to a river training structure that is approximately normal to the riverbank, is attached to the riverbank, and contracts the natural river channel but does not transverse the entire river channel. Other types of river training structures include kicker dikes, tie-in dikes, longitudinal dikes, L-head dikes, vane dikes, trail dikes, transverse dikes, and bendway weirs or submerged sills. A variety of dikes have been used on innumerable projects all over the world. Some of these types of dikes are briefly described below.

\section{Spur Dikes and Wing Dikes}

A spur dike is defined as a structure placed approximately perpendicular to the bank line to concentrate the flow into a single channel. A schematic layout of spur dikes is shown in Figure 8. The design of spur dikes must consider parameters such as channel alignment, contraction, dike length, dike height, crest width, side slopes, end slopes, dike angle, dike spacing, stone size, bank paving, and method of construction. At a given cross section, dike length is the major parameter that controls the amount of channel contraction, while the dike height and crest profile impact the stability of the dike system.

Wing dike is just another name for spur dike. Wing dikes have been successful in reducing the amount of shoaling and dredging frequency in lower approaches on the Arkansas River. Use of two wing dikes was successful in reducing the amount and frequency of dredging at the Smithland Locks and Dam located on the Ohio River at river mile 918.5. 


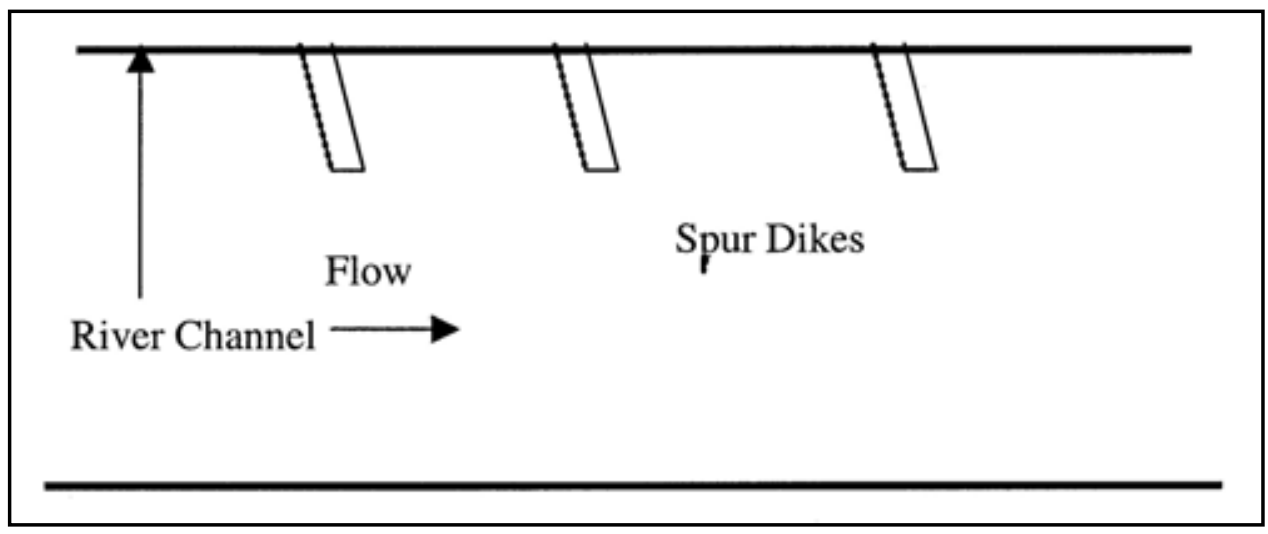

Figure 8. Schematic layout of spur dikes

\section{Vane Dikes}

Dikes placed in the form of a series of vanes have proved effective as a means of controlling channel development and sediment movement under certain conditions. A schematic layout of vane dikes is shown in Figure 9. These dikes consist of segments of dikes located riverward from the existing bank with gaps between the dikes. The length of the gaps between the dikes is usually about 50 to 60 percent of the length of each vane. Usually, all vanes in a system are of equal length. The dikes are placed at a slight angle to the direction of flow, about 10 to $15 \mathrm{deg}$, with the downstream end of the dike farther riverward than the upstream end. The system should be placed in an area where there is or will be movement of sediment. These dikes have been used on the major navigable rivers in the United States as independent systems or in conjunction with spur dike systems. Vane dikes are often less expensive than conventional dikes since they can be placed in relatively shallow water aligned generally parallel to the channel control line and produce little disturbance to the streamflow. On some of the vane dike systems that have been in place for many years some vanes have been connected to the bank line with a spur dike, creating an L-head dike. This modification was undertaken after significant shoaling of material between the vanes and the area landward of the dikes had taken place.

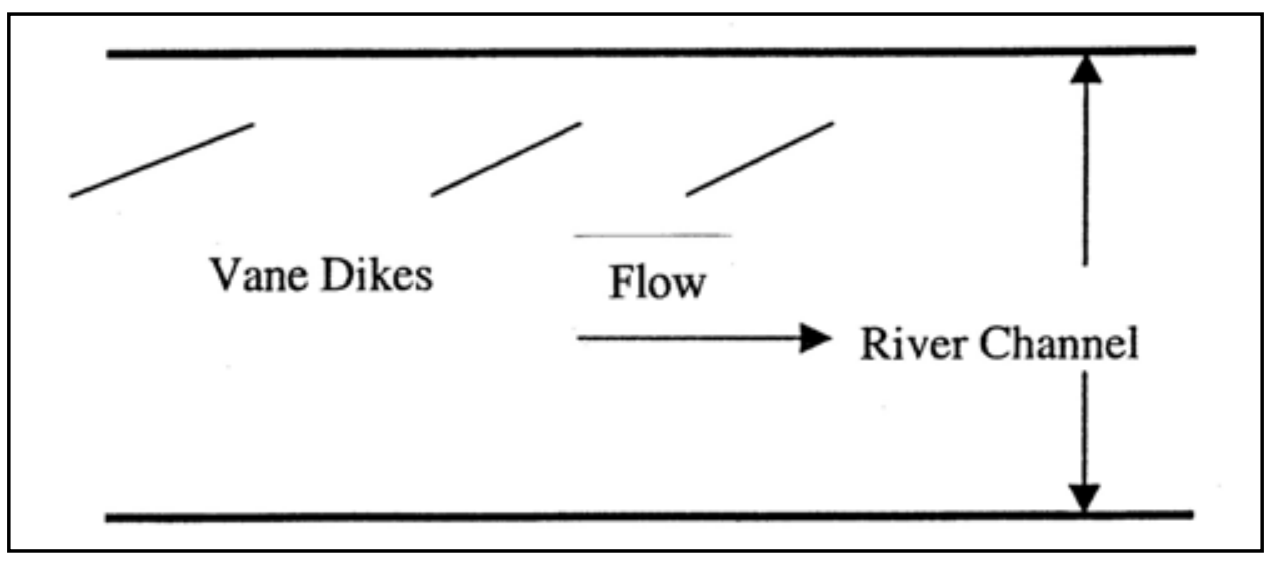

Figure 9. Schematic layout of vane dikes 


\section{Longitudinal Dikes}

Longitudinal dikes are continuous structures extending from the bank downstream generally parallel to the alignment of the channel being developed. A schematic layout of a longitudinal dike is shown in Figure 10. Properly designed longitudinal dikes are the most effective type of structure in developing a stable channel since such structures are basically a false bank line; however, these structures are the most expensive to construct due to their long length and required tiein or baffle dikes. Longitudinal dikes can be used to reduce the curvature of sharp bends and to provide transitions with little resistance or disturbance to flow.

However, once in place, it is difficult and expensive to change the alignment of the dike. It should be noted that the tie-in or anchor dikes landward of the longitudinal dike add stability to the entire structure.

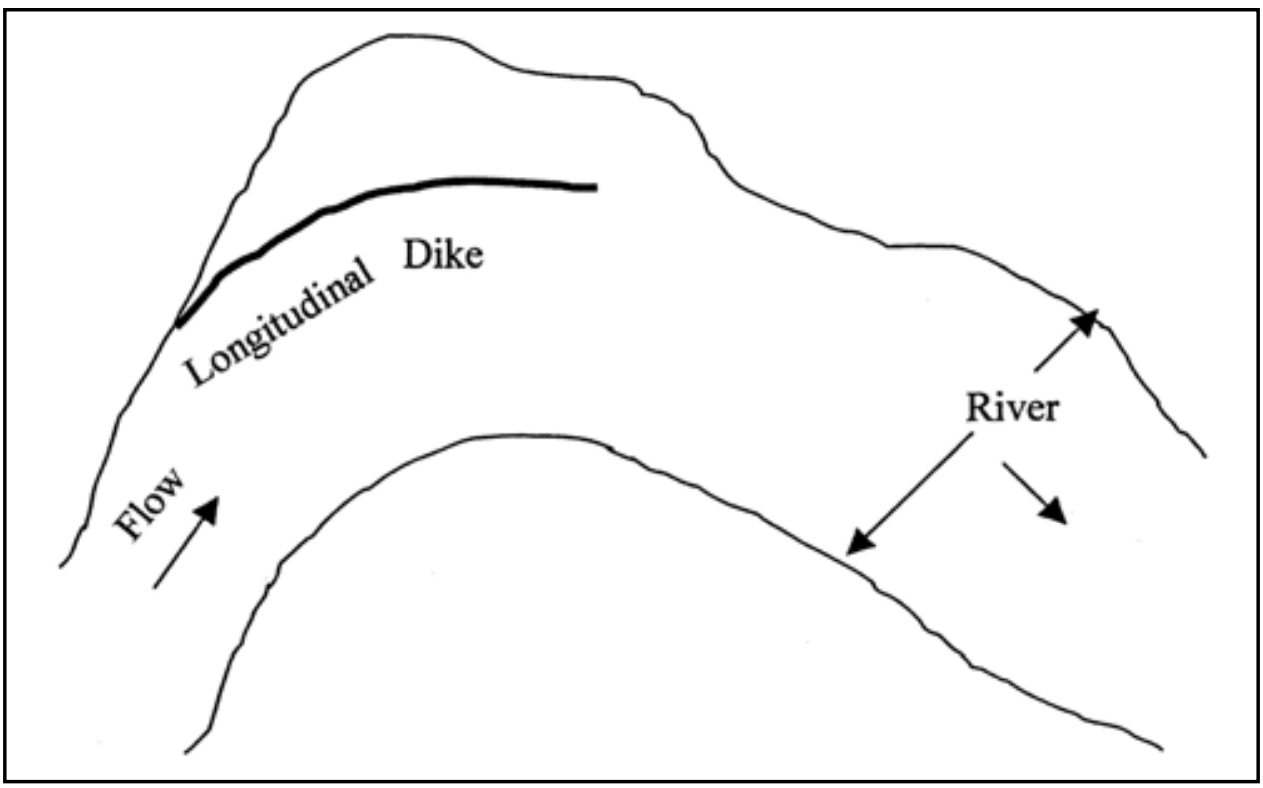

Figure 10. Schematic layout of a longitudinal dike

\section{L-Head Dikes}

L-head dikes are spur dikes with a section extending downstream from the channel ends generally parallel to the channel line. A schematic layout of L-head dikes is shown in Figure 11. The addition of the L-head section can be used to reduce the spacing between spur dikes, to reduce scour on the stream end of the spur dike, or to extend the effects of the spur dike system farther downstream. L-heads dikes tend to block the movement of sediment behind the spur dike. When the L-head crest is lower in elevation than the spur dike crest, surface currents coming over the top of the L-head can cause scour on the landward side. L-head dikes have also been used to reduce shoaling in harbor entrances or to maintain an opening in the downstream end of a bypass channel. Use of L-head dikes is sometimes quite effective and also offers cost reduction due to the significantly lower quantity of stone require to construct the L-head dikes versus a longitudinal dike. 


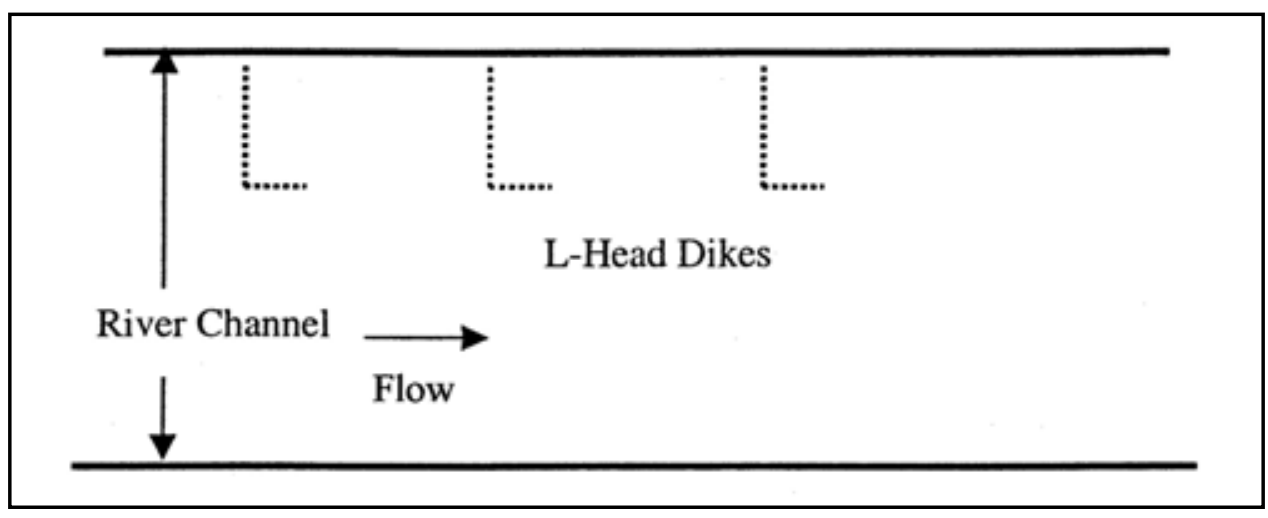

Figure 11. Schematic layout of L-head dikes

Flow over the top of an L-head dike would tend to produce scouring along the entrance side, which would remove any material that may have been deposited during lower flows. An L-head dike structure has been successful in eliminating most of the shoaling in the lower entrance to the Chain of Rocks Canal in the Mississippi River during flows that overtop the structure.

\section{Closure Dikes}

An example of a closure dike is shown in Figure 12. River reaches that include islands and divided flow tend to have limited depths in part due to the loss of energy through the secondary channel. In the past, such cases were modified by reducing or eliminating the low and medium flows from all but the main channel being developed for navigation. This was accomplished by diverting sediment into the side channels or constructing closure structures across the side channels. Sediment could be diverted into the side channel using spur dikes, vane dikes, or a combination of both. Within the secondary channel the closure dikes will further reduce the velocities in the channel and enhance the depositional tendencies in that channel. When the length of the side channel is short relative to that of the main channel, as is the case in a bendway, closure dikes across the secondary channel tend to be difficult to maintain because of the high head differential that develops across the dike and the subsequent scour downstream of the dike. In such cases, closure structures in the secondary channel should have at least two dikes. With the dikes constructed at successively lower elevation moving downstream, the total drop in the secondary channel will be divided between structures, which will reduce the amount of scour that would tend to endanger a single structure.

\section{Anchor Dikes}

A schematic layout of anchor dikes is shown in Figure 13. These dikes connect the main dike to the riverbank and offer protection to the main dike, particularly at high water stages. The anchor dikes can be modified using notches or openings to enhance the habitat and maintain open water areas on the back side of the longitudinal dike. 


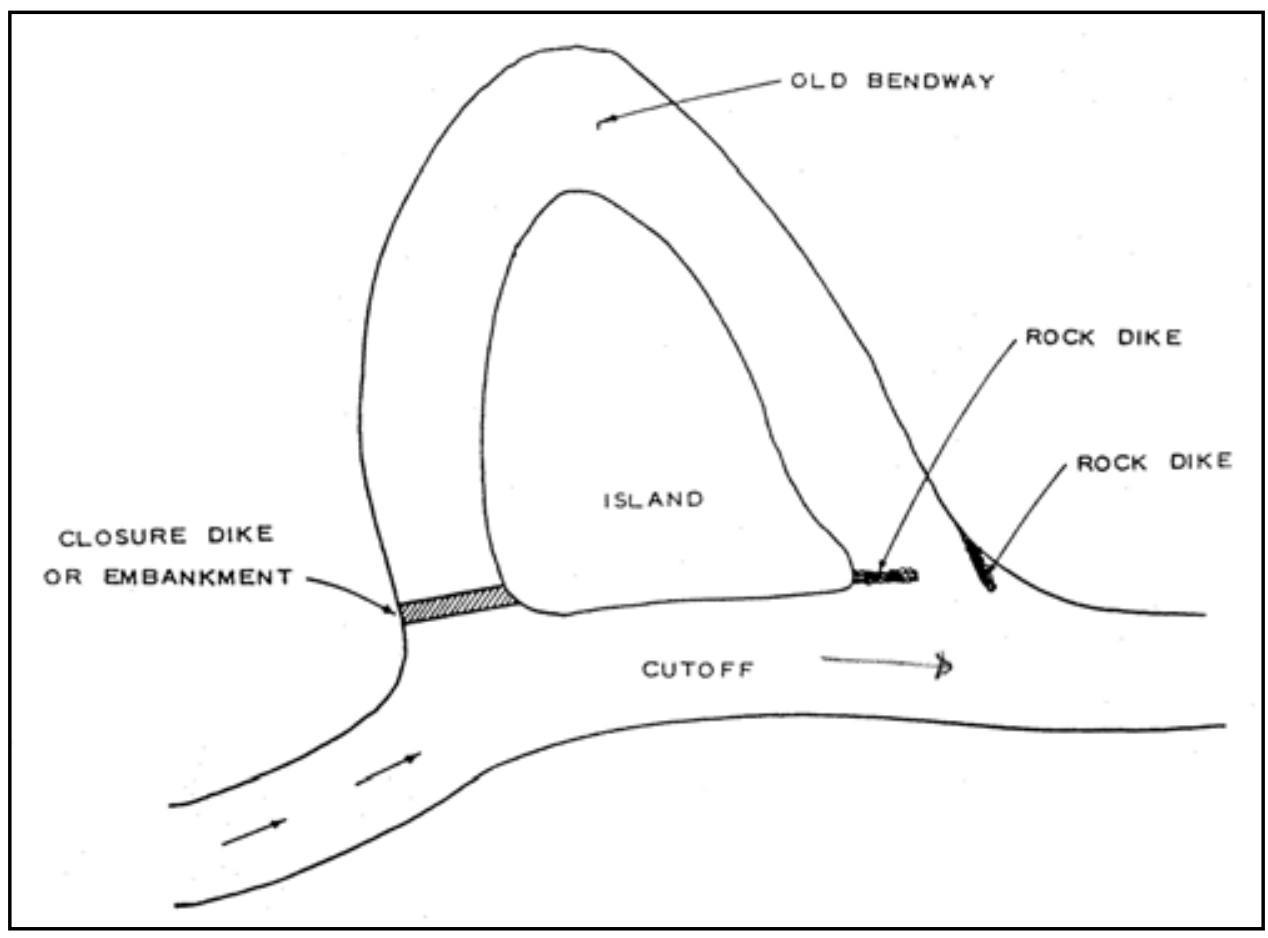

Figure 12. Schematic layout of closure dikes

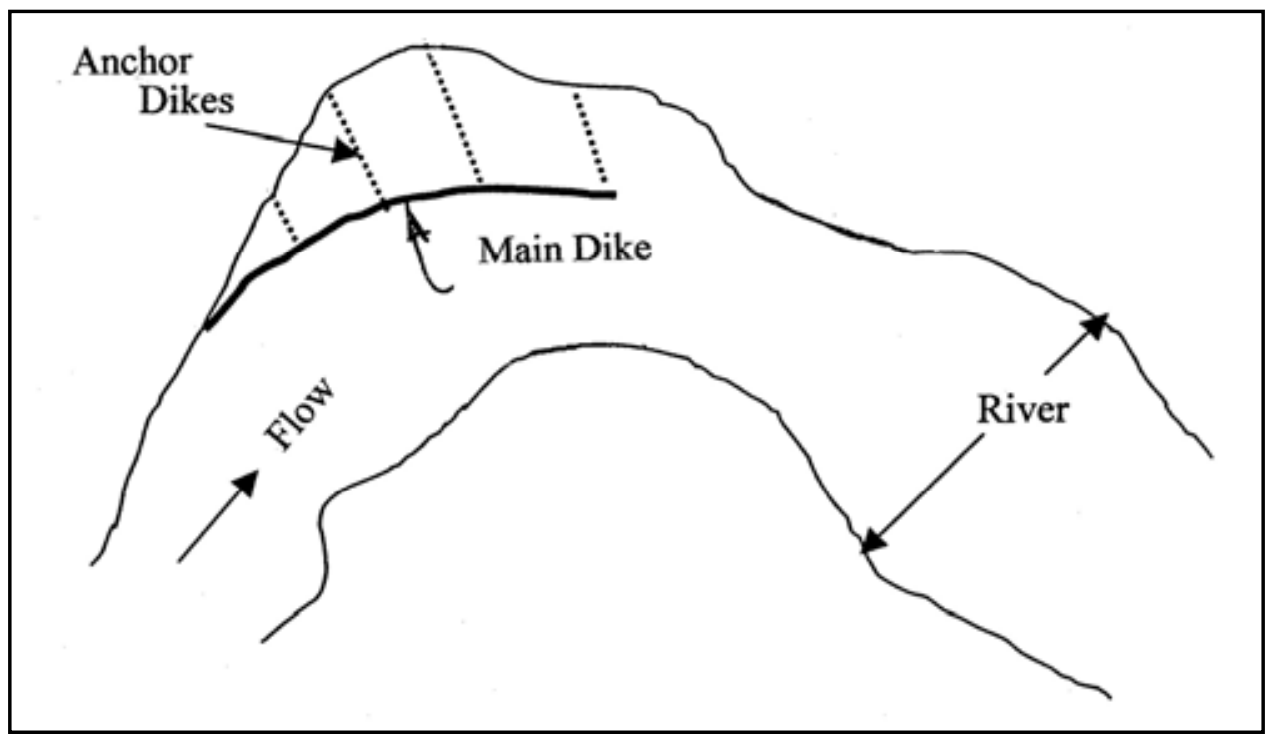

Figure 13. Schematic layout of anchor dikes

\section{Bendway Weirs}

A bendway weir is defined as a rock structure located in the navigation channel of a bend, angled at about 30 deg upstream of a line drawn perpendicular to the bank line at the bank end of the weir. A schematic layout of bendway weirs is shown in Figure 14. A bendway weir is level-crested at an elevation low enough to allow normal river traffic to pass unimpeded over the weir. The weir 


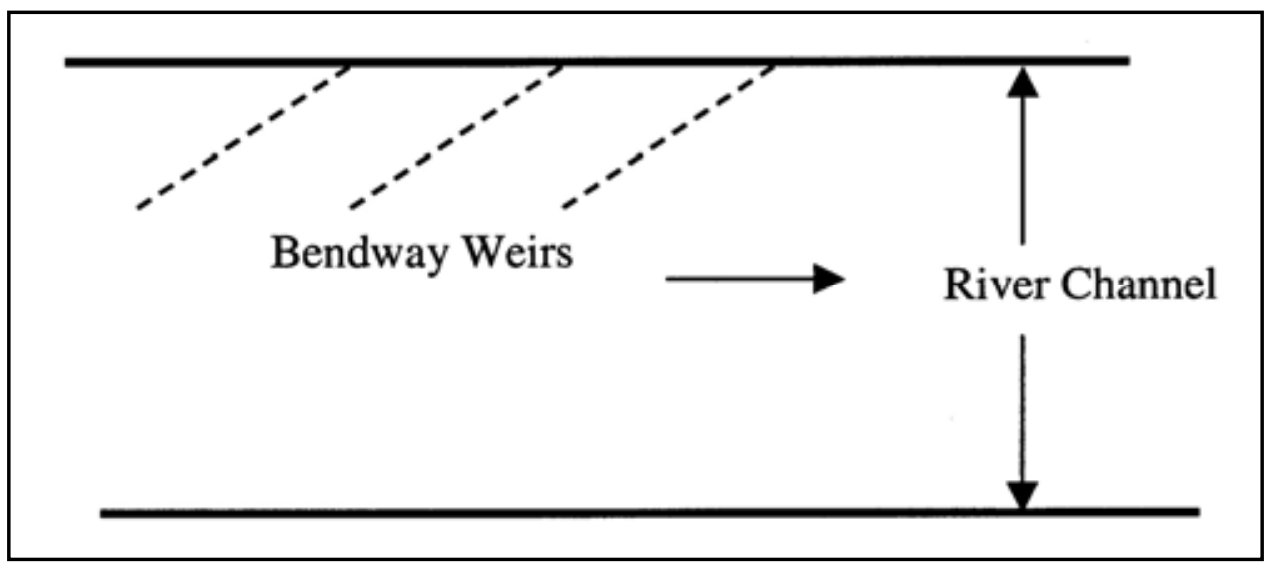

Figure 14. Schematic layout of submerged bendway weirs

must be of adequate height and length to intercept a large enough percentage of flow at the river cross section where the weir is located to produce several hydraulic improvements. Derrick et al. (1994) described the design and development of bendway weirs for the Dogtooth Bend reach of the Mississippi River (Figure 15), which were found to be effective where many types of river training structures were not successful. 


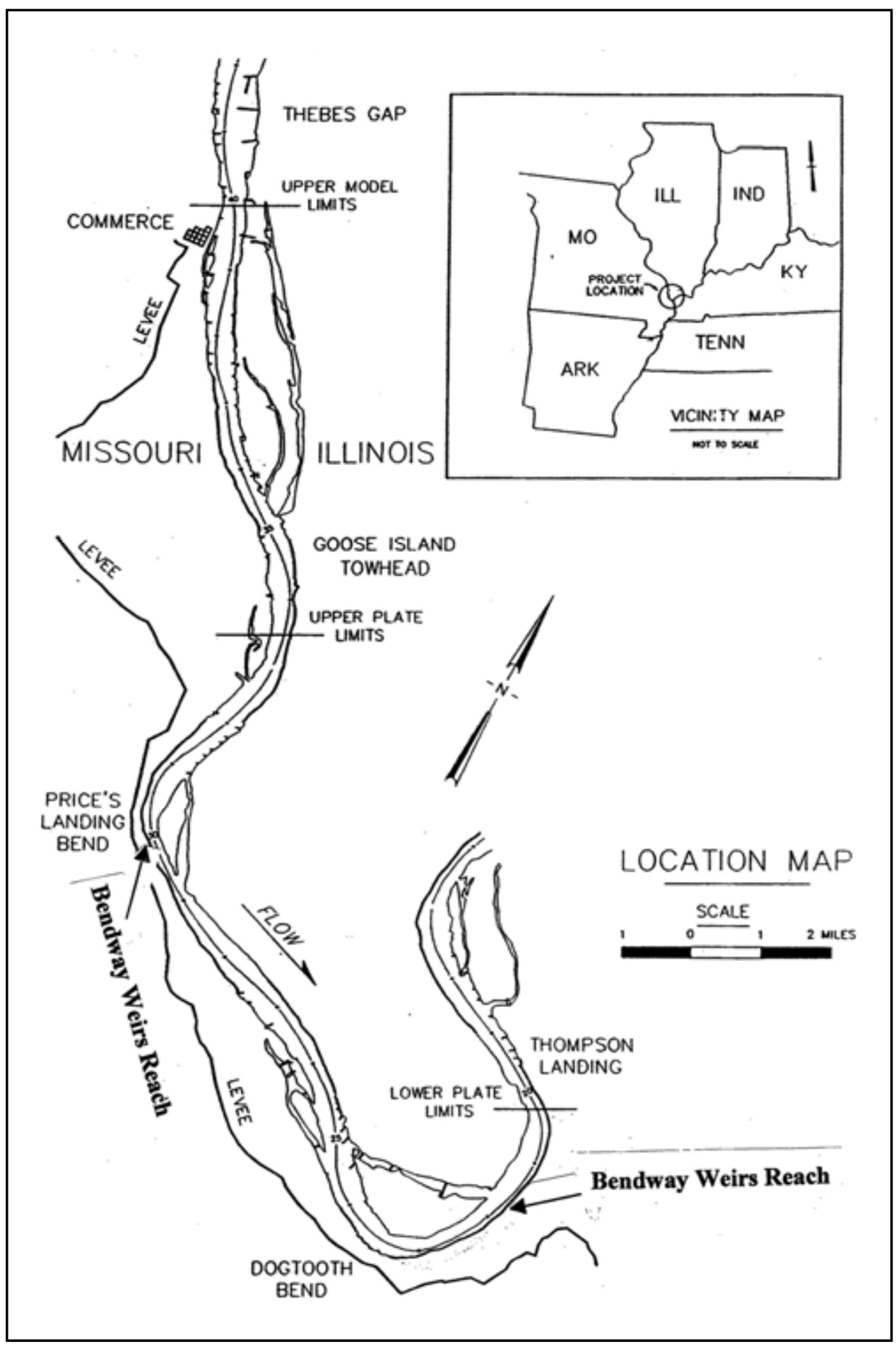

Figure 15. Dogtooth Bend reach of Mississippi River 


\section{Project Examples}

\section{Delaware City Channel}

The Tidewater Oil Company, Delaware Refinery, at Delaware City explored the possibility of reducing shoaling at their facility. Six plans were developed consisting of dikes and two locations of sand traps. Bobb (1965) reported the results of hydraulic model investigations of these plans. It was concluded that all the plans tested had an adverse effect on total shoaling in the company channels. If the plans were implemented, total shoaling was expected to increase by amounts varying between about 55,000 and 475,000 cu yd/year, depending upon the plan.

\section{Mississippi River}

A physical model study using spur dikes and vane dikes together was conducted at the U.S. Army Engineer Waterways Experiment Station (WES), Vicksburg, MS, to determine the effectiveness of dike systems proposed for improvement of troublesome reaches on the Mississippi River (Franco et al. 1970). The purpose of the study was to determine the effectiveness of a proposed dike system and the effectiveness of alternate systems using vane dikes and combinations of vane and spur dikes. The report describes and gives the results of tests concerned with the development of plans for the improvement of the Baleshed-Ajax Bar reach of the river, which is located about 485 river miles above Head of Passes, LA. A movable-bed model reproducing approximately 18 miles of the Mississippi River to a horizontal scale of 1:600 and a vertical scale of 1:60 was used. Several improvement plans involving use of vane dikes and/or spur dikes were tested. In general, results obtained indicated that a satisfactory navigation channel could be developed along the proposed alignment using either vane or spur dikes.

Results of the model study included the following:

a. Limitations of the model adjustment and the effects of the high distortion of the linear scales should be considered in evaluating the results of the test of the Baleshed-Ajax Bar reach. The model channel developed during the adjustment was shallower than that shown by the prototype surveys, and some of the elevations of the sandbar were reduced. Depths developed during the tests of improvement plans should be based on the changes caused by these plans compared with those reproduced in the 
model during the adjustment test. It should also be considered that the model does not reproduce the movement of material in suspension, and no attempt was made to reproduce the degree of erodibility of the banks and sandbars. The tests were conducted with an average hydrograph; use of different hydrographs might have produced somewhat different results.

$b$. In general, the results obtained during the study of this reach indicated that a satisfactory channel could be developed along the proposed alignment with vane or spur dikes. Since spur dikes are generally impermeable, they provide a greater degree of contraction and would tend to produce a deeper channel than vane dikes using the same control channel width. In a relatively long straight reach such as the one developed with the plans tested, there will be a tendency for the channel to meander within the control limits. There will be a greater tendency for the channel to meander toward the spur dikes because of the scouring near the ends of the dikes.

c. Combining vane and spur dikes as tested did not produce very good results. Spur dikes placed downstream of a series of vane dikes caused the vane dikes to lose their effectiveness in diverting sediment landward.

Also, with a spur place downstream of the vane dikes, flow moving into the area behind the dikes through the spaces between the vane dikes was diverted back toward the main channel by the spur dike. This effect would tend to be worse with an increase in the number of vane dikes upstream of the spur dike. There is a need for further study before any definite conclusions can be reached with regard to the use of spur dikes downstream of a series of vane dikes. It would appear from the tests completed that spur dikes placed downstream of vane dikes should be placed at an elevation considerably lower than that of the vane dikes. The elevation of the spur dikes would probably depend on the number of vane dikes, spacing, amount of fill behind the vanes, and flow conditions in the reach.

\section{Arkansas River}

Lock and Dam 13 is located at river mile 292.8 on the Arkansas River. The dam was designed to provide a minimum depth of $9 \mathrm{ft}$ to Lock and Dam 14 at river mile 319.7. Following initial operation of Lock and Dam 14 in January 1971, shoaling in the upstream end of Lock and Dam 13 Pool became a chronic problem, occurring each time flows exceeded 50,000 cfs. In the reach from Lock and Dam 14 to Fort Smith, about 1,864,000 cu yd was dredged in 1971 and $1,273,000 \mathrm{cu}$ yd in 1972 . The higher flows moved large quantities of sediment through the spillway into the area just below the dam; subsequent low flows moved this sediment into the navigation channel just downstream of the lock entrance. Rock in the channel downstream of the lock at about $13 \mathrm{ft}$ below normal pool prevented high flows from developing a deeper channel.

A physical movable-bed model study was conducted at WES that had a 1:120 horizontal scale and 1:80 vertical scale (Foster et al. 1983). The objectives of the model study were to: (1) develop a system of channel structures in the reach just downstream of Lock and Dam 14 that would appreciably reduce the required maintenance dredging without significantly increasing water-surface elevations or velocities; (2) determine the effectiveness of overdepth and 
overwidth dredging in delaying the need for required maintenance dredging; and (3) locate the optimum site for two mooring cells upstream of Lock and Dam 14.

The study indicated that a system of dikes developed during this study could considerably reduce the dredging required to maintain a $250-\mathrm{ft}$ channel downstream of Lock and Dam 14. This system reduced the required dredging following a median-year hydrograph by 63 percent and following a high-water hydrograph by 33 percent. This system of dikes developed a dredge-free navigation channel with a minimum width of $175 \mathrm{ft}$ with both the median-year and high-water hydrographs.

Overwidth dredging in addition to the most effective dike plan tested would essentially eliminate the need for dredging to provide a 250 -ft-wide navigation channel following four median-year hydrographs and reduce the quantity of dredging following a high-water hydrograph by more than 50 percent. With initial overwidth dredging, the median-year hydrograph developed a navigation channel that had a minimum width of $200 \mathrm{ft}$ except for a 300 -ft-long section where the channel was only $100 \mathrm{ft}$ wide. The effect of overdepth dredging was found to be about the same as that of overwidth dredging.

\section{Ohio River}

A physical model investigation was conducted (Franco and Pokrefke 1983) at WES for the development of plans for the Smithland Locks and Dam located on the Ohio River at river mile 918.5.

The conclusions of this study were as follows:

a. Normally, shoaling in the lower lock approach could be eliminated or reduced considerably with a wing dike located near the end of the riverside lock wall. However, the typical wing dike that had been successful in other similar structures was not effective with the Smithland Locks. Use of two wing dikes (Figure 16) as developed in this study was successful in reducing the amount and frequency of dredging.

$b$. Developments in the lower reach were affected by divided flow and intermittent flow from the Cumberland River. Dike structures would be required along the right bank downstream of the locks to prevent the channel from meandering and migrating toward the right bank.

c. Navigation conditions in the upper lock approach would be better with the dike along the right side of the approach channel moved at least $50 \mathrm{ft}$ landward of that proposed in the original design and extended upstream at least $700 \mathrm{ft}$. The landward movement of the dike would provide tows additional maneuver area landward of the guard wall, and the upstream extension of the dike would cause flow from the right overbank and Dog Creek to enter the approach channel far enough upstream to reduce its effect on downbound tows moving along the bank line. 


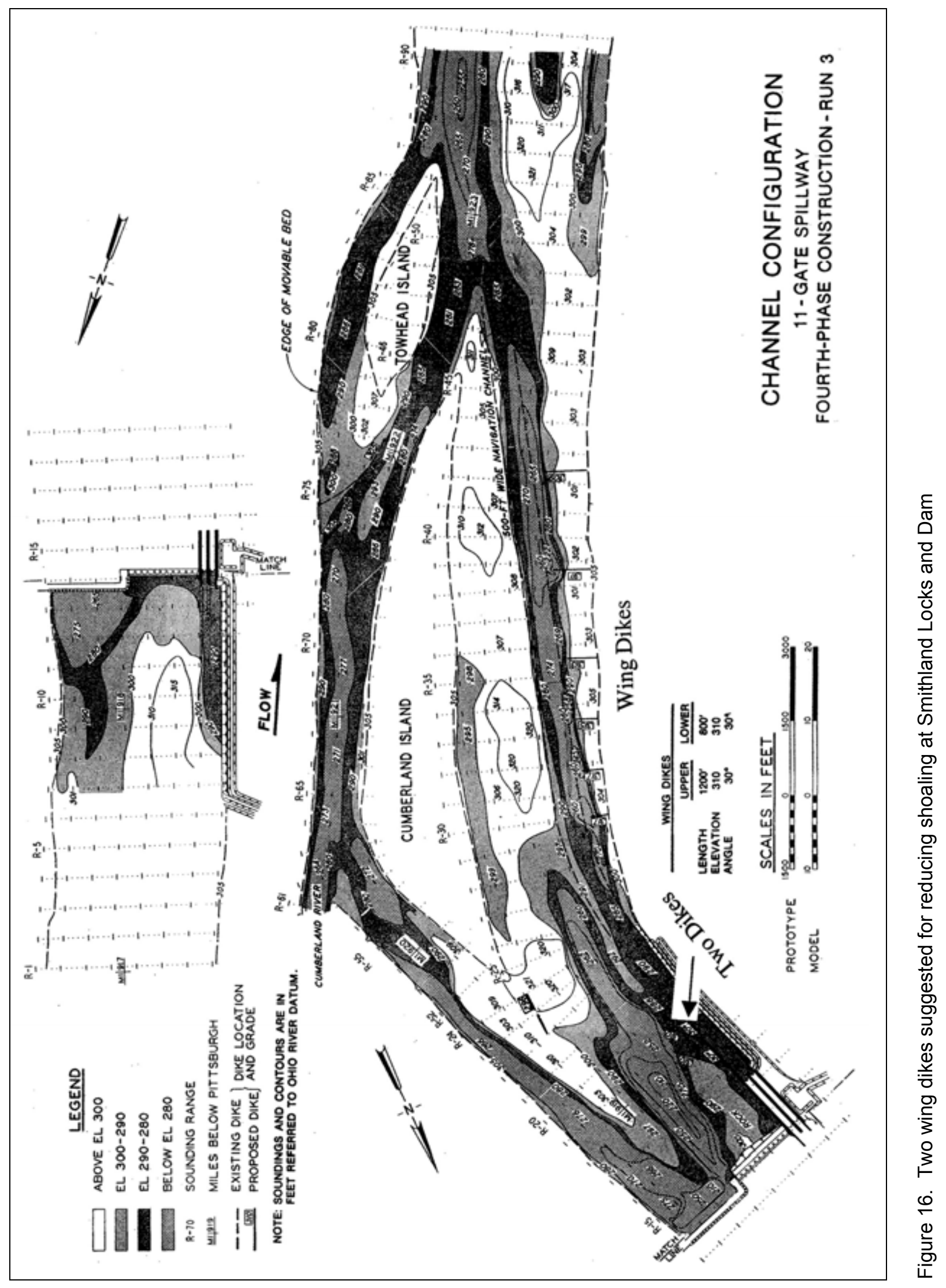




\section{St. Louis Harbor}

St. Louis Harbor, MO, is located on the convex side of a long-radius bend of the Mississippi River, about 15 miles below the mouth of the Missouri River.

Heavy shoaling in the lower entrance to the Chain of Rocks Canal took place. In order to minimize shoaling, a trail dike creating an L-head dike was constructed along the river side of entrance. This dike has been effective in reducing or eliminating shoaling during periods when the dike is overtopped. However, considerable dredging is required during low river stages. A movable model was constructed to horizontal and vertical scales of 1:250 and 1:100, respectively. Crushed coal with a median size of $4 \mathrm{~mm}$ and specific gravity of 1.3 was used for molding the model bed. The model study concluded (Franco 1972) that placing dikes along the right bank just upstream of the entrance to the Chain of Rocks Canal would tend to increase depths along the river side of the dikes and reduce shoaling in the entrance to the canal. The dikes (Figure 17) also resulted in considerable reduction in shoaling along the right bank below the municipal docks. 


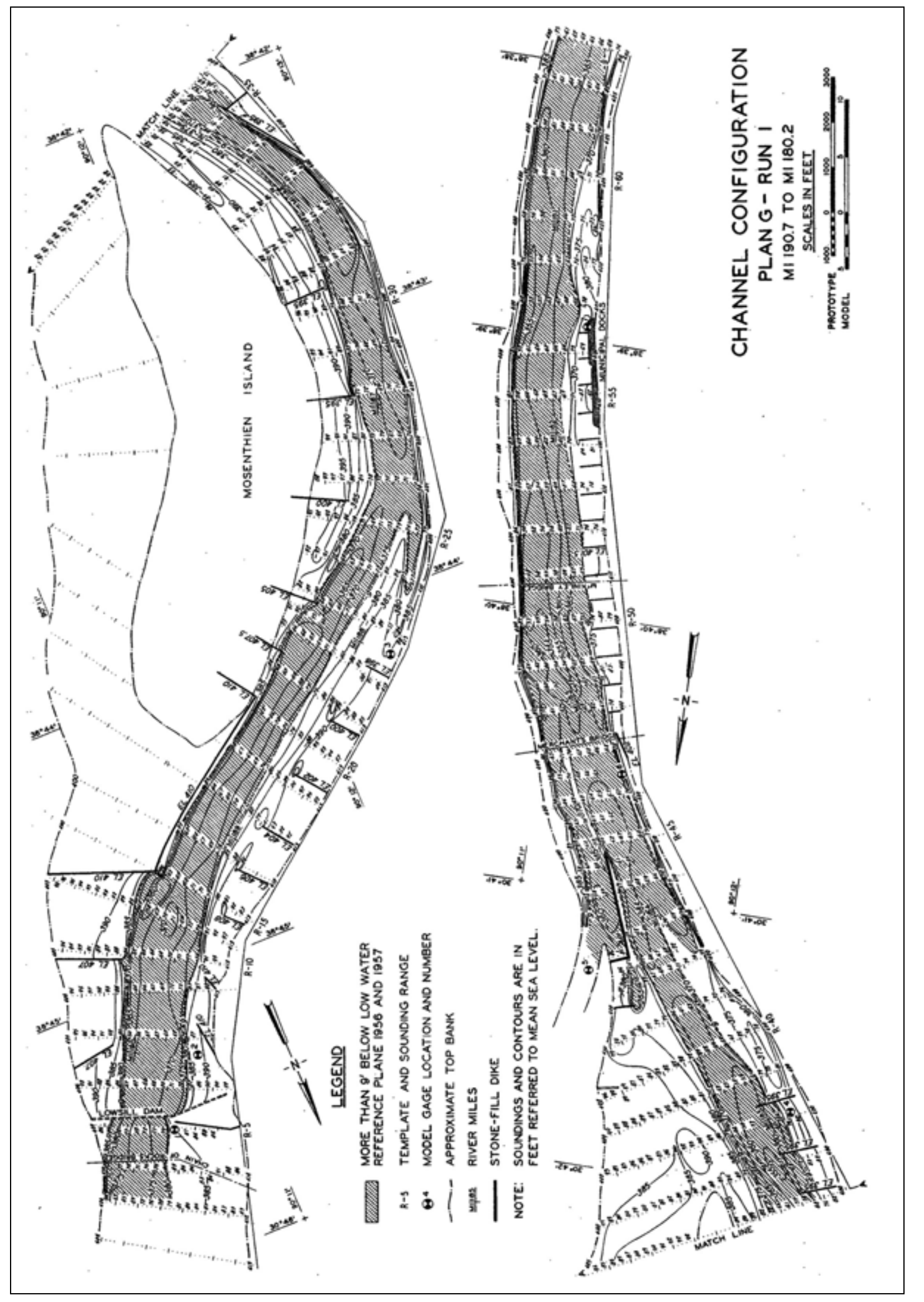

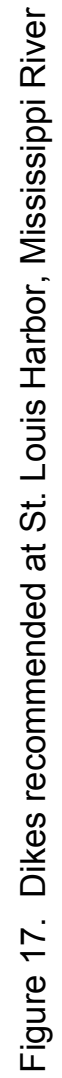




\section{Sediment Traps}

Catching sediment before it enters the sensitive area is an effective method for management of sediment deposition. Under favorable site and climate conditions this can be achieved by providing a sediment trap at a carefully selected location. Sediment traps do not catch all the sediment moving in the area. Therefore, channel maintenance dredging cannot be completely avoided, but the frequency and quantity of channel dredging can be significantly reduced. This increases the efficiency of harbor facilities and results in significant cost savings on maintenance dredging. The sediment trap must be emptied periodically through dredging to keep it functional. Although the volume to be dredged from the trap may sometimes offset any reduction in project shoaling, there can still be benefits:

- Navigation is not disrupted by shoaling in the project.

- Less frequent dredging usually reduces overall dredging costs.

- The trap can be intentionally located close to dredged material disposal areas, which results in reduced transportation time and cost.

Sediment traps are not very common because they can be effective only at highly selective locations and cannot be provided as a general solution to channel sedimentation problems. Physical or numerical model studies are very useful in designing sediment traps.

Large traps are dredged for sediment management of harbors and navigation channels. Such traps are designed with coastal jetties at tidal inlets or elsewhere inside estuaries and rivers. Parchure and Teeter (2002a) documented lessons learned from existing projects on shoaling in harbors and navigation channels, which also include dredged sediment traps.

\section{Sediment Trap Analysis}

When sediment-carrying currents flow normal or near normal to a navigation channel, the channel acts like a trap in collecting a part of the sediment crossing the channel and the remaining sediment is bypassed. Larson and Kraus (2001) give an analysis of the sediment-trapping phenomenon and a method to work out the trapping efficiency. The parameters that affect the efficiency of sediment traps are: depth of water inside and outside of the trap, type and particle size of 
the sediment, plan area of the trap, alignment of trap relative to the predominant current direction, magnitude and distribution of current velocity, and mode of transport of the sediments (bed load or suspended load). Sand traps are more efficient in catching bed load transport consisting of sand than in catching suspended sediment. Larger and deeper sediment traps may be required for trapping suspended sediment.

\section{Review of Select Case Studies}

Parchure and Teeter (2002b) conducted a review of potential methods adopted at several projects for reducing shoaling in harbors and navigation channels. The following case studies will illustrate the effective use of sediment traps at a few projects. It is interesting to note that in the case of Delaware City Channel project, studies indicated that sediment traps would have an adverse effect on shoaling (see Delaware City Channel study reported later in this chapter).

\section{Delaware River Channel}

A fixed-bed hydraulic model was used to qualitatively assess the relative merits of several shoaling-reduction proposals consisting of 17 plans for the Marcus Hook - Schuylkill River reach of the Delaware River (Bobb 1967). One of the conclusions of the study was that a combination of three sediment traps and a deepened portion of Marcus Hook anchorage would materially reduce navigation channel maintenance from the Philadelphia Navy Yard to Marcus Hook.

\section{Channel Islands Harbor, CA}

Sediment traps are used in conjunction with jetties to intercept and collect littoral sand, which might otherwise cause shoaling in a navigation channel. Hobson (1982) described the performance of a sediment trap at Channel Island Harbor, CA. The trap is positioned to interrupt the natural flow of sand transported along the coastline before it reaches the channel. This sand is periodically dredged and placed down coast where it is reintroduced to the natural transport system. A single updrift trap is used where longshore transport is dominantly

unidirectional, whereas traps on both sides of project may be employed to protect a channel where major transport reversals occur. The Channel Islands sediment trap has functioned well as designed by trapping the bulk of littoral drift sediment.

\section{Carolina Beach, NC}

The sediment trap in Carolina Beach Inlet has functioned fairly well but was located too close to the main flow through the inlet to be completely effective. Studies showed that relocation of the sediment trap seaward of and away from 
the main channel should greatly enhance its overall sand trapping ability. Jarrett (1988) made the following recommendations:

Sediment traps in tidal inlets should be located in areas removed from the concentrated tidal flows. For example, an ideal location for a sediment trap would be in the area of an existing interior shoal that is fed with littoral material moving off the inlet shoulders. In the case of Carolina Beach Inlet, much of the trap was located in the area of concentrated tidal flows and, as a result, the trap only filled to about 66 percent of its dredged capacity. The trap should also be dredged as deep as possible, but not deep enough to create a problem with sloughing of the adjacent shorelines into the trap.

\section{Savannah Harbor, GA}

Various plans to reduce heavy siltation in the harbor area of Front River were examined in a physical model (U.S. Army Engineer Waterways Experiment Station 1963). The recommended plan consisted of a 600-ft-wide, 40-ft-deep sediment trap (Figure 18) in the lower portion of Back River, and a tide gate structure in Back River upstream of the trap. The gates would be closed during ebb tide, forcing more flow down through Front River. This would flush sediments downstream in the navigation channel. The gates would be opened during flood tide, allowing normal flow up through Back River. This would attract sediments from the navigation channel into the Back River sediment trap. Relocation of the sediment deposition area not only reduced shoaling in the harbor area but also resulted in dredging operations closer to available disposal areas. Navigation channel shoaling was reduced by about 30 percent. The trap functioned very well for several years. The gates had to be removed later for environmental reasons.

Savannah Harbor investigations and physical model studies were also conducted earlier (U.S. Army Engineer Waterways Experiment Station 1961). Experiments were conducted to determine the most favorable conditions for a sediment basin and the effect of such a plan on the hydraulic regiment of the harbor. The effectiveness of the Back River sediment basin was greatly increased by the addition of a tide gate in Back River and a canal between Back and Front Rivers, which allowed the entire Back River tidal prism above the tide gate to empty through the canal and then through Front River. Several modifications of the basic plan were tested, and it was found that the most satisfactory plan was one which involved an increase in the size of the Back River tidal storage area above the tide gate and a 100 -ft-wide opening in the closure structure designed to be closed during dredging of the $40-\mathrm{ft}$ channel.

Use of the proposed Back River anchorage basin as an off-channel sediment trap would reduce shoaling in the navigation channel by about 20 percent, the greatest reduction being in the lower harbor. A tide gate located in Back River immediately above the sediment basin would improve the efficiency of the basin and reduce shoaling in the harbor by about 52 percent. The results of the investigation of shoaling and flow patterns in the vicinity of Middle River and adjacent to the sugar refinery and the entrance to the sediment basin indicated that shoaling in the vicinity of the sugar refinery would be eliminated and that flow 


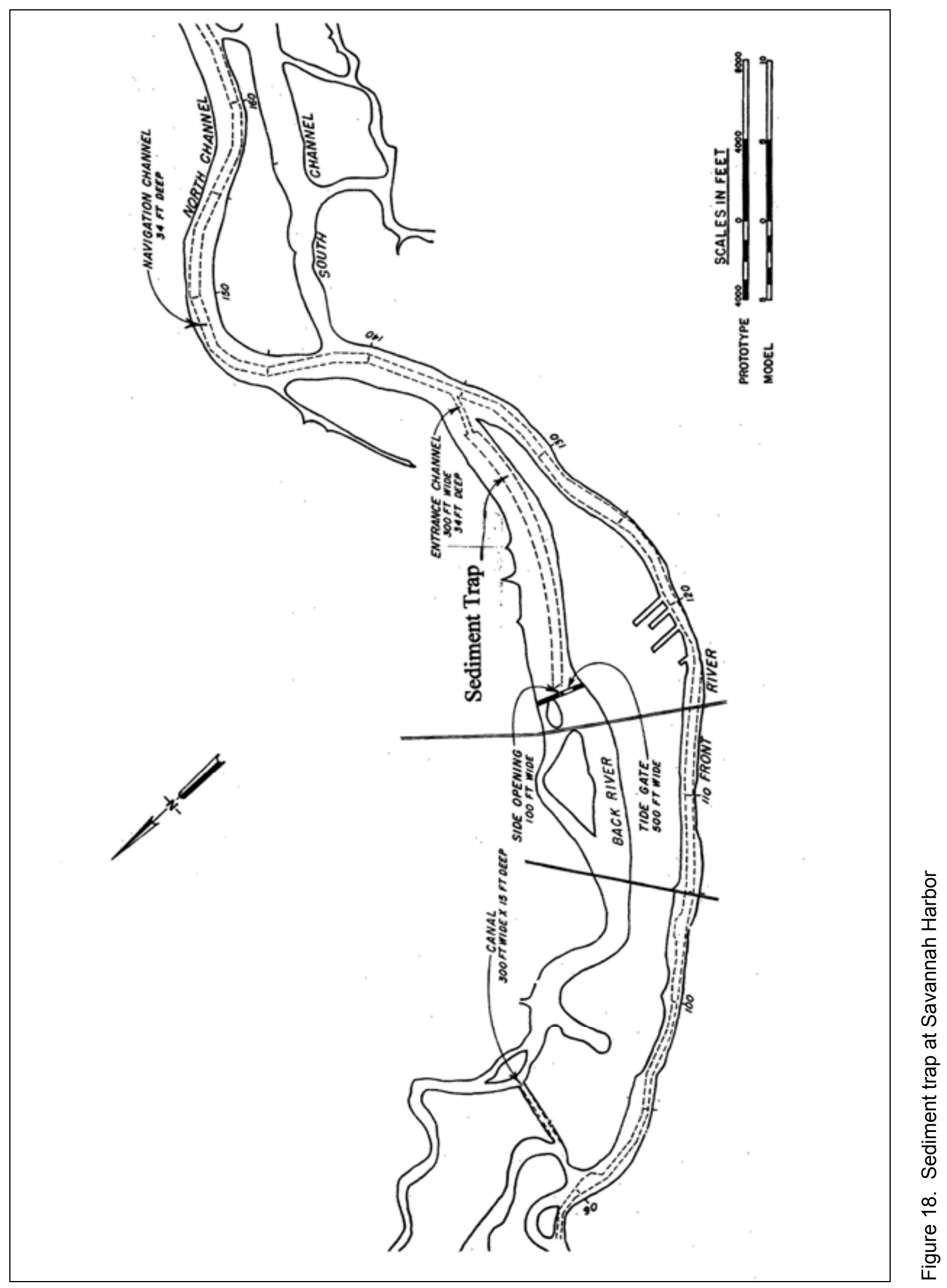


conditions at Middle River and the sediment basin would be no worse than those which already exist at the westerly junction of the north and south channels. Pollution tests indicated that only a slight increase in pollution would be experienced.

The purpose of the channel realignment at Elba Island was to eliminate a navigation hazard. Two schemes were considered for alternate alignments. Scheme 1 had a curved alignment, which proved to have a slight advantage over scheme 2, a straight alignment. In order to prevent shoaling in the realigned channel, constriction dikes were required at each end of the abandoned portion of the north channel, and model tests were conducted to determine the width of opening between the dikes that would most effectively trap and retain sediment and the effect of using the abandoned channel as a sediment trap. The tests indicated that a $100-\mathrm{ft}$-long opening would be optimum. The sediment trap was effective in trapping material, but since it would require maintenance, little benefit would be realized from the scheme except benefits to navigation.

The following conclusions were drawn from the model studies:

- The meeting of salt and fresh water in Savannah Harbor creates an environment in which density currents are superimposed upon the normal ebb and flood currents of the tide. This produces a net upstream flow at the bottom from the mouth of the river to the vicinity of the City Waterfront, and a net downstream flow at the surface throughout the harbor. The density effect is perhaps the greatest single factor in the shoaling process, given a supply source material for potential shoaling.

- Since the major source of supply for shoaling material is the fresh water flowing through the harbor to the sea, one method of attack was to remove the fresh water from the environment by diverting it to the sea by another route. This scheme had the advantage of removing both the source of sediment and the density currents.

- A second consideration in devising plans for reducing maintenance costs was that the existing problem had become acute not merely because of the necessity for maintenance dredging, but because the heaviest shoaling occurs at a point where dredged material placement areas had been exhausted. Any plan that would move the shoaling either upstream or downstream would be beneficial because it would make placement areas available to the dredging operations.

\section{Delaware City Channel}

The Tidewater Oil Company, Delaware Refinery, at Delaware City explored the possibility of reducing shoaling at their facility. Six plans were developed consisting of dikes and two locations of a sand trap (Bobb 1965). Results of a physical model study showed that all the plans tested had an adverse effect on total shoaling in the company channels. If the plans were implemented, total shoaling was expected to increase by amounts varying between about 50,000 and $475,000 \mathrm{cu}$ yd/year, depending upon the plan. 


\section{Rollover Pass, TX}

Rollover Pass is a narrow, man-made channel that connects the Gulf of Mexico and Rollover Bay. The Gulf Intracoastal Water Way (GIWW) crosses Rollover Bay on the north side of Rollover Pass. The U.S. Army Engineer District, Galveston, maintains a navigation channel, $40 \mathrm{~m}$ wide and $3.6 \mathrm{~m}$ deep within the GIWW for commercial barge traffic. Over the past several years, considerable siltation has been taking place within the GIWW in the vicinity of the Rollover Pass area, and periodic dredging is required for maintaining navigable depths. The U.S. Army Engineer Research and Development Center (ERDC), Vicksburg, MS, examined ways to reduce siltation of the channel. The objective of the study was to construct a working numerical model of the Rollover Pass area and use the model for design of a sediment trap, which would be feasible and effective in reducing the frequency of dredging in the GIWW. Parchure et al. (2000) described the design of a sediment trap at this location. The hydrodynamic model code RMA2, available through ERDC, was used to calculate the hydrodynamics of the system. This two-dimensional model was verified using field data. Velocity patterns under selected tidal conditions were generated.

Field data collected from the site included bed samples, water samples, and past dredging records. Median diameters of bed samples are shown in Figure 19. The reach of channel directly in the path of flood currents through the inlet consisted of sand, whereas on both sides of this reach the bed material consisted of fine sediments. The average composition of the bed samples consisted of 30-percent sand, 50-percent silt, and 20-percent clay. Coarse sediment appeared to be traveling from the sea all the way to the GIWW, whereas East Bay was the source of finer sediment. Analysis of dredging records showed (Figure 20) that a length of GIWW between sections 2136 and 2166 had a much higher rate of sediment deposition. Computation and analysis of bed shear stress patterns were used along with the velocity data to estimate where and by how much sediment deposition was expected to occur. Several alternative sediment trap layouts in terms of location, shape, size, and depth were used for evaluation. The recommended layout is shown in Figure 21.

The recommended sediment trap layout has a length of $915 \mathrm{~m}$ and a width of $120 \mathrm{~m}$ and is separated from the GIWW by a distance of $60 \mathrm{~m}$. The $120-\mathrm{m}$ width would be needed not only for obtaining better trapping efficiency but also for providing adequate room for maneuvering a dredge inside the trap. Recommended design depth in the trap is $2.75 \mathrm{~m}$, which is expected to be adequate for safe dredging operations. If it is found to be necessary and advantageous, the width and depth of the trap may be varied in the future.

It is recommended that the new sediment trap be dredged over a smaller area. Its effectiveness should be monitored over the 2 years following construction. Expansion of the trap over larger areas in the next two phases should be done later, if experience shows that the first phase is having the desired effect. The proposed trap is expected to catch the excessive sediment accumulating between sections 2136 and 2166 and prevent formation of a local hump, which at present necessitates more frequent dredging. The sediment trap is expected to reduce the 


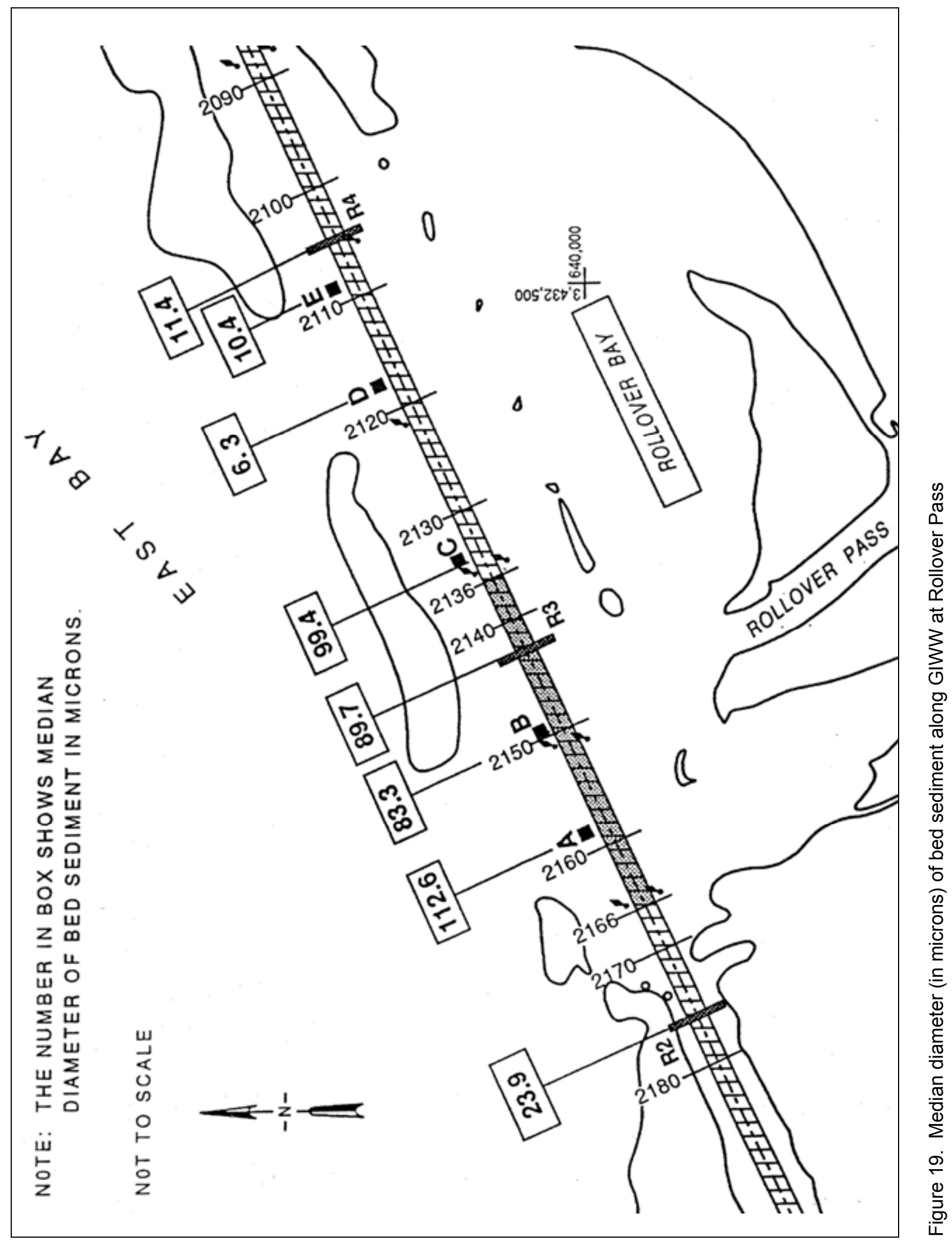




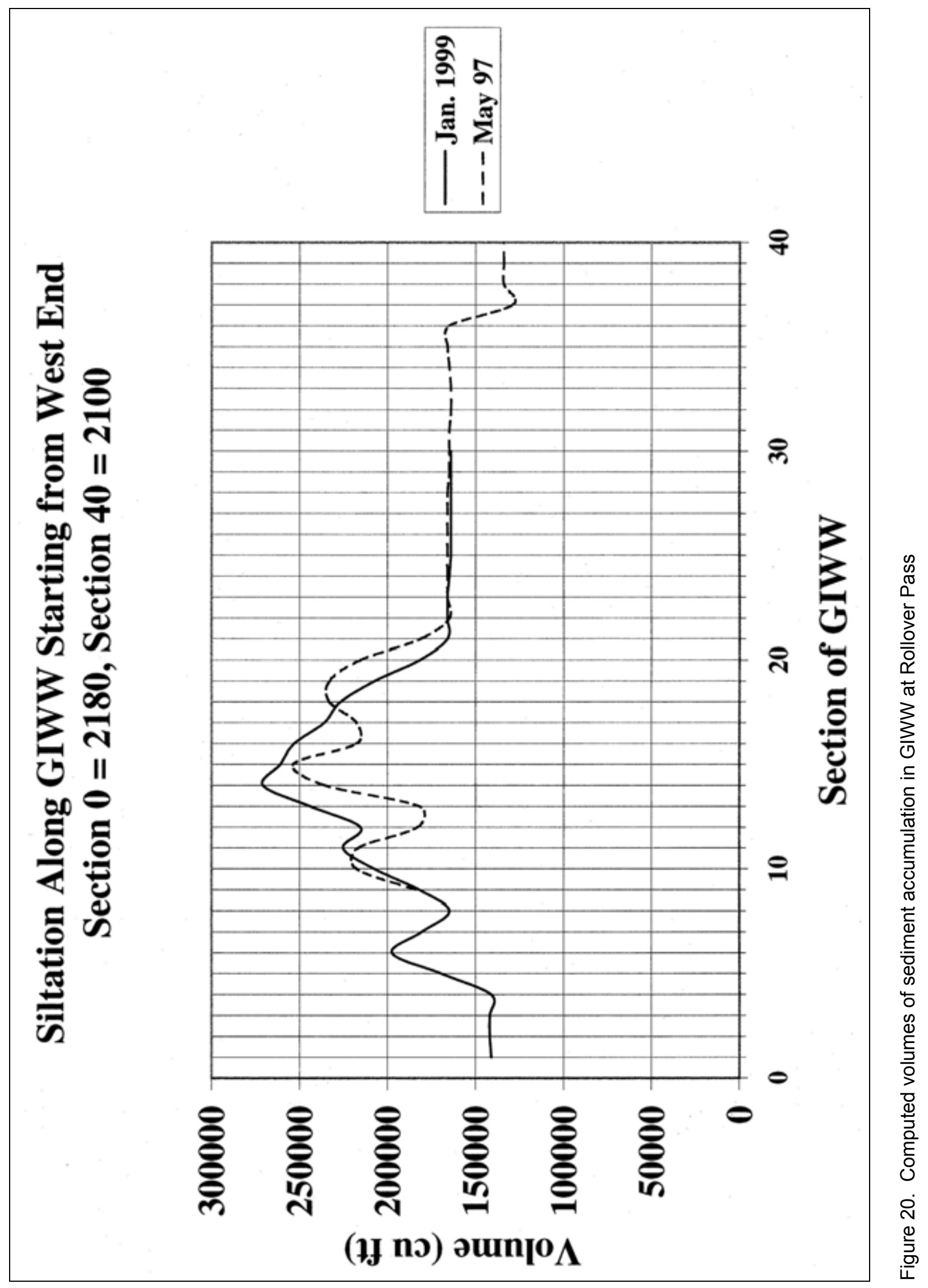




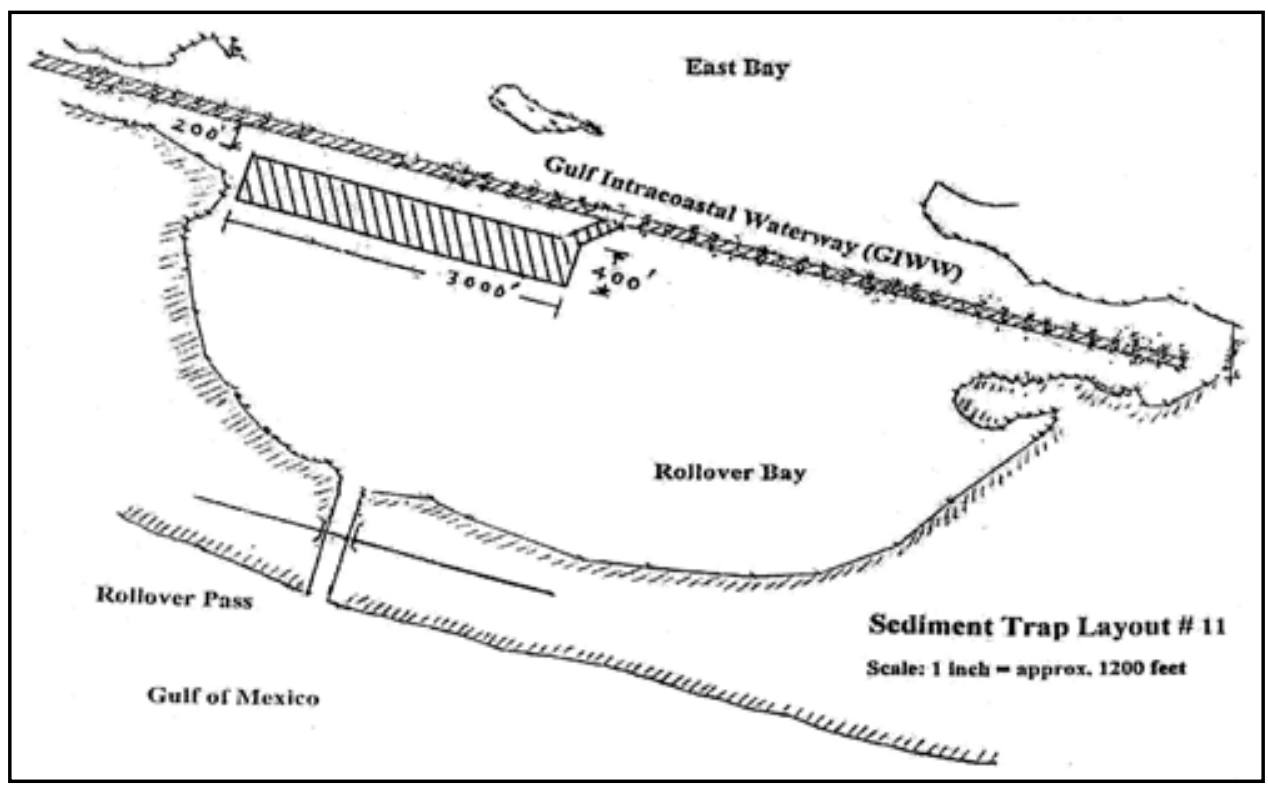

Figure 21. Recommended sediment trap layout at Rollover Pass

frequency between consecutive dredging operations and the average annual cost of dredging.

The recommended trap configuration has the following features. It is not connected to the GIWW over its entire length. It does not include construction of any structures. It provides one connection with the GIWW for a dredge to enter. The trap does not permit a "flow-through" hydraulic condition. Phasing of dredging work for future expansion is easy and feasible. The sediment removed for making the trap should be deposited on the eroding beach, provided it is suitable for beach nourishment.

Environmental impacts of the sediment trap were not examined in the study. The Galveston District has accepted the recommendation and is proceeding with plans for construction. Field data on its functioning will be available after the trap is constructed.

\section{Visakhapatnam Port, India}

The ancient Visakhapatnam Port, located on the east coast of India, is an inland port connected to the sea by a long navigation channel. Though well protected from waves by a natural geographical configuration, presence of bedrock at shallow depths below sea level precluded economic expansion of the port for modern, deep-draft vessels up to 150,000 DWT having drafts up to $15 \mathrm{~m}$. Therefore, a new outer harbor enclosed by long breakwaters was constructed for wave protection. While littoral drift occurs in both directions at this site, the predominant direction is northward, and construction of a shore-connected breakwater would result in large sediment accumulation on the south side, resulting in sand bypassing into the navigation channel after a few years. It was 
proposed to provide a gap between the shoreline and south breakwater and locate a sand trap within the gap (Figure 22) for trapping littoral drift.

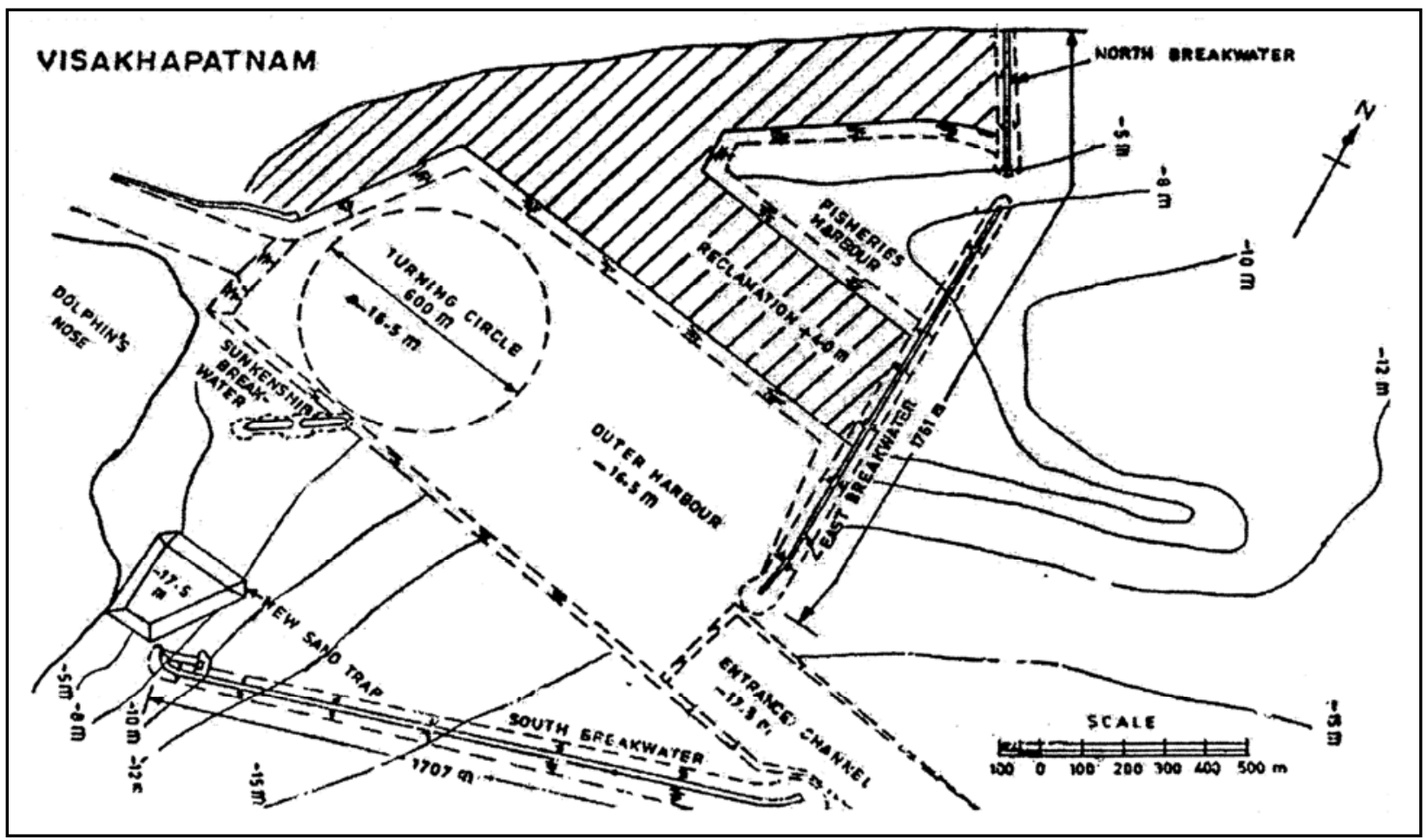

Figure 22. Sediment trap at Visakhapatnam Harbor, India

Parchure (1978) describes the studies conducted at the Central Water and Power Research Station, Pune, India, for a new sand trap designed for the Visakhapatnam Outer Harbor. Quantitative estimation of littoral drift was a major component of this study. Wind data for the past several years were obtained from the India Meteorological Department. These data were analyzed and wind rose diagrams plotted. Wave rose diagrams were constructed by employing hindcasting techniques, which use wind and fetch data as input and calculate wave heights and periods. Wave data reported for ships from offshore locations were used for validation. Wave-induced sediment transport was computed and sitespecific correlations established between the wave energy and littoral drift rates. It was estimated that for an average annual wave climate, the net northward littoral drift would be 700,000 cu m.

Movable bed model studies were conducted on a wave-current physical model having horizontal and vertical scales of 1:240 and 1:80, respectively. Crushed walnut shells having a specific gravity of 1.36 and a median diameter of $0.6 \mathrm{~mm}$ were used as bed material. Field data on shoreline changes and quantities of sediment collected in the existing sand trap were used for model validation. After testing several layouts for a sand trap, the final layout shown in Figure 22 was recommended. It had a volumetric capacity of $600,000 \mathrm{cu} \mathrm{m}$ and a bed level of $17.5 \mathrm{~m}$ below sea level. It was estimated that the south breakwater would arrest 21 percent of littoral drift, while the new sand trap would catch 66 percent 
and the remaining 13 percent would bypass the system. The new sand trap has been functioning successfully since its construction in the late 1970's.

\section{Colorado River, TX}

Layout of the Colorado River mouth is shown in Figure 23. Two jetties have been constructed at the mouth for stabilizing its position. The along-shore littoral drift causes sediment to accumulate on the updrift side. The eastern jetty is provided with a weir section near the shore for spilling sand in a dredged sediment trap. This sediment trap has been in operation over the past several years. The trap is dredged periodically in anticipation of shoaling from littoral transport. Loss of depth on the order of several feet is experienced in a single storm representing heavy siltation in the trap, thus keeping the navigation channel in operation.

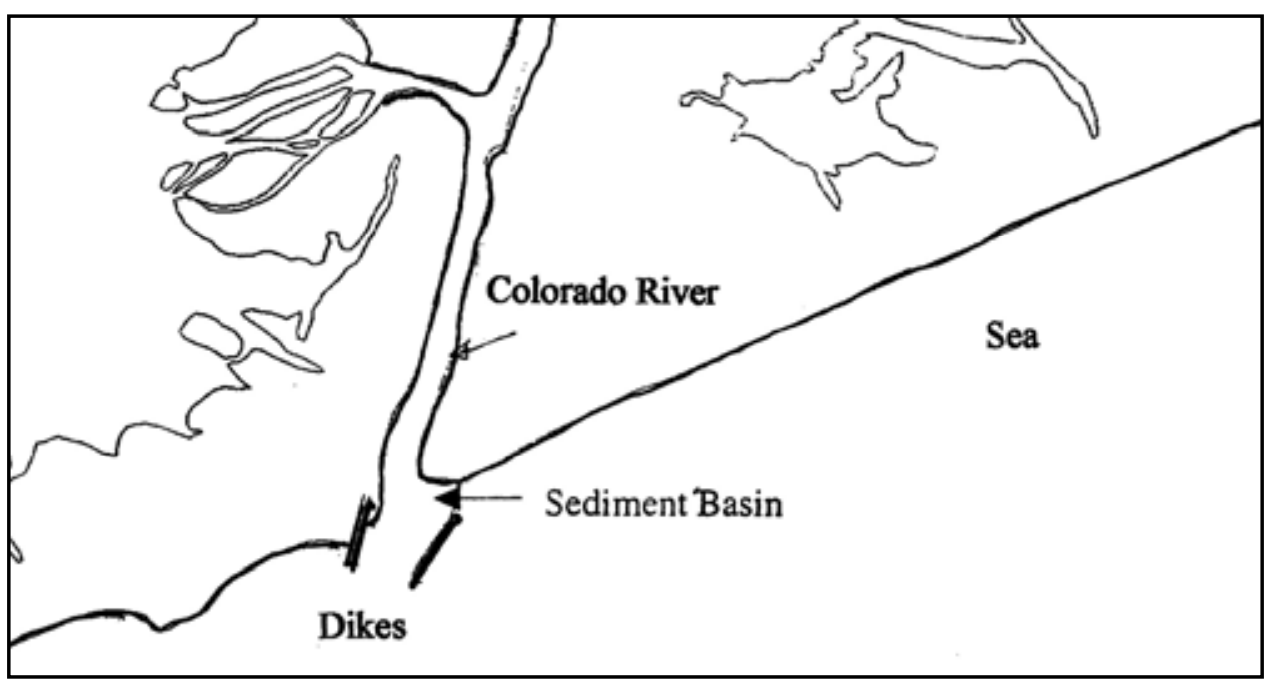

Figure 23. Sediment basin at Colorado River mouth, TX

\section{Murrell's Inlet, SC}

Rosati and Kraus (1999) reported on the design and functioning of a deposition basin at Murrell's Inlet, SC. A dual jetty system was constructed in 1977 with a 400-m-long weir section close to the shore on the north jetty. The crest elevation of the weir was $0.4 \mathrm{~m}$ above mean low water ( $\mathrm{mlw}$ ), and a deposition basin was dredged at $6 \mathrm{~m}$ below mlw on the lee side of southerly littoral drift. The navigation channel bed elevation was at $3 \mathrm{~m}$ below mlw. Results of a 9-year monitoring program indicated that the sediment tended to be transported over and through the weir jetty; however, some of the sediment then bypassed the deposition basin and deposited in the navigation channel. It is likely that a sediment deflector wall (which was recommended but not constructed) would have retained sediment within the deposition basin. 


\section{Coastal Structures}

Many of the world's harbors have used existing tidal inlets to develop a sheltered harbor on the landside by dredging a navigation channel connecting the harbor to the sea through the inlet. Many coastal harbors have been constructed seaward of an existing shoreline by constructing breakwaters to provide protection to vessels against waves. Jetties have also been constructed at tidal inlets to prevent coastal sedimentary processes from closing the harbor and also to prevent sediment migration along the shore. Two types of shoaling problems are experienced at these projects. The first problem is sediment from offshore sources entering the navigation channel from the ocean due to tidal influx and depositing in the harbor areas. The prevailing alongshore littoral drift causes the second shoaling problem. While the breakwaters prevent sediment entering the navigation channel, a large volume of sediment accumulates on the updrift side of the man-made obstruction. This accumulation interferes with the supply of sediment on the other side of inlet resulting in severe erosion on the downdrift side. Sediment bypassing measures are needed to overcome this problem. Examples of existing projects with coastal sediment problems are presented in this chapter.

\section{Jetties}

Numerical model studies have been reported by McAnally (1983) on the examination of the effect of the south jetty at the Columbia River mouth along with jetty modifications to reduce channel shoaling. The seaward portion of the jetty was degraded to elevations below low tide levels. Rehabilitation of the jetty to its original abovewater crest elevation was previously authorized. The model study indicated that, in its present condition, navigation channel shoaling is less than with the rehabilitated condition. The degraded seaward portion of the jetty seems to act as a weir preventing some bottom sediments from entering the entrance channel during flood currents. The submerged portion of the jetty is sufficient to confine ebb currents and flush sediments out into the ocean. Thus, in this specific case, the current length of the jetty was found to be the optimum; however, the efforts have demonstrated the utility of such a study in optimizing the layout of critical structures related to dredging quantities. Use of the numerical model study avoided expensive and possibly potentially adverse/irreversible field construction work. 


\section{Breakwaters}

Cattaraugus Creek, located on the south shore of Lake Erie, NY, is approximately 70 miles long and flows generally westward, entering the lake about 24 miles southwest of Buffalo Harbor, NY. Flooding occurs almost every year along the lower reaches of Cattaraugus Creek when melting snow and spring rains swell the creek. This flooding is partially due to the limited capacity of the existing creek channel, but the major contributing factor is the presence of a restrictive sand and gravel bar at the creek mouth. Formed mainly by littoral drift due to wave action, at times this bar virtually closes the outlet and provides a natural barrier encouraging the formation of ice jams, which cause significantly higher stages and damages than those caused by discharge alone.

Navigation difficulties are also experienced at the mouth of the creek due to the shallow depths and the constant shifting of the bar across the entrance. Improvements at the mouth and lower reaches of the creek were needed to rectify the shoaling problems. Studies were conducted (Bottin and Chatham 1975) on a 1:75 undistorted wave model. Out of the nine improvement plans tested involving a navigation opening and entrance channel oriented toward the northeast, the plans consisting of constructing rubble mound breakwaters and reducing the navigation opening between the breakwaters to $300 \mathrm{ft}$ provided the best protection with respect to shoaling.

\section{Port Orford, OR}

A breakwater constructed at Port Orford in 1935 was extended by $550 \mathrm{ft}$ in 1961. This extension altered the current pattern in the harbor adversely by forming an eddy, which induced sediment deposition. Soon after the breakwater extension, the harbor area adjacent to the pier started shoaling. Chatham (1981), reporting on hydraulic wave model studies conducted to rectify the situation, concluded that removing segments of breakwater, or breakwater realignment or lengthening of the existing breakwater along the same alignment, would not be beneficial. Instead, an extension of the Fort Point breakwater by $600 \mathrm{ft}$ at an angle of south 45 deg west would prevent shoaling by wave-induced currents from any prevailing direction. This case shows that well studied structural modifications can be beneficial as remedial measures. Usefulness of hydraulic model investigations in discarding unfavorable options and selecting the correct option is also demonstrated by this case.

\section{Ocean City Inlet, MD}

Permeable jetties and jetties with crest elevations that are low relative to the adjacent beach can contribute to erosion of the adjacent beach and shoaling of the inlet channel. Rosati and Kraus (1999) reported on the functioning of Ocean City Inlet, $\mathrm{MD}$, as an example where modifications were made to the south jetty because water and sand were flowing over and through the jetty. A new south jetty was constructed $10 \mathrm{~m}$ south of the existing jetty with a crest elevation of $3.3 \mathrm{~m} \mathrm{msl}$ instead of the earlier $1.2 \mathrm{~m} \mathrm{msl}$; an impermeable core was provided, 
and three headland breakwaters were constructed. Results of a monitoring program indicated that the rehabilitation effort successfully met its goal in eliminating the shoaling problem.

\section{Multiple Methods}

Weishar and Aubrey (1988) concluded that the sediment transported from the ocean by the combination of wave refraction, reflection, and propagation processes is primarily responsible for shoaling at Green Harbor, MA.

The following recommendations were made for reducing shoaling:

- Reduce the volume of sand on the lee side of west jetty.

- Raise the crest elevation of the east jetty to minimize wave overtopping during storms.

- Eliminate or reduce the length differential between the east and west jetties, thereby reducing wave reflection.

- Provide bank protection to reduce erosion.

- Implement a beach grass plantation program augmented with sand fencing to minimize aeolian sand transport. 


\section{Other Structures and Multiple Structures}

Navigation channel shoaling is a problem as old as navigation itself. Effective solutions to these problems have evolved over centuries of experience. These solutions may be considered as standard measures although site-specific studies must be conducted to evaluate their applicability. Solutions consist of breakwaters for coastal projects, dikes for river projects, and sediment traps. None of these solutions may be effective at some project sites due to site locations and different site conditions. Innovative measures and combinations of several methods have been successful through research at many projects. These projects and measures are described in this chapter.

\section{Current Deflector Wall at Hamburg, Germany}

A structure called a "current deflector wall" (CDW) has been successfully used at Hamburg Port, Germany (Figure 24) in reducing channel shoaling. Eddy currents often cause shoaling, and dredging the shoal is not always cost-effective. The CDW, developed in Germany, is an innovative low training structure used to eliminate eddy currents. It is a fixed, vertical-walled structure with a curved partition that extends through the full depth of water. A rounded, vertical-walled addition to the existing upstream entrance corner is usually required to complement the CDW. The current deflector structure modifies flow patterns in such a way as to break down or prevent formation of eddies. This method has been successfully used in 1990 at the Kohlfleet Harbor, Port of Hamburg, Germany. The CDW has eliminated eddy formation, improved navigation, and resulted in about a 40 -percent reduction in shoaling.

Alexander (1993) performed an engineering evaluation of the CDW as a device for navigation channel maintenance. He cautioned that while considering $\mathrm{CDW}$ as an option, it is important to distinguish eddy-generated problems that make such a structural alternative feasible.

A new name has been given to this type of measure for shoaling reduction, the "entrance flow optimization system," which includes current deflecting walls and other passive structures. Additional information on this method may be obtained from International Dredging Review (1994). 


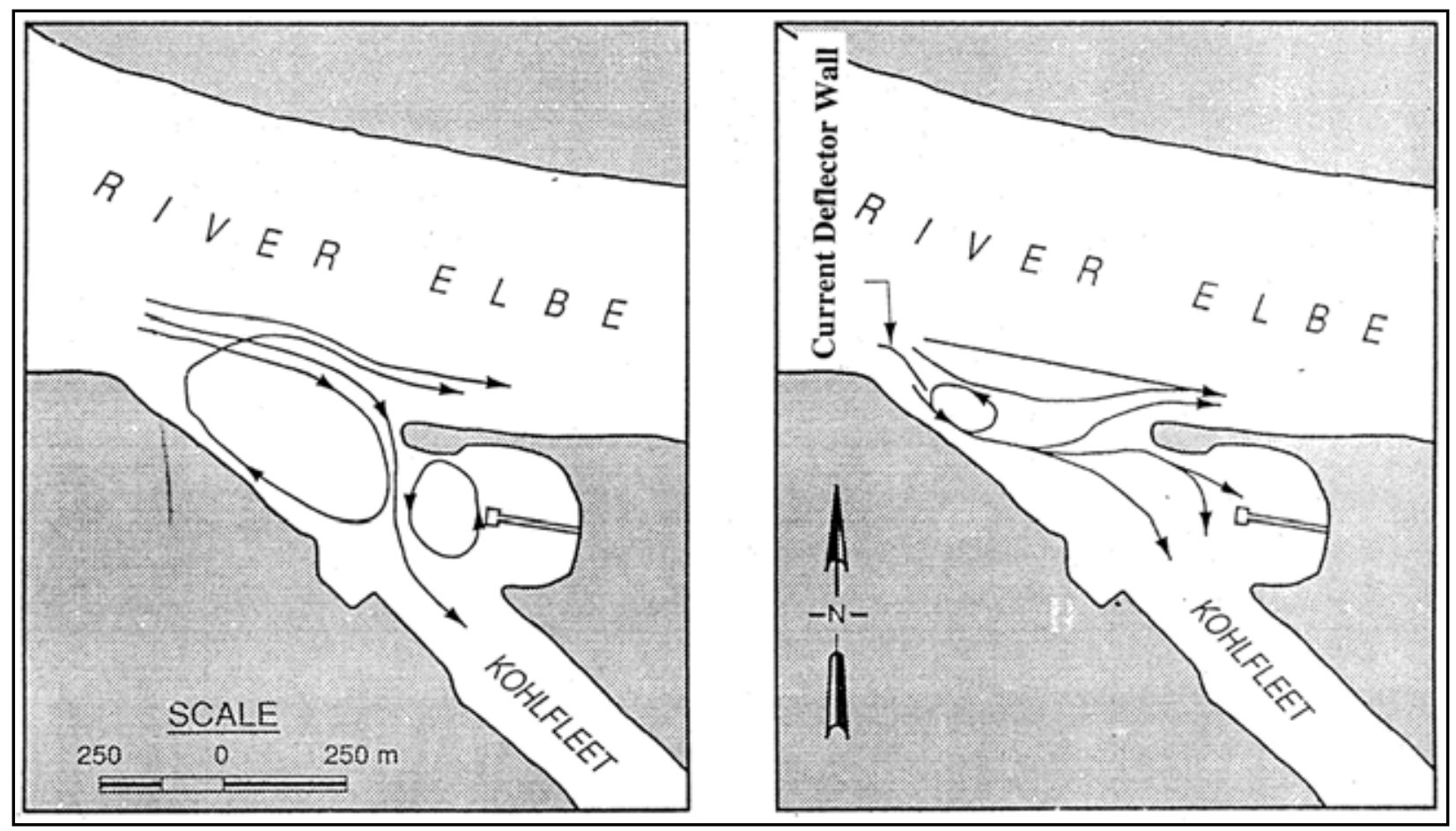

Figure 24. CDW at Hamburg Harbor, Germany

\section{Current Deflector Wall at Antwerp}

CDW is being considered at the new Deurganckdok Harbor at Antwerp. Although CDW has reduced siltation at Hamburg Harbor, Germany, it was earlier thought that it may not be applicable at Antwerp because of prevailing salinity gradients, which are absent at the Hamburg Harbor. The effect of a CDW, which is an obstruction to deviate the currents, is not well known when density-induced currents occur. Hofland et al. (2001) reported in a subsequent study that a CDW could be effective under density-induced currents; however, site-specific studies are essential. Also, another large tidal basin located downstream of Deurganckdok on the same bank of Scheldt is under consideration. Hence the study includes an additional parameter, namely, the far-field effects of CDW.

\section{Multiple Structures at Mare Island Naval Shipyard}

The Mare Island Naval Shipyard (MINS) was the first U.S. naval station established on the Pacific Coast. It is located in Solano County, CA, approximately 25 miles northeast of San Francisco. The Napa River (Mare Island Strait) separates the peninsula shipyard from the City of Vallejo. MINS was identified for closure during the Base Closure and Realignment process of 1993. Naval operations ceased and the facility was decommissioned on April 1, 1996. 
The following four devices at MINS, reported by Bailard et al. (1986), have been validated through field tests and have shown great potential in reducing the Navy's maintenance dredging burden.

Device 1: Spatial scour jet array. A scour jet array system is effective in reducing unwanted sediments. The system consists of a series of horizontal, nearbottom water jets, which are briefly activated during each ebb tidal cycle. The bed shear stress imposed by the jet discharge resuspends recently deposited sediment, creating a fan-shaped scour pattern in front of each jet. Once suspended, the sediment is carried away from berthing area by tidal currents during ebb.

Device 2: Vortex foil array. A vortex foil array device can be used to reduce sedimentation at berthing and approach areas exposed to moderate currents. These arrays consist of a series of underwater foils, similar in cross section to airplane wings, moored about $3 \mathrm{ft}$ above the bottom by a short tether wire connected to a swivel and screw anchor. Each delta-shaped foil is buoyant, with its lifting surface oriented either upward (a downwash foil) or downward (an upwash foil). Tidal currents flowing past the foil cause horseshoe-shaped vortices to be shed from the foil's trailing edge. The vortices are directed downstream by the current, enhancing the bottom shear stress and resuspending newly deposited sediments. In the downwash mode, the full energy of the vortices is directed at the bottom, resuspending loosely consolidated sediment. In the upwash mode, the sediment is directed into the water column and carried out of the berthing area by the tide. Normally, combinations of downwash and upwash foils are used.

Device 3: Barrier curtain. Barrier curtains are effective in reducing sedimentation in semienclosed berthing areas with limited flushing. They work on the exclusion principle. Field studies have shown that, under conditions of deposition, 90 percent of the sediment is carried in the lower 10 percent of the water column. As a result, a partial height curtain can be used to exclude the sediment-laden bottom water from a berthing area, while allowing normal tidal exchange to occur at the surface. These curtains are pneumatically controlled for raising and lowering to accommodate navigation.

Device 4: Venting canal concept. This device developed by the Scripps Institute of Oceanography has been evaluated by the Navy for reducing sedimentation in the turning basin at the Naval Station Mayport, Florida. The concept involves constructing a shallow canal connecting the basin with the adjacent St. John's River. The canal would function by preferentially filling the turning basin with relatively sediment-free water entering the existing entrance channel.

\section{Sediment Barrier at La Quinta, TX}

Parchure et al. (2002) reported on a study conducted for the La Quinta Navigation Channel project, TX. The channel layout is shown in Figure 25. Two modifications to the existing channel were examined: one was extending the channel for expansion of navigation facilities, and the other was providing a sediment barrier on the south side of extended channel (Figure 26). A desktop 


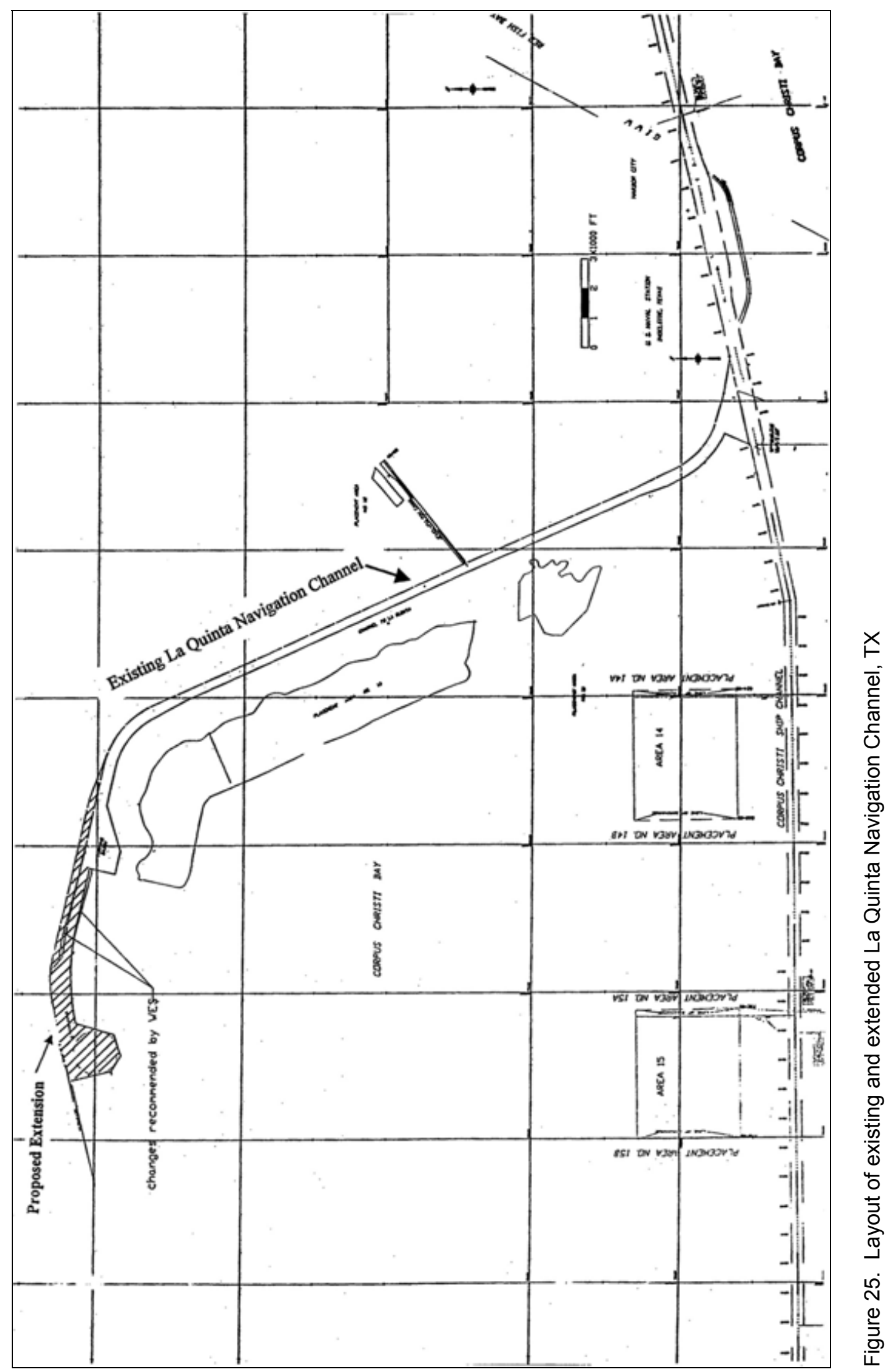




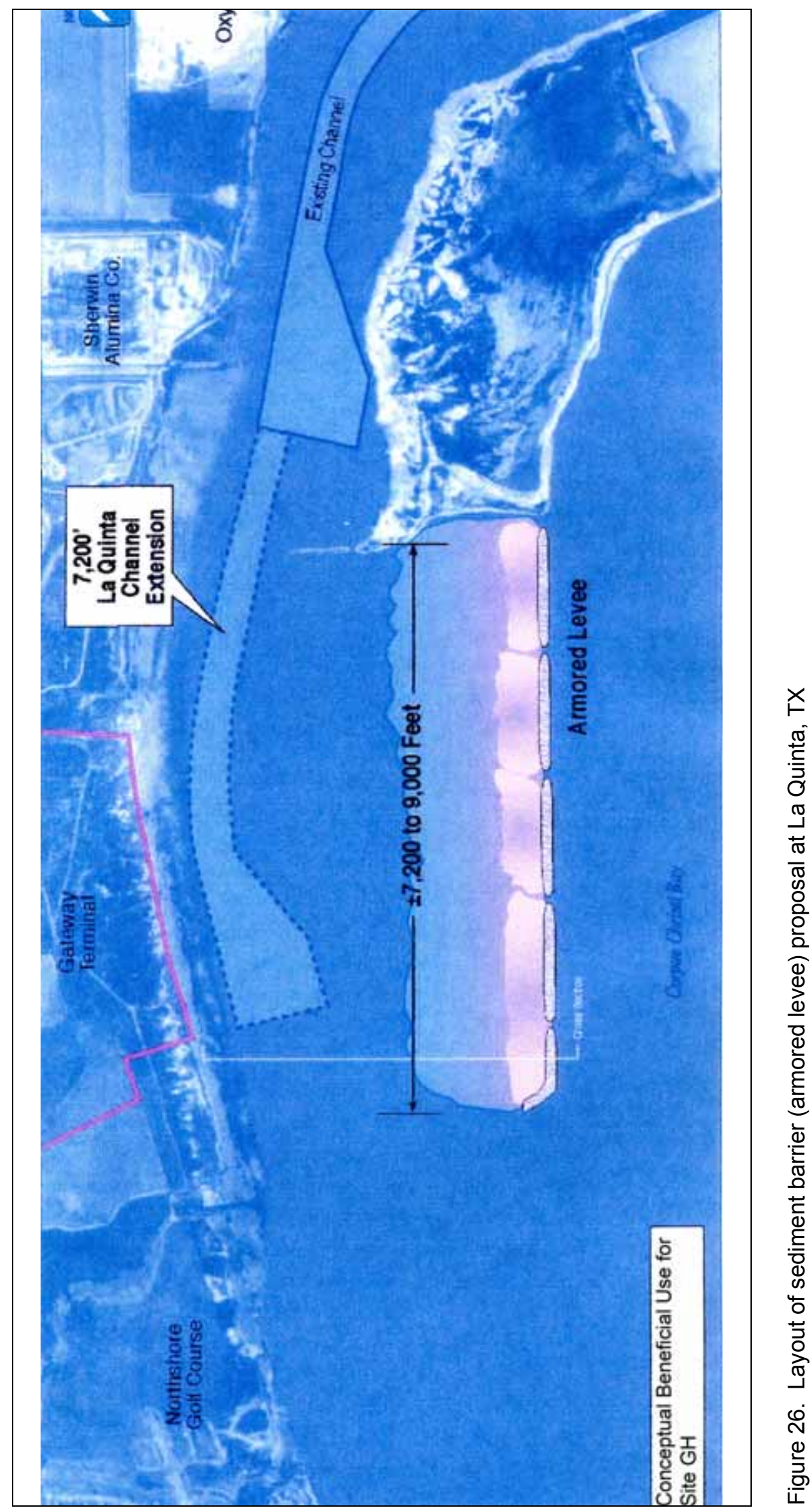


study was conducted at ERDC for estimating the annual shoaling rate in the extended channel. The effect of the barrier on channel siltation was also examined during the study. It was concluded that the barrier would be effective in arresting bed load transport from the south and thus aid in reducing maintenance dredging quantity in the extended channel.

\section{Flow Diversion at Charleston Harbor, SC}

The Charleston Harbor, SC, was deepened from 30 to $35 \mathrm{ft}$ in the 1940's. Also, a large amount of water from the Santee River was diverted to the Cooper River in 1942 as part of a power generation project. This diversion increased the average annual freshwater discharge into Charleston Harbor from $800 \mathrm{cfs}$ to between 2,000 and 28,000 cfs, depending on the electrical demand. Shoaling in Charleston Harbor, located on the Cooper River, increased from 110,000 cu $\mathrm{yd} /$ year for the preproject condition to 10 million cu yd/year after the project. The Committee on Tidal Hydraulics (1966) concluded beyond reasonable doubt that the increased freshwater flow transformed the earlier, well mixed estuary into a partly mixed estuary, increasing the predominance of flood currents at the bottom. This transformation prevented the load of near-bottom suspended sediment in the river from discharging into the sea, and instead depositing within the harbor area.

In order to restore the preproject conditions of low maintenance dredging, it was necessary to re-divert water from the Cooper River back to the Santee River. At the same time it was necessary to maintain adequate flow in the Cooper River to flush pollutants and to meet health, aesthetic, and recreational requirements. Studies indicated that a flow of 3,000 cfs would be sufficient to revert Charleston Harbor to a well mixed type of estuary. It was estimated that the rate of maintenance dredging following rediversion would probably be 40 to 75 percent less than the average during the 16-year period 1966-1982 (Patterson 1983).

Teeter (1989) analyzed field data on various parameters before and after rediversion. He concluded that the harbor conditions were optimum for a river discharge between 3,000 and 4,500 cfs. This flow range was recommended as the weekly average flow in Cooper River from Pinopolis Dam. The average annual gross dredging for the Charleston Harbor for the period 1965 through 1984 was 6.19 million cu yd. The reduction in dredging after rediversion was estimated to be between 70 and 74 percent, depending on the variation in the amount of freshwater flow from 4,500 to 3,000 cfs, respectively.

\section{Channel Closure on Ohio River}

Investigation was conducted (Franco and Pokrefke 1983) at WES for the development of plans for the Smithland Locks and Dam located on the Ohio River at river mile 918.5. The study indicated that closure of the channel between Cumberland Island and the left bank of the Ohio River near the head of the island would tend to cause shoaling in the entrance to the channel between Cumberland and Towhead Islands. Developments in the channel downstream of the structure 
would be affected by the elevation and shape of bedrock downstream of the gated spillway. Deep scour would occur downstream of the gates near the fixed weir with flow from the scour moving mostly toward the right bank some distance downstream with deposition along the right side of Cumberland Island. Dikes would be required along the right bank to prevent the channel from meandering between the right bank of Ohio River and Cumberland Island.

\section{Channel Closure at Delaware River Channel}

The Marcus Hook - Schuylkill River reach of the Delaware River had sediment shoaling problems. A fixed-bed hydraulic model (Bobb 1967) was used to qualitatively assess the relative merits of several proposals consisting of 17 plans. The following conclusions were drawn based on the model studies:

- A significant reduction in back-channel shoaling can be achieved by complete closure of the Tinicum Island back-channel.

- A 250-ft-wide small boat channel through Tinicum Island will decrease the reduction in shoaling but will improve circulation.

- A combination of three sediment traps and a deepened portion of Marcus Hook anchorage would materially reduce navigation channel maintenance from the Philadelphia Navy Yard to Marcus Hook.

Sediment traps for the Delaware River Channel have been described under Chapter 4.

\section{Channel Closure at San Diego River}

Figure 27 shows a layout of providing two separate channels at the San Diego River mouth. Local geographical configuration of the site permitted providing a sediment barrier and a separate channel in order to isolate the Quivira Basin from the influence of flow and sediment from the San Diego River. Construction of three jetties at the river mouth along with an upstream sediment barrier provides an effective way of reducing harbor shoaling.

\section{Barrier at Dillingham Harbor, AK}

Harbor shoaling is a significant problem when coastal waters are laden with suspended solids and the tidal range is high, such as in Alaska. Under these circumstances "half-tide" harbors are often constructed as enclosed basins adjacent to, rather than within, navigable estuaries for use of small crafts. The unique feature of a half-tide harbor is a "sill" placed in the navigation channel at an elevation higher than the bottom of the harbor basin. When the tidal level is low, the sill retains water in the harbor for vessel flotation. 


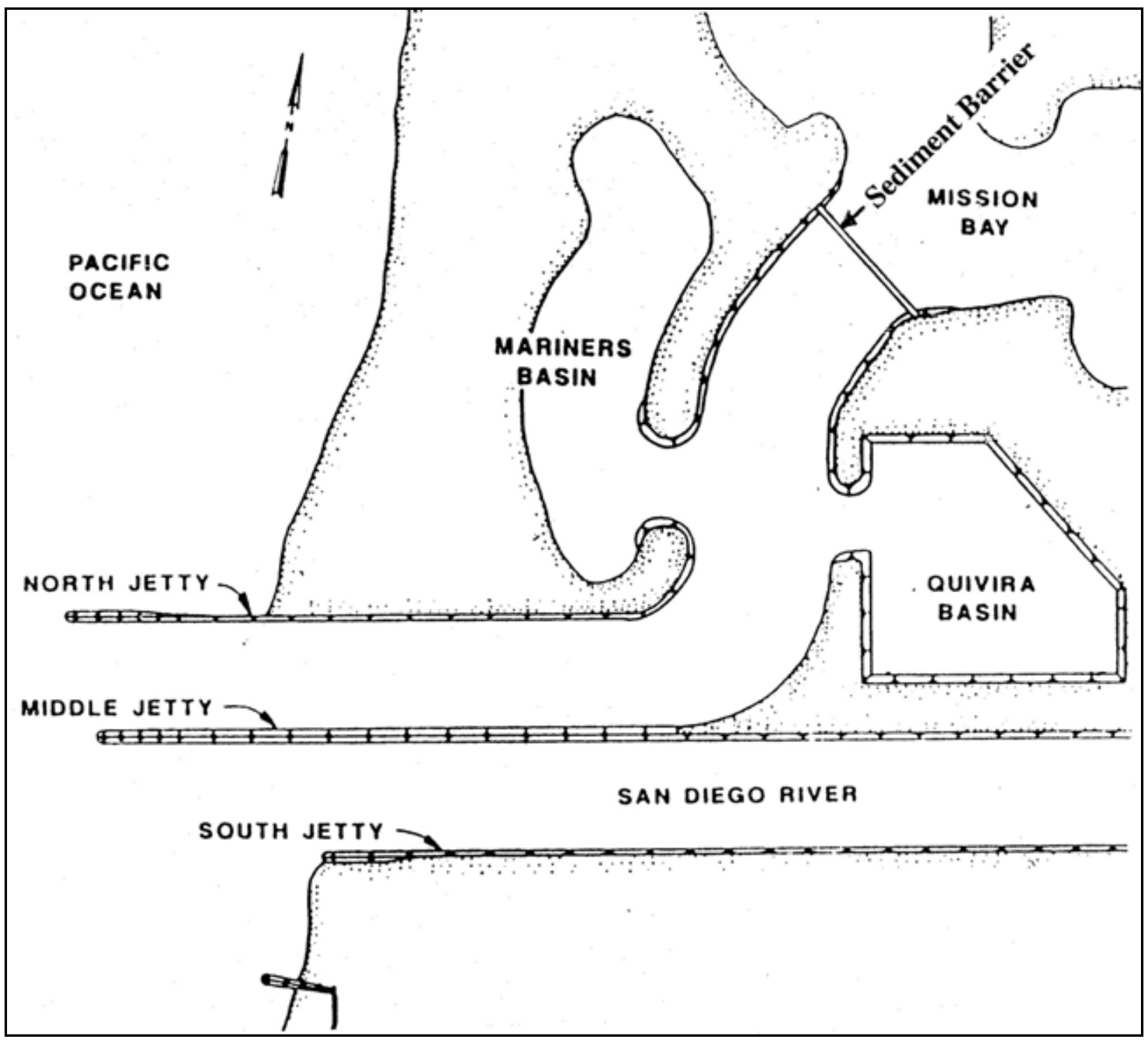

Figure 27. River flow diversion at San Diego River, CA

An enclosed small-craft, half-tide harbor at Dillingham, AK, shoaled at a high rate of about $2 \mathrm{~m} /$ year since it was constructed in 1960-1961 (Smith 1984). This enclosed harbor has a diurnal tidal range of 5 to $6 \mathrm{~m}$ with a suspended sediment concentration on the order of $1,000 \mathrm{mg} / \mathrm{L}$. Diurnal tidal ranges of 5 to $6 \mathrm{~m}$ in Bristol Bay and 6 to 9 meters in Cook Inlet produce tidal currents exceeding 2 to $3 \mathrm{~m} / \mathrm{sec}$. Therefore, a large concentration of sediment remains in suspension. Since the large tidal range precluded a channel and basin that provided access at all stages of tide, a rock sill was placed in the 15 -m-wide creek channel with a top elevation of $+2.1 \mathrm{~m}$ mean lower low water $(\mathrm{mllw})$. The basin behind the sill was dredged to $+0.6 \mathrm{~m}$ mllw, providing a $1.5-\mathrm{m}$ depth inside the basin at low tide for flotation of small vessels. This sill elevation allowed navigation access in and out of the harbor approximately 46 percent of the time. 
Modifications to existing facilities were necessary for harbor expansion in order to accommodate 300 or more fishing vessels in Dillingham Harbor. In addition to increasing the area of the existing basin, one option consisted of lowering the entrance sill, which would allow more efficient flow of traffic and meet the required objective. However, it would also allow an additional volume of silt-laden water in the harbor area resulting in increased maintenance dredging. Therefore, the option of lowering the sill was ruled out.

The following options were considered to reduce the volume of siltation.

a. Removable float system. A float system to serve as small-craft berths consisting of heavy-duty, barge-like steel floats that can endure repeated seasonal removal. These units connect in such a way that a minimum number of pilings are required to hold them in position. A raft of two barges is sufficient to carry a small crane for placing and removing pilings. The float arrangement accommodates the periodic work of the dredge between fingers. Individual slips are not provided due to the transient nature of the Dillingham fleet. This float system will accommodate 100 gillnetters moored singly. Multiple berthing three abreast will accommodate 300 vessels, which meets the project requirement.

b. Entrance channel closure structure. The most unusual feature planned for the harbor was construction of a steel closure structure in the entrance channel. This structure incorporates a 50 -ft-wide sill at $+4 \mathrm{ft}$ mllw and allows the basin to be closed off from the silty water of the bay during winter months. Closure from October through April was estimated to reduce the annual sedimentation to at least 60 percent of what would otherwise occur. This reduction was vital in conceiving a plan with annual maintenance dredging requirements less than the permissible maximum quantity of $120,000 \mathrm{cu}$ yd. The structure includes a cathodic protection system and a system of steam thawing pipes for removal of the steel stoplogs each spring. The banks adjacent to the offshore side of the structure are to be protected from erosion by a rock revetment.

c. Hydraulically optimized basin geometry. Several layout plans were evolved for an expanded harbor taking into account the maintenance difficulties and cost benefit considerations for each. Tidal circulation in the expanded basin under various configurations was numerically simulated for study. The study concluded that neither spur dikes, variable bottom elevations, nor two entrances showed any distinct advantages. None of the configurations tested maintained velocities sufficient to prevent the settling of $0.006-\mathrm{mm}$-size particles present in the tidal water at site. The study was inconclusive because it did not offer any recommendation of structures for reducing shoaling.

\section{Multiple Structures at Ninilchik Harbor, AK}

Ninilchik Harbor, located on lower Cook Inlet, AK, has a diurnal tidal range of 6 to $9 \mathrm{~m}$ and tidal currents that exceed 2 to $3 \mathrm{~m} / \mathrm{sec}$. The following measures were considered/tried at the site for reducing sedimentation (Smith 1984): 
- A sediment trap was excavated upstream of the basin.

- French drains were installed to stabilize basin slopes.

- Basin contours were smoothed

- Installation of hydraulic diversion dikes was considered.

- A closure structure was investigated.

None of these measures were found to be effective or economical.

Various configurations of breakwater alignment, sill elevation, and basin shape were investigated. It was concluded that maintenance dredging would be much less at a new site on the south side of Cook Inlet because the bank sloughing and the contribution of river sediment directly into the harbor would no longer exist. Unfortunately, the project was abandoned in October 1983 because an affordable means to provide necessary armor rock for breakwater construction could not be provided.

\section{Hudson River Channel}

The annual maintenance dredging in 1965 in the lower 11 miles of the Hudson River was about 1.6 million cu yd for the Federally maintained navigation channels and 3.0 million cu yd for the privately owned pier slips. Several plans were considered to reduce shoaling in this reach including channel realignment, sediment basin, dikes, closure gates, and cross-section enlargement. A comprehensive hydraulic model, which correctly reproduced tides, tidal currents, density currents, and shoaling in the entire New York Harbor complex, was used to study these plans. Sedimentation basin plans were intended to encourage deposition of shoal material in the basins and thus reduce shoaling of the channels and pier slips. Reduction in maintenance dredging cost is achieved by either (a) decreasing the frequency of dredging and thereby reducing the unit cost or (b) concentrating shoaling at more favorable locations from the standpoint of dredge material disposal, which would also reduce unit cost. The conclusions of the study (Simmons and Bobb 1965) were as follows.

- A dike extending from the New Jersey shore and enclosing shoal area 6 would not materially reduce shoaling in area 6 as intended, and would cause significant increase in shoaling elsewhere, particularly in the maintained slips.

- Significant reductions in shoaling rates in existing shoal areas could be effected by realigning or shifting the deep natural channel from the Manhattan side of the Hudson River to the New Jersey side.

- Closure of the Harlem River to ebb flow, combined with enlarging the Hudson River cross section at the George Washington Bridge, would encourage flushing of the Hudson River during ebb flows and thus result in shoaling reduction throughout the problem area. Construction of a control structure was recommended. 
- A practical means for reducing annual shoaling rates in pier slips was not found.

- It was recommended that potential benefits of dredging a sediment trap in the upstream end of the $30-\mathrm{ft}$ channel should be evaluated. Construction and operation of such a trap would probably not be economical if periodic maintenance of the trap were performed by conventional hopper dredge. However, it is possible that the demand for fill material for land reclamation, which might be obtained from the trap by the pipeline dredge, may eventually make such a scheme economically feasible.

\section{Lower Hudson River, NY}

A major item of maintenance, and a deterrent to the full use of the Hudson River frontage for maritime purposes, has been the heavy shoaling that occurs in the channel and adjacent slips of the lower estuary. Investigations to find a solution to this problem included determination of: the sources of sedimentation, the characteristics of the freshwater and saltwater components of flow within the estuary, the quantity of shoaling which occurs, and the fundamental principles affecting the sedimentation process. It was concluded that shoaling is caused by:

- Flocculation of fine sediments caused by favorable site conditions.

- Constriction in the cross-sectional area of the river at George Washington Bridge.

- Differential depths between the natural channel on the New York shore versus the man-made channel on the New Jersey shore.

Because of the nonanalytic character of the complex factors involved in this problem, two hydraulic models were used to investigate a number of possible solutions (Duke 1961). About 20 plans and variations were tested on the models:

- Provision of sedimentation basins in the existing navigation channels.

- Realignment of the deep-water channel by construction of dikes.

- Modification of channel geometry upstream and downstream of the George Washington Bridge.

- Closure of flow from Harlem River.

The following conclusions were drawn from the model studies:

a. Out of the sedimentation basins tested, three appeared most promising. Each had a volumetric capacity of 4 million cu yd and was about 6,000 to 7,000 ft long, and 50 to $60 \mathrm{ft}$ deep. The basins trapped enough sediment to result in reduction of shoaling in the present areas from 10 to 70 percent; however, the total material deposited in the basins and elsewhere increased by about 50 percent. Therefore, the basins are not a permanent solution, but they offer a relatively cheap initial cost solution. 
$b$. Construction of a wing dike downstream of Fort Lee for enclosing the areas of heaviest shoaling was not effective. It prevented sediment from entering the problem area from upstream. However, the tidal flushing in the enclosed area was drastically reduced, resulting in a 50-percent increase in shoaling. This option was ruled out.

c. Increasing the cross-sectional area of channel at George Washington Bridge and constricting the channel downstream by providing a dike resulted in a 50-percent reduction of sediment deposition in all shoal areas except one.

d. Closure of the Harlem River by constructing a movable gate at its junction with Hudson River would result in a 20 percent reduction in shoaling of project channel. However, this proposal was ruled out in view of its adverse effect on navigation. 


\section{Design Methods}

\section{Standard Guidelines}

The design of the structures should consider the effects of the structures on currents existing in the reach, the movement of sediment, and the effects of the resulting currents on navigation. The design of spur dikes must consider parameters such as channel alignment, contraction, dike length, dike height, crest width, side slopes, end slopes, dike angle, dike spacing, stone size, bank paving, and method of construction. Standard design guidelines for dike design are given in Engineer Manual 1110-2-1611 (Headquarters, U.S. Army Corps of Engineers 1997). Another good reference for designing dikes is the book written by Pilarczyk (1998).

\section{Physical Models}

Physical models have been the most successfully used tool over the past 60 years for conducting studies for designing levees and dikes for river training works needed for flood and sediment control. However, physical models are labor-intensive and time-consuming, require large space for construction, have limitations due to vertical distortion, and are impractical for long duration runs. When the geometry and hydraulics are correctly reproduced, the physical processes are automatically reproduced correctly, which is a great advantage in using physical models. Hundreds of projects have been studied at various hydraulic laboratories around the world using physical modeling techniques. A few examples of projects that have been studied in the United States include:

- Savannah Harbor (U.S. Army Engineer Waterways Experiment Station 1961, 1963).

- Delaware City Channel (Bobb 1965).

- Delaware River Channel fixed bed model study (Bobb 1967).

- Mississippi River movable bed model (Franco et al. 1970).

- Arkansas River Lock and Dam movable bed model (Foster et al. 1983).

- Ohio River Lock and Dam (Franco et al. 1983).

- St. Louis Harbor movable bed model (Franco 1972). 


\section{Numerical Models}

The use of physical models has steadily declined over the past decade and has been replaced by numerical models. Numerical models eliminate the disadvantages of physical models described above; however, they involve several empirical coefficients in describing and simulating physical processes through mathematical equations. Values of such coefficients need to be determined by using field data during validation. An example of a numerical model project is the Redeye Crossing Reach, Mississippi River.

Redeye Crossing is located on the lower Mississippi River above Head of Pass, about 3 miles downstream of the I-10 highway bridge at Baton Rouge, LA. The existing conditions with a 13.7-m-deep channel require about 3 million cu yd of dredging annually to maintain the 40-ft-deep navigation channel. A 45-ft-deep channel proposed for the area would drastically increase the annual dredging requirements. Pokrefke et al. (1995) reported results of numerical and physical model studies that evaluated effectiveness of proposed spur dikes at Redeye Crossing in reducing maintenance dredging requirements.

Numerical model results indicated that a dike plan consisting of six dikes on the left-descending bank with crest elevations of 2, 2, 7, 7, 7, and $7 \mathrm{ft}$ with reference to the National Geodetic Vertical Datum (NGVD), respectively, from upstream to downstream were determined to be the most effective. It was concluded that this dike field would reduce channel shoaling by about 90 percent for the 43-year-average annual hydrograph and 50 to 60 percent for the 1990 hydrograph.

A physical movable-bed model study was also conducted on the same dike plan consisting of six dikes on the left-descending bank. It was concluded that this plan would reduce channel shoaling by about 60 percent for the 43 -yearaverage annual hydrograph and about 27 percent for the 1982-83 hydrograph.

These two differing results indicate that numerical model estimates are optimistic and physical model estimates are conservative. 


\section{Numerical Simulations}

Since estuarine sediments consist mostly of fine silt, clays, and organic matter, they are transported primarily in suspension. These sediments continue to remain in suspension even under a relatively small flow-induced shear stress. In areas such as navigation channels, which are deeper than the surrounding bed levels, flow velocity decreases due to locally increased cross section. In addition, there may be zones of low velocity where suspended sediments tend to deposit. Eddies are also zones where fine sediment recirculates leading to flocculation and excessive deposition. Eddies can sometimes be eliminated by constructing structures in the vicinity of the eddies.

\section{Charleston Harbor}

Schematic numerical simulations were conducted as a part of a study to examine this aspect in Charleston Harbor. A numerical grid was constructed at the Coastal and Hydraulics Laboratory, WES. The numerical model dynamically calculated eddy viscosities, important to eddy formation. Realistic boundary conditions based on field data were available. Model flow velocity could be easily changed by varying river inflows. Therefore, this geometrical layout and grid were used to conduct some schematic numerical hydraulic simulations of dike fields.

\section{Ashley River, Charleston, SC}

A 1,500-ft stretch of Ashley River and adjacent land was found to be contaminated. In consultation with the U.S. Environmental Protection Agency, the decision was made to cover and cap the site by allowing natural sediment to deposit over the area of potential concern. Two structural alternatives were considered: a dike field and a sheet pile wall enclosure with weirs. Numerical simulations were conducted at ERDC for examining the option of the dike field.

Figure 28 shows the flow pattern with a six-dike field. It may be noted that a large and strong eddy formed inside the central part of the dike field. The other areas inside dikes had weaker and smaller eddies. Figure 29 shows a field with nine dikes and the results obtained with a numerical sediment model. It may be seen that considerable sediment deposition took place in the bank area in the vicinity of the dike field. It was thus demonstrated that sediment deposition could be induced by providing a dike field. 


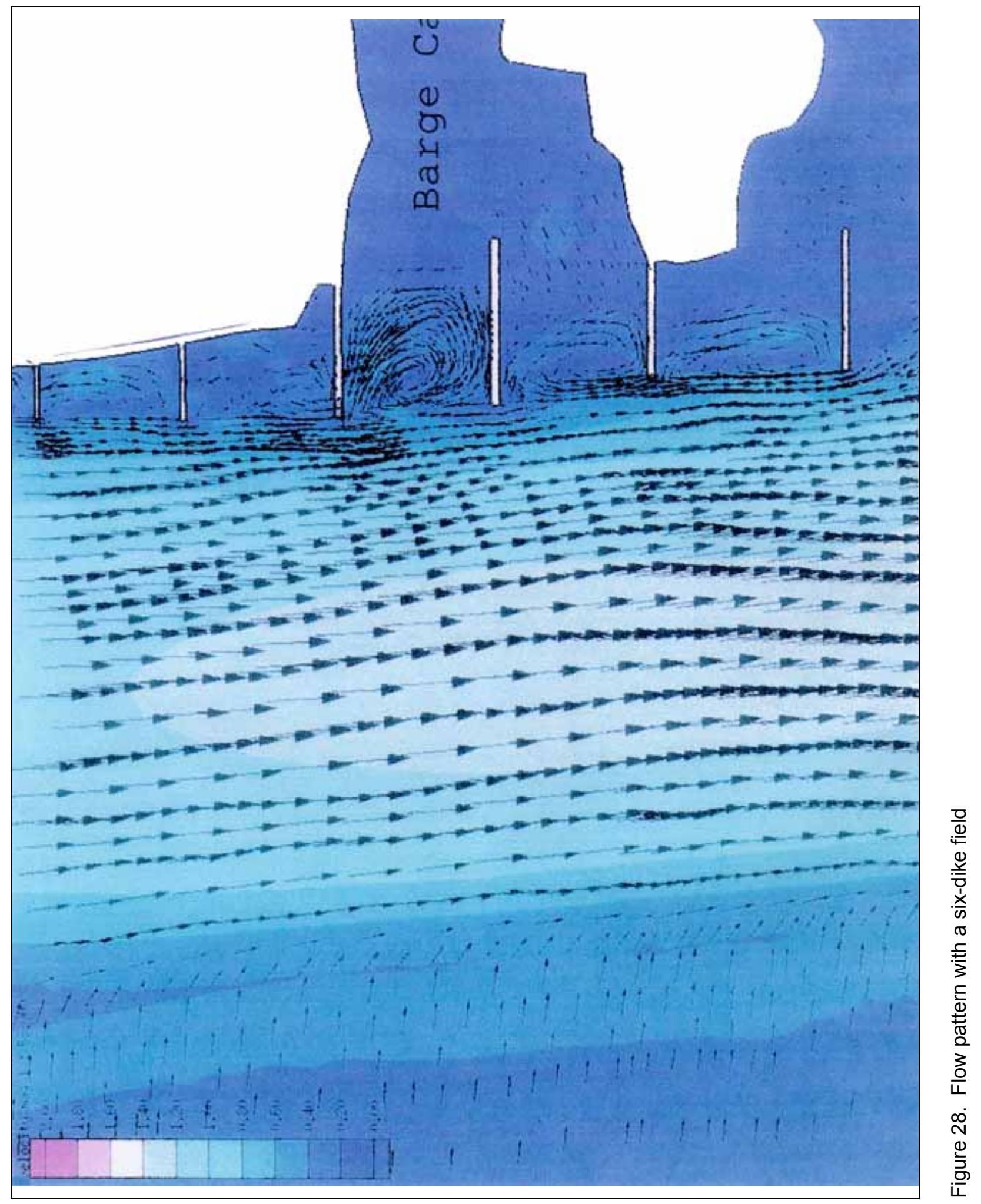




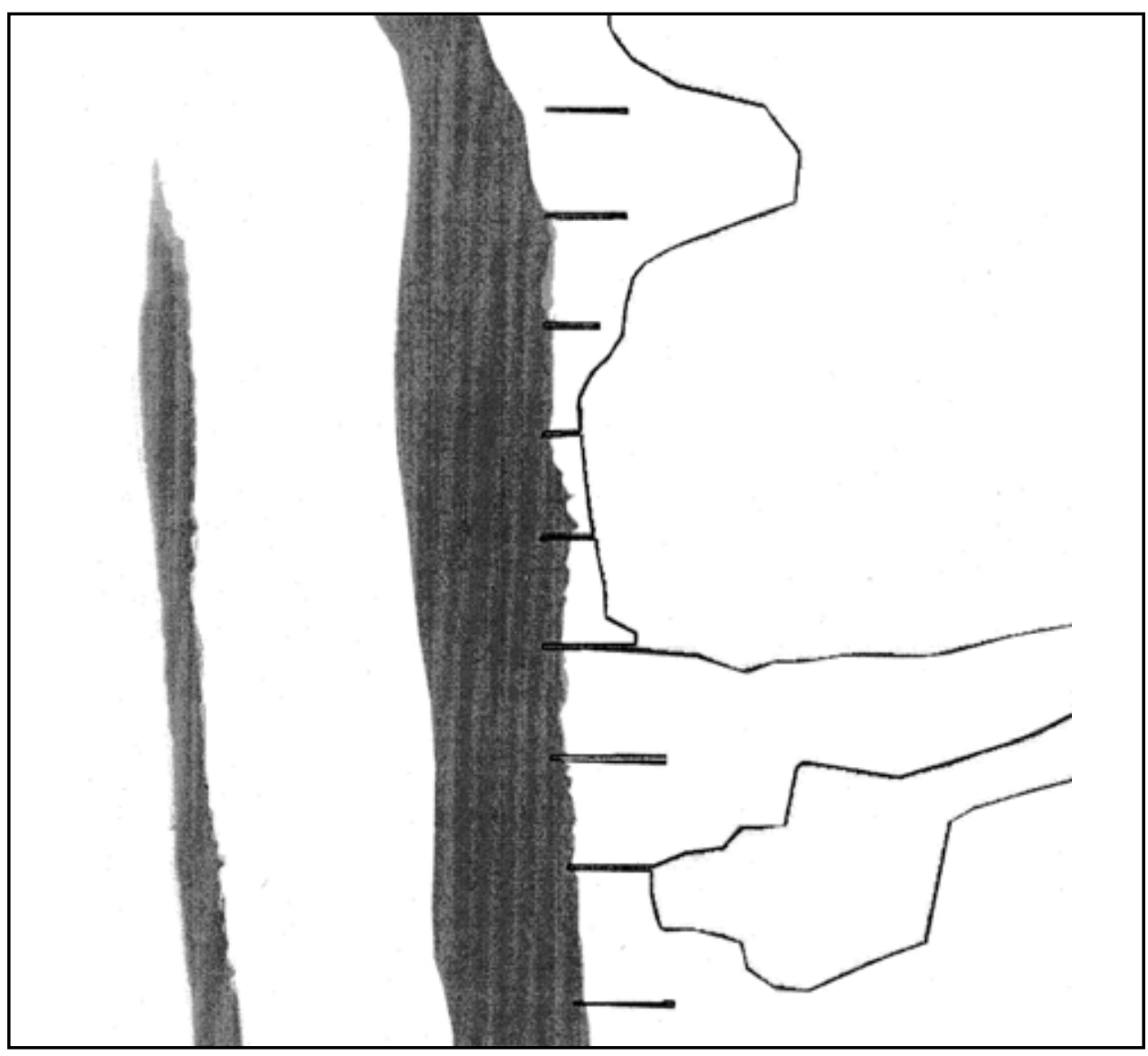

Figure 29. Sediment accumulation due to a nine-dike field

Additional qualitative studies were conducted using the same grid that was used for the Ashley River study. A different reach of Ashley River was selected and the effect of two dikes (Dike 1 on the north and Dike 2 on the south) was examined. The bathymetry of this reach and the tidal curve used as the boundary condition are shown in Figures 30 and 31, respectively. Flow patterns at some pre-selected stages of tidal curve were obtained. The selected tidal stages, shown in Figure 32, show that eddy formed during both flood and ebb.

Eddy formation started at Dike 1 at $26.5 \mathrm{hr}$ (Figure 33). At $27 \mathrm{hr}$ an eddy was fully formed at the strength of ebb stage of tide (Figure 34). After removing the two dikes, the eddy was practically eliminated at the same stage $(27 \mathrm{hr})$ of tide (Figure 35). At $27.5 \mathrm{hr}$ the eddy shifted away from the bank (Figure 36).

During flood stage eddies formed at Dike 2. An eddy was fully formed at $33 \mathrm{hr}$ (Figure 37). After removing both dikes, this eddy disappeared at the same stage (33 hr) of tide (Figure 38). With the two dikes in place, the eddy shifted northward at $33.5 \mathrm{hr}$ (Figure 39).

The above demonstration shows that dikes can induce eddy formation, which in turn might result in sediment deposition under favorable conditions. Dike design parameters such as length and spacing have a considerable influence on flow field. 


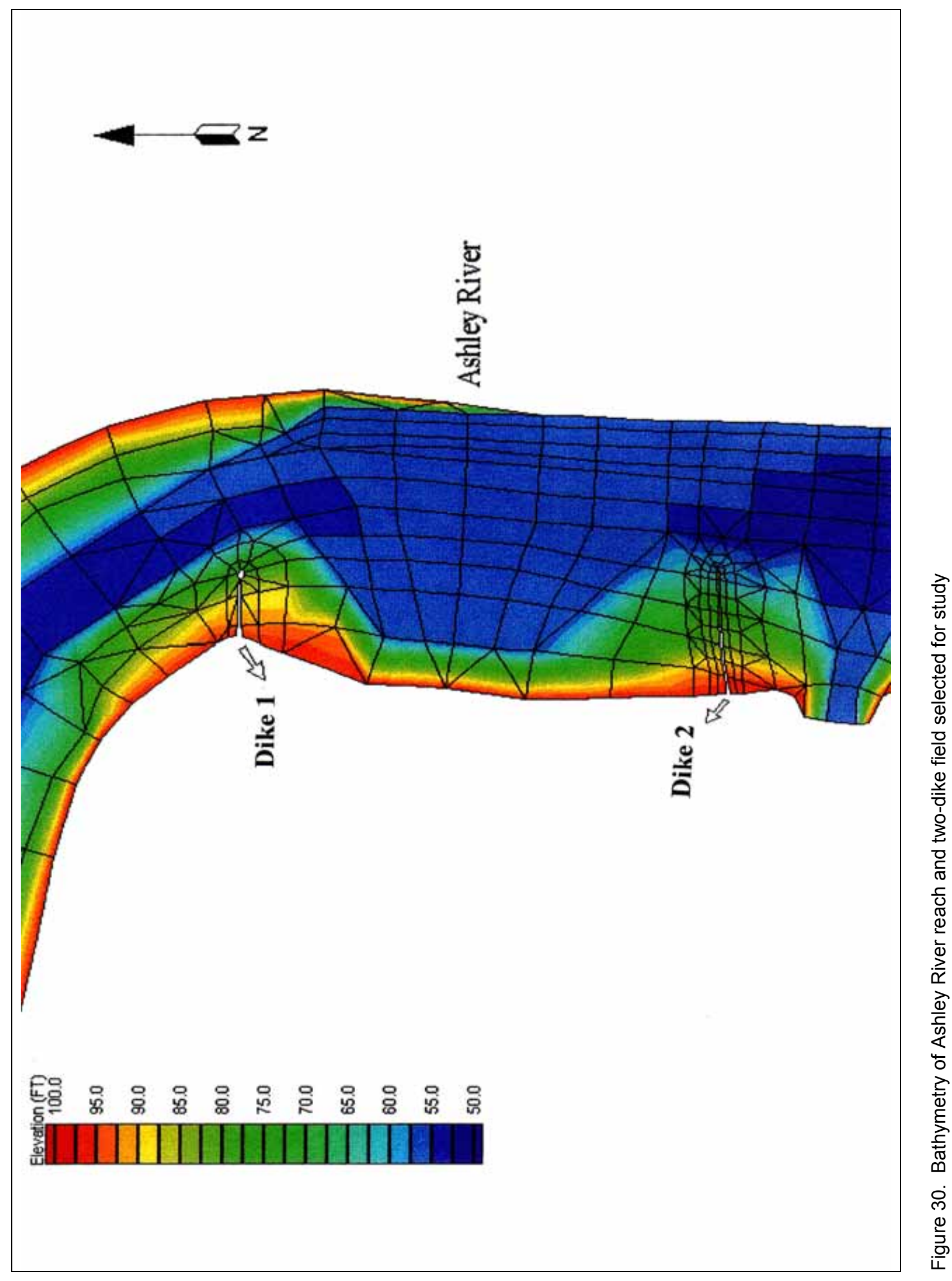




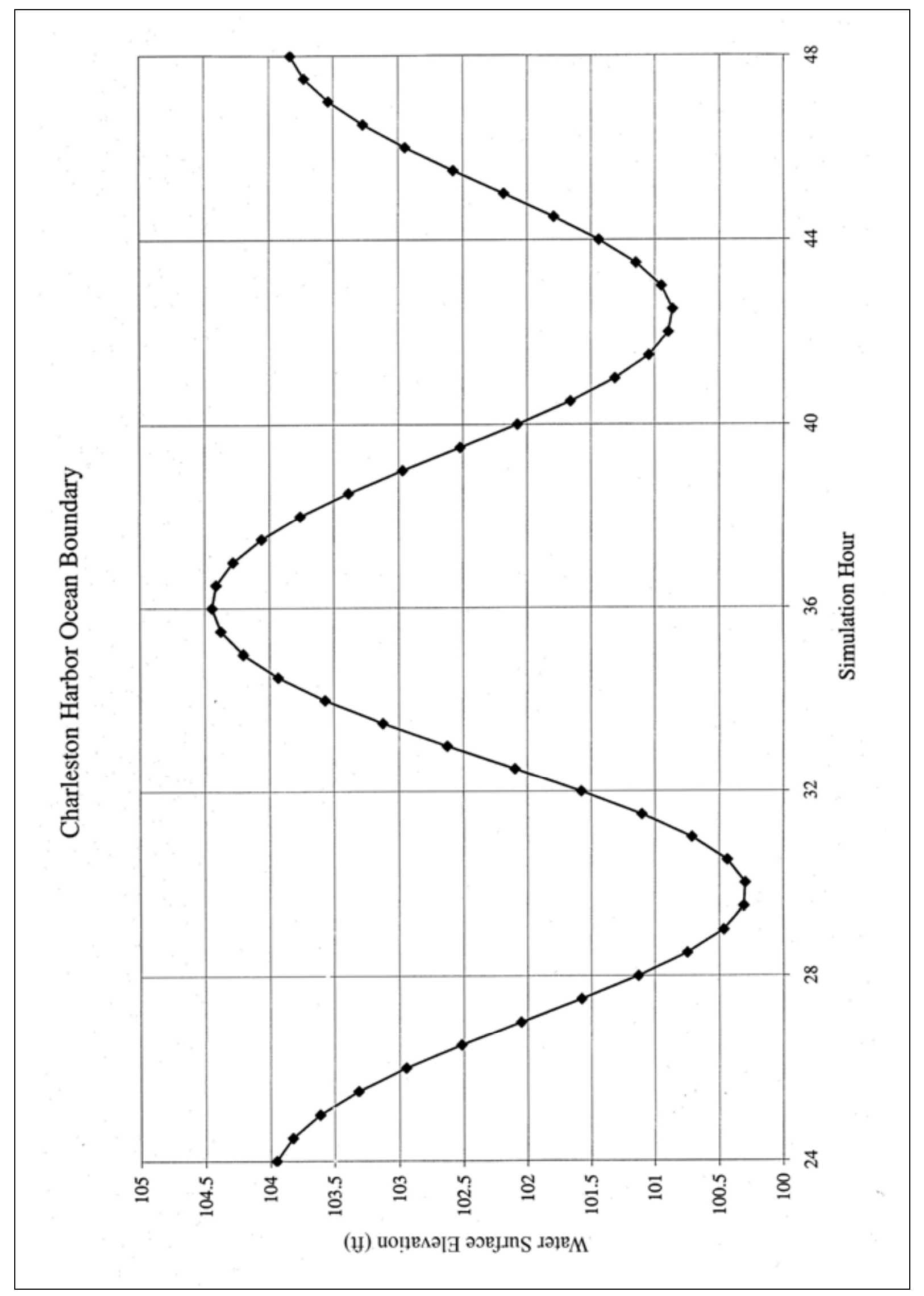

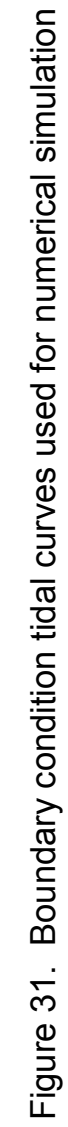




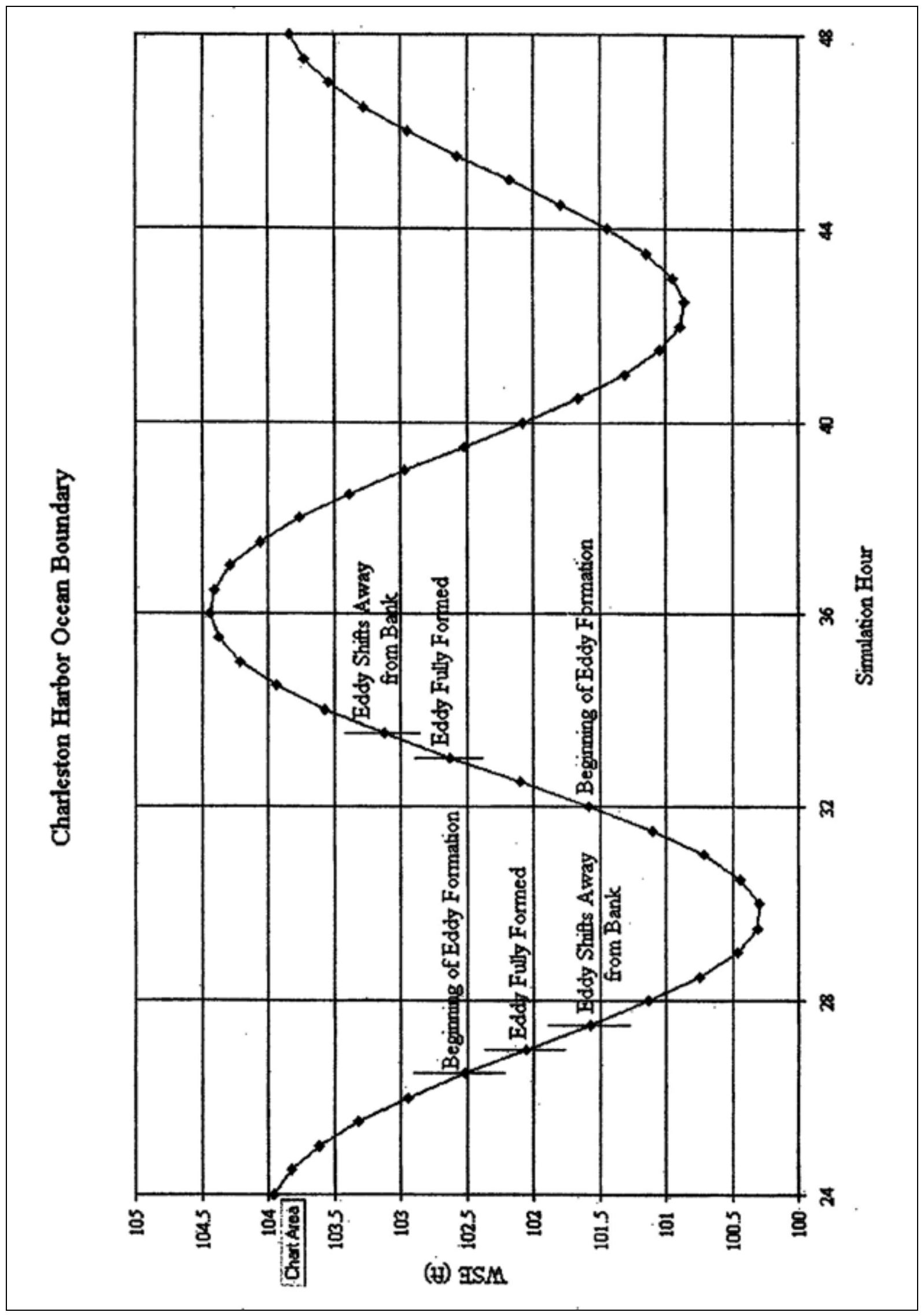

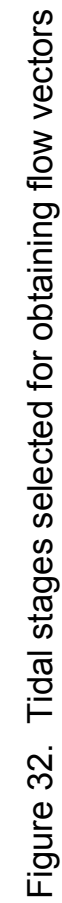




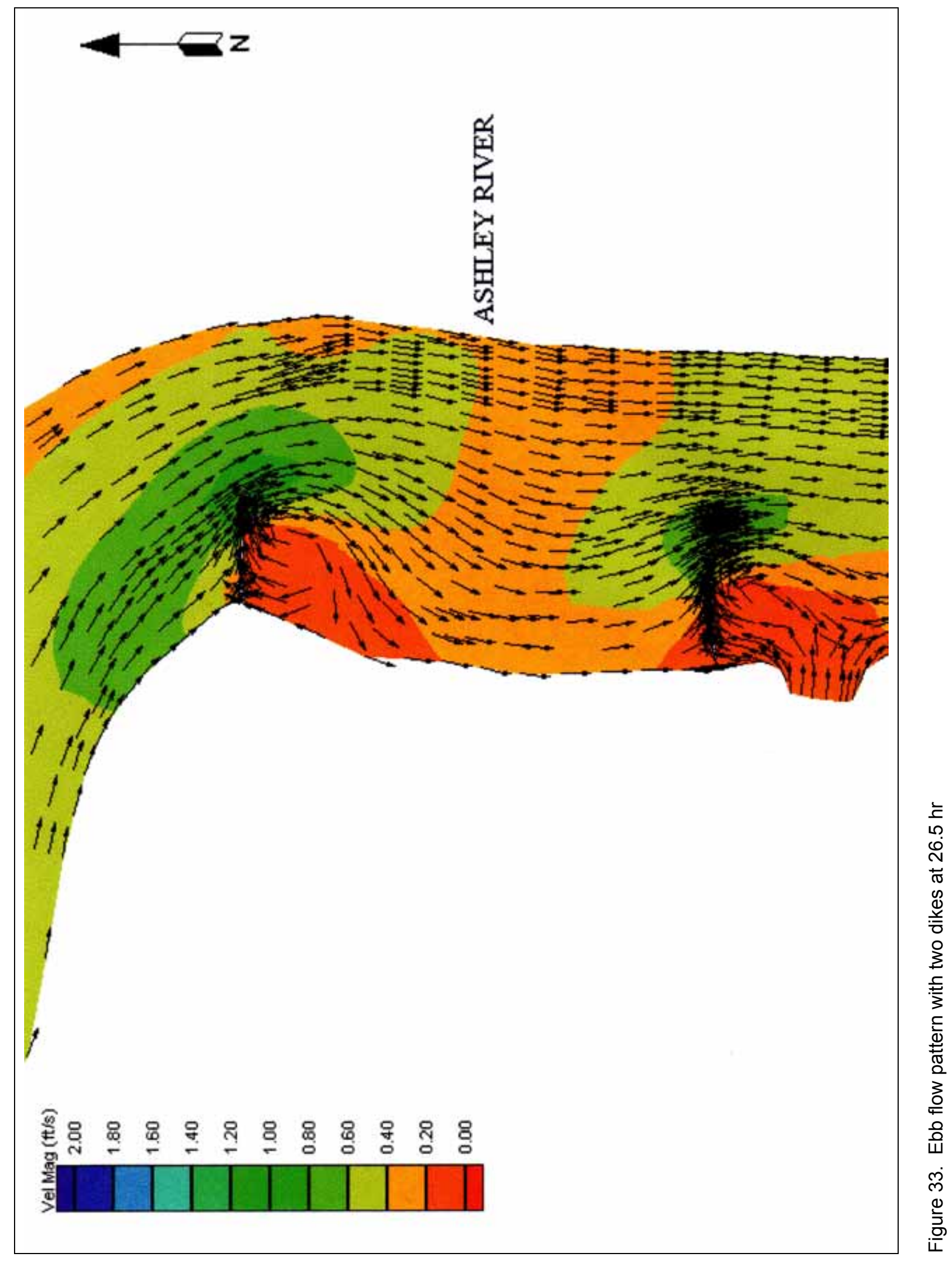




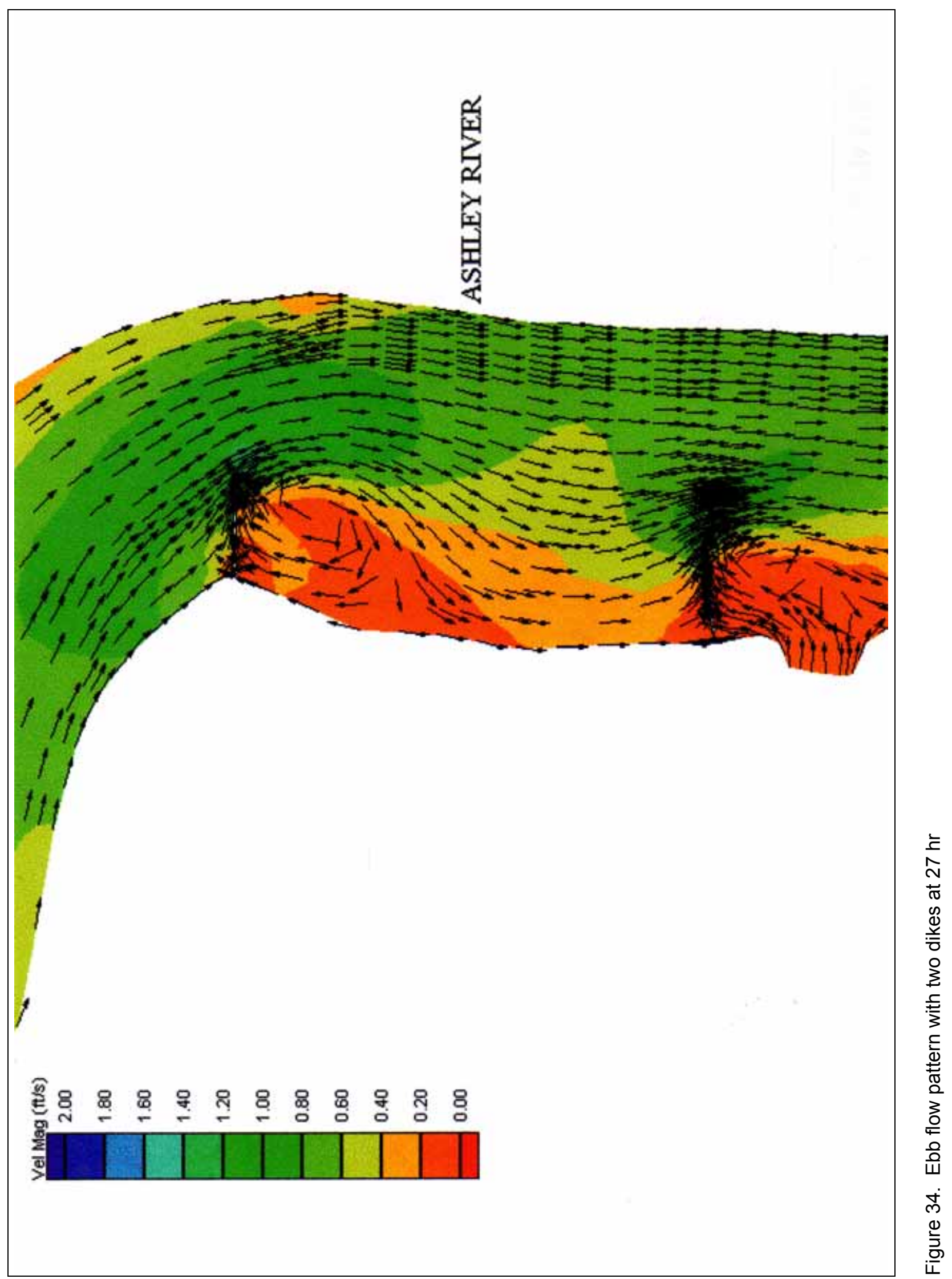




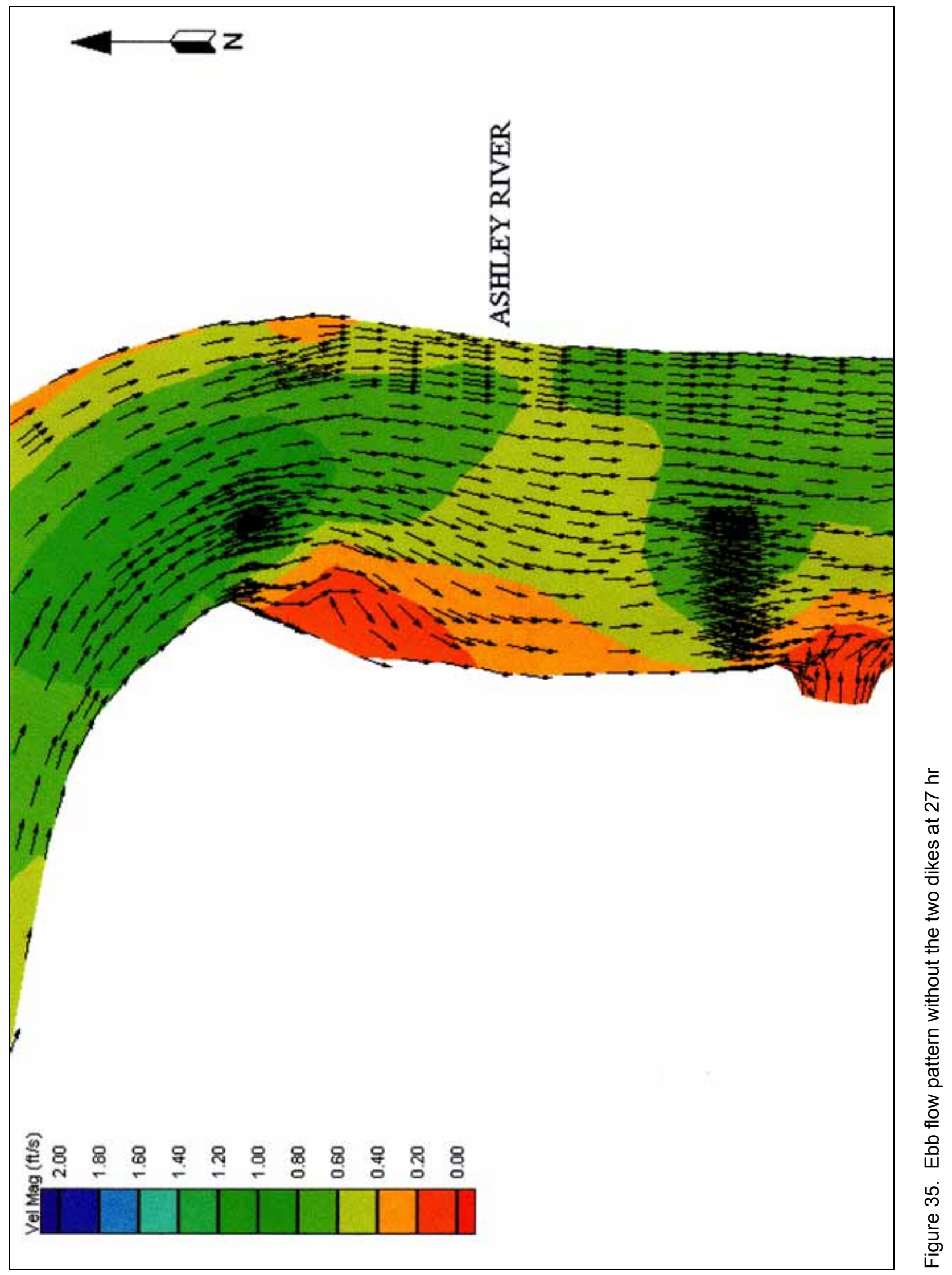




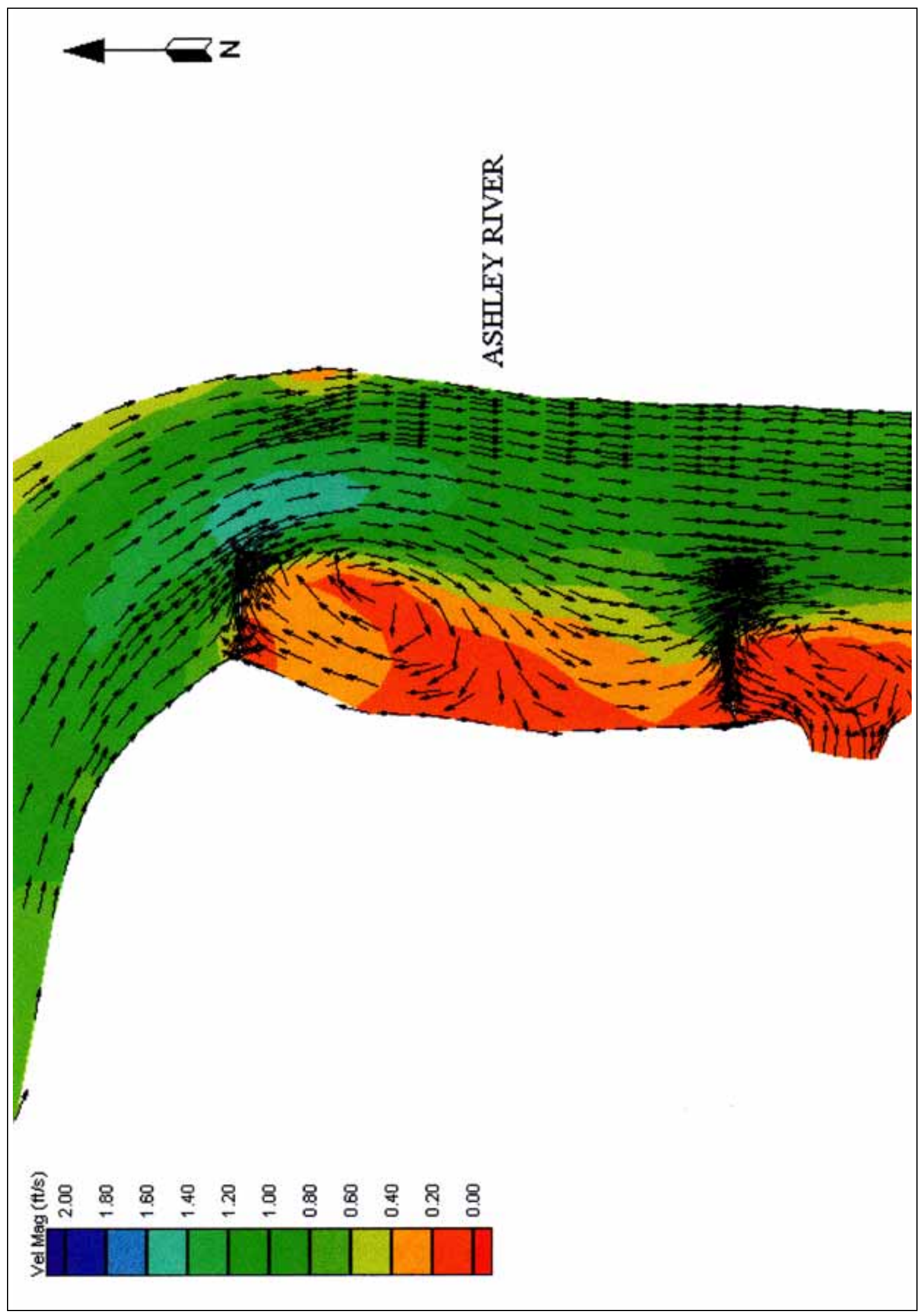

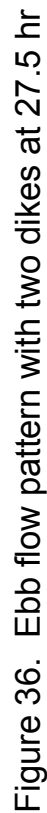




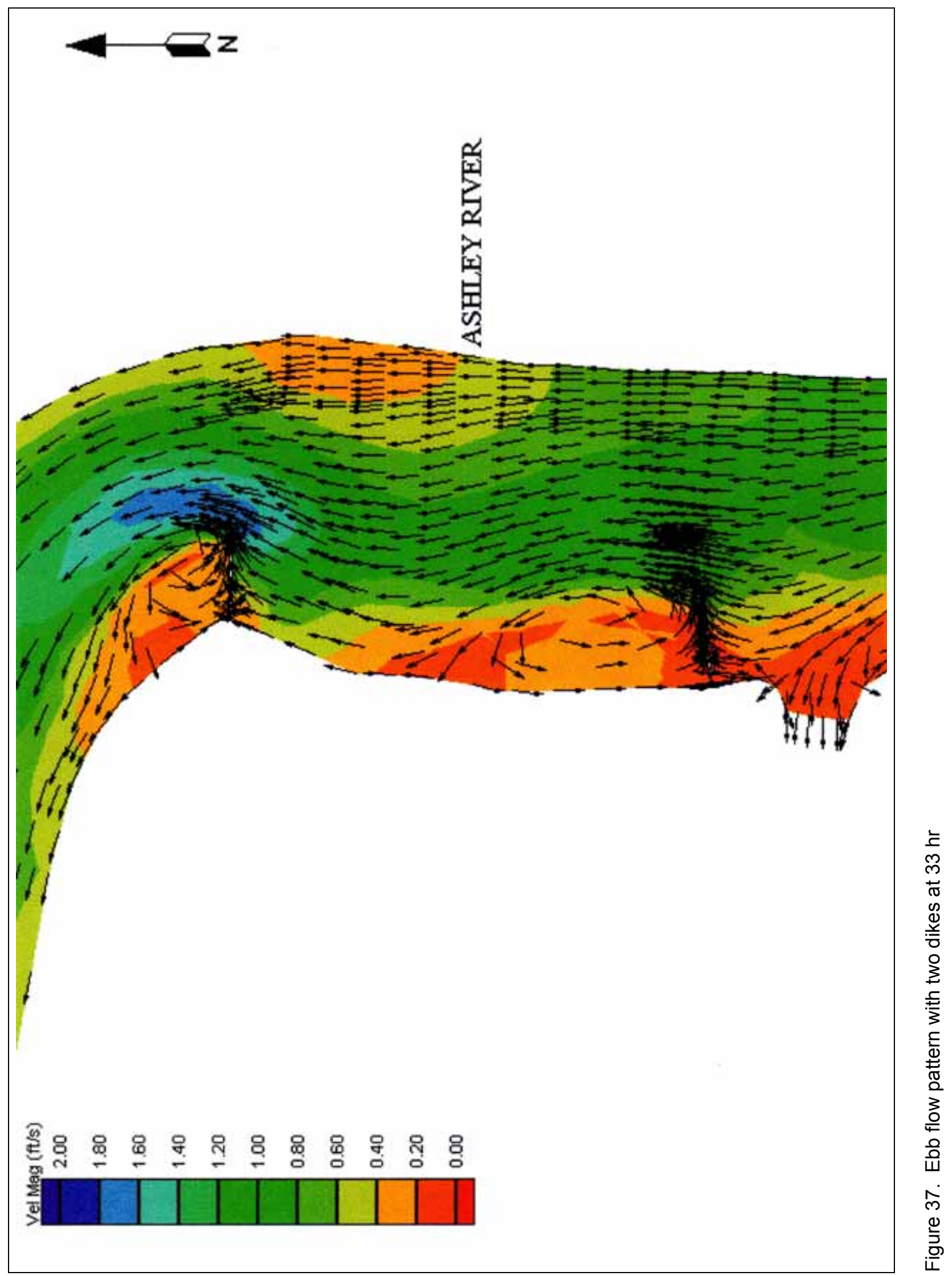




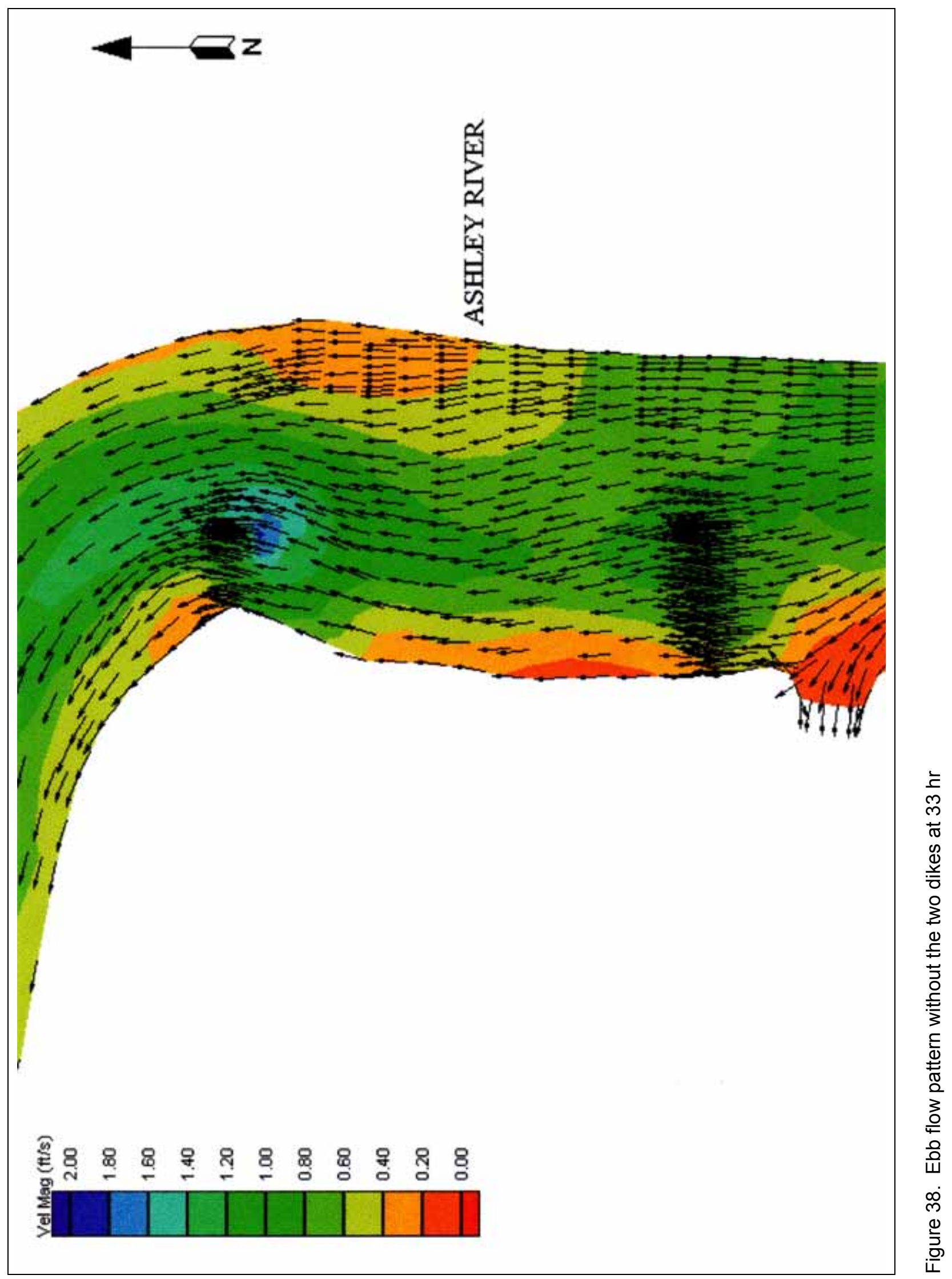




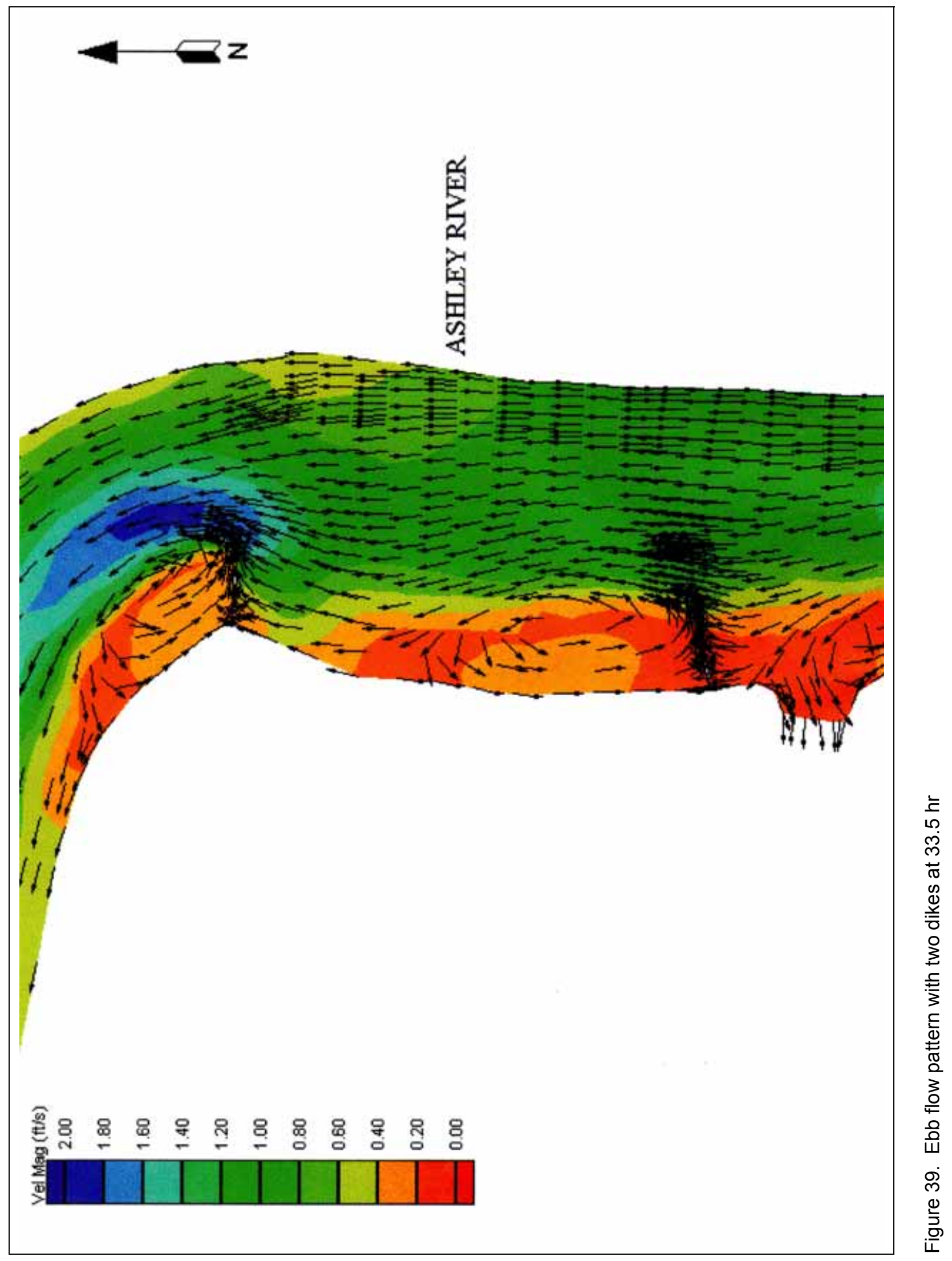




\section{Concluding Remarks}

Several studies have been conducted all over the world during the past century for inventing suitable structural methods to reduce shoaling in navigation channels and harbors. Literature review on some of such studies described in this report leads to the following conclusions.

a. Navigation channel shoaling is a global problem. Periodic removal of accumulated sediment from the channel and harbor area is expensive and time-consuming. Several structural methods have been invented to reduce sediment deposition in navigation channels.

$b$. Structural remedies are mostly site-specific and should not be adopted without examining their applicability at a site under consideration.

c. A large number of parameters must be taken into account while selecting a set of technically feasible and economically viable options.

d. Dikes may be used either to reduce shoaling or to induce shoaling depending upon site requirements. Therefore, their choice and layout need to be selected carefully.

$e$. Detailed studies in the form of physical modeling, numerical modeling, field data collection and analysis, and examination of successful measures adopted at other sites should be undertaken to select the best possible option for a given site under consideration. 


\section{References}

Alexander, M. P. (1993). "Use of a current deflector wall for eddy-generated shoaling in Kohlfleet Harbor, Germany," The REMR Bulletin 10(2), U.S. Army Engineer Waterways Experiment Station, Vicksburg, MS.

Bailard, J. A., Dellaripa, F., and Flor, T. H. (1986). "Sedimentation control: Reducing the need for dredging," The Military Engineer, 438-441.

Bobb, W. H. (1965). "Effects of proposed dikes and sediment traps on shoaling and currents in tidewater's Delaware City Channels," Miscellaneous Paper No. 2-723, U.S. Army Engineer Waterways Experiment Station, Vicksburg, MS.

. (1967). "Results of hydraulic and shoaling studies in Marcus Hook - Schuylkill reach of Delaware River," Miscellaneous Paper No. 2-887, U.S. Army Engineer Waterways Experiment Station, Vicksburg, MS.

Bottin, R. R. (1982). "Design for flood control, wave protection, and prevention of shoaling, Rouge River, Oregon," Technical Report No. HL-82-18, U.S. Army Engineer Waterways Experiment Station, Vicksburg, MS.

Bottin, Jr., R. R., and Chatham, Jr., C. E. (1975). "Design for wave protection, flood control, and prevention of shoaling, Cattaraugus Creek Harbor, New York," Technical Report No. H-75-18, U.S. Army Engineer Waterways Experiment Station, Vicksburg, MS.

Chatham, C. (1981). "Prevention of shoaling at Port Orford, Oregon," Journal of the Hydraulics Division, ASCE, 107(HY11), 1303-1316.

Committee on Tidal Hydraulics. (1966). "Charleston Harbor, South Carolina, A review of certain aspects of plans for rediverting Santee-Cooper power plant discharges from Cooper River," U.S. Army Corps of Engineers.

Derrick D. L., Pokrefke, T. J., Boyd, M. B., Crutchfield, J. P., and Henderson, R. R. (1994). "Design and development of bendway weirs for the Dogtooth Bend reach of Mississippi River," Technical Report HL-94-10, U.S. Army Engineer Waterways Experiment Station, Vicksburg, MS. 
Duke, C. M. (1961). "Shoaling of the Lower Hudson River," Journal of the Waterways and Harbors Division, ASCE, 87(WW1), 29-45.

Everts, C. H. (1976). "Sedimentation in a "half-tide" harbor: Part 1: Sedimentation under ice-free conditions," Assessment of the Arctic Marine Environment: Selected Topics, Institute of Marine Science, University of Alaska, Fairbanks, 132-160.

Foster, J. E., Noble, C. M., and Glover, J. E. (1983). "Shoaling conditions in Lock and Dam 13 Pool, Arkansas River, Hydraulic model investigation," Technical Report HL-83-20, U.S. Army Engineer Waterways Experiment Station, Vicksburg, MS.

Franco, J. J. (1972). "Shoaling conditions, St. Louis Harbor, Mississippi River," Technical Report H-72-7, U.S. Army Engineer Waterways Experiment Station, Vicksburg, MS.

Franco, J. J., Glover, J. E., and Pokrefke, T. J. (1970). "Investigation of the proposed dike system on the Mississippi River, Report number 1, BaleshedAjax Bar reach, Hydraulic model investigations," Miscellaneous Paper H-70-1, U.S. Army Engineer Waterways Experiment Station, Vicksburg, MS.

Franco, J. J., and Pokrefke, T. J. (1983). "Smithland Locks and Dam, Ohio River, Hydraulic model investigation," Technical Report HL-83-19, U.S. Army Engineer Waterways Experiment Station, Vicksburg, MS.

Gole, C. V., and Vaidyaraman, P. P. (1969). "Deepening the approach channel to the Port of Cochin," $13^{\text {th }}$ Congress of the IAHR, Proc. 3, 233-240.

Headquarters, U.S. Army Corps of Engineers. (1997). "Layout and design of shallow-draft waterways," Engineer Manual 1110-2-1611, Change 3, Department of the Army, Washington, DC.

Herb, W. J. (1980). "Sediment-trap efficiency of a multiple-purpose impoundment, Report," North Branch Rock Creek Basin, Montgomery County, MD, 1968-76.

Herbich, J. B., Darby, R., Wilkinson, G., Krafft, K., and Hert, D. (1989). "Definition of navigable depth in fine-grain sediments, Final Report," Texas A\&M Research Foundation Report, CDS Report No. 312.

Hidayat, R., Morimoto, K., Ono, N., and Irie, I. (2000). "Study of sediment behavior in channel for the countermeasure against siltation," Proceedings of the 8th Tech Ocean Symposium. 3, 571-574.

Hobson, R. D. (1982). "Performance of a sand trap structure and effects of impounded sediments, Channel Islands Harbor, California," Technical Report No. 82-4, U.S. Army Engineer Waterways Experiment Station, Vicksburg, MS. 
Hofland, B., Christiansen, H., Crowder, R. A., Kirby, R., van Leusen, C. W., and Winterwerp, J. C. (2001). "The current deflecting wall in an estuarine harbor," Proceedings of XXIX IAHR Congress, Beiging, China, Theme D. 613-621.

Holiday, B. W., Wutkowski, M. J., and Vallionos, L. (1984). "Shoaling problems and improvements Sunny Point, North Carolina," Proceedings of Conference Dredging '84, ASCE. 1, 301-310.

International Dredging Review. (1994). "LES and RCL join forces to promote current deflecting wall." 13(4), 10-11.

Jarrett, J. T. (1988). "Beach fill and sediment trap at Carolina Beach, North Carolina," Technical Report CERC-88-7, U.S. Army Engineer Waterways Experiment Station, Vicksburg, MS.

Larson, M., and Kraus, N. C. (2001), "Estimation of suspended sediment trapping ratio for channel infilling and bypassing," Technical Note CHETN-IV-34, U.S. Army Engineer Research and Development Center, Vicksburg, MS.

McAnally, W. H. (1983). "Entrance channel tests," Report 4, U.S. Army Engineer Waterways Experiment Station, Vicksburg, MS.

McCartney, B. L., Herrmann, F. A., and Simmons, H. B. (1991). "Estuary waterway projects - Lessons learned," ASCE, Journal of Waterway, Port, Coastal, \& Ocean Engineering 117(4), 409-421.

Mehta, A. J. (1986). "Characterization of cohesive sediment properties and transport processes in estuaries," Estuarine cohesive sediment dynamics, A. J. Mehta, ed., Springer-Verlag, New York, 290-325.

Melton, B. K., and Franco, J. J. (1979). "Shoaling in harbor entrances," Technical Report HL-79-5, U.S. Army Engineer Waterways Experiment Station, Vicksburg, MS.

Mueller, D. S., Maggio, D. M., and Pokrefke, T. J. (1992). "Red River waterway, Lock and Dam No. 4, Report 3, Sediment conditions, Hydraulic model study," Technical Report HL-90-2, U.S. Army Engineer Waterways Experiment Station, Vicksburg, MS.

National Research Council. (1987). "Sedimentation control to reduce maintenance dredging of navigational facilities in estuaries," Report and Symposium Proceedings, National Academy Press, Washington, DC.

Navigation Data Center. (2005). "Data on maintenance dredging," at http://www.iwr.usace.army.mil/ndc/ 
Nickles, C. R., Pokrefke, T. J., and Glover, J. E. (1985). "Buck Island reach, Mississippi River, Hydraulic model investigation," Technical Report HL-852, U.S. Army Engineer Waterways Experiment Station, Vicksburg, MS.

Parchure, T. M. (1978). "Movable bed model studies for Visakhapatnam Outer Harbor Project," Proceedings of 47th Annual Research Session of Central Board of Irrigation and Power, India.

. (2001). "Wave-induced sediment resuspension near the shorelines of the upper Mississippi River," Technical Report ENV 20, U.S. Army Engineer Research and Development Center, Vicksburg, MS.

Parchure, T. M., Brown, B., and McAdory, R. T. (2000). "Design of sediment trap at Rollover Pass, Texas," Technical Report ERDC/CHL TR-00-23, U.S. Army Engineer Research and Development Center, Vicksburg, MS.

Parchure, T. M., Sarruff, S., and Brown, B. (2001). "Desktop study for shoaling prediction in Corpus Christi navigation channel, Texas," Technical Report ERDC/CHL TR-01-30, U.S. Army Engineer Research and Development Center, Vicksburg, MS.

. (2002). "Desktop study for La Quinta Project; Shoaling prediction in La Quinta navigation channel and effect of a barrier on siltation in extended La Quinta channel," Technical Report ERDC/CHL TR-02-19, U.S. Army Engineer Research and Development Center, Vicksburg, MS.

Parchure, T. M., and Teeter, A. M. (2002a). "Lessons learned from existing projects on shoaling in harbors and navigation channels," Technical Note, CHETN XIV-5, U.S. Army Engineer Research and Development Center, Vicksburg, MS. http://chl.wes.army.mil/library/publications/chetn/pdf/chetnxiv5.pdf

. (2002b). "Potential methods for reducing shoaling in harbors and navigation channels," Technical Note, CHETN XIV-6, U.S. Army Engineer Research and Development Center, Vicksburg, MS. http://chl.wes.army.mil/ library/publications/chetn/pdf/chetn-xiv6.pdf

Patterson, G. G. (1983). "Effect of the proposed Cooper River rediversion on sedimentation in Charleston Harbor, South Carolina," Water Resources Investigations Report 83-4198, U.S. Geological Survey and U.S. Army Engineer District, Charleston.

Pettweis, M., and Sas, M. (1999). "On the sedimentation of mud in access channels to the Harbor of Antwerp," PIANC Bulletin 101, 53-58

Pilarczyk, K. W., ed. (1998). Dikes and revetments, design, maintenance and safety assessment. Pub. A. A. Balkema, Rotterdam, The Netherlands

Pinkard, C. F. (1995). "Channel realignment on the Red River Waterway," Water Resources Engineering 1, 194-198. 
Pokrefke, T. J., Nickles, C. R., Raphelt, N. K., Trawley, N. J., and Boyd, M. B. (1995). "Redeye Crossing Reach, Mississippi River," Technical Report HL95-13, U.S. Army Engineer Waterways Experiment Station, Vicksburg, MS.

Rosati, J. D., and Kraus, N. C. (1989). "Development of a portable sand trap for use in the nearshore," Technical Report CERC-89-11, U.S. Army Engineer Waterways Experiment Station, Vicksburg, MS.

. (1999). "Shoal - reduction strategies for entrance channels," Technical Note CHETN-IV-22, U.S. Army Engineer Research and Development Center, Vicksburg, MS.

Simmons, H. B., and Bobb, W. H. (1965). "Hudson River Channel, New York and New Jersey plans to reduce shoaling in Hudson River channels and adjacent pier slips," Technical Report No. 2-694, U.S. Army Engineer Waterways Experiment Station, Vicksburg, MS.

Simmons, H. B., and Rhodes, Jr., H. J. (1965). "Plans for reducing shoaling Southwest Pass, Mississippi River," Technical Report No. 2-690, U.S. Army Engineer Waterways Experiment Station, Vicksburg, MS.

Smith, O. P. (1984). "Alaskan harbor plan features to reduce dredging costs, Dredging and dredged material disposal," Proceedings of the Conference Dredging '84, ASCE. 1, 219-228.

Smits, J., Meyvis, L., and Wens, F. (1994). "Maintenance dredging in the river Scheldt, An environmental approach," ASCE Dredging 94, 499-508.

Teeter, A. M. (1989). "Effects of Cooper River rediversion flows on shoaling conditions at Charleston Harbor, Charleston, South Carolina," Technical Report HL-89-3, U.S. Army Engineer Waterways Experiment Station, Vicksburg, MS.

U.S. Army Engineer Waterways Experiment Station. (1961). "Savannah Harbor investigation and model study: Vol III, Results of model investigations, Section 2, Results of improvement plans," Technical Report No. 2-580, Vicksburg, MS.

. (1963). "Savannah Harbor investigation and model study: Vol III, Results of model investigations, Section 3, Results of supplemental tests," Technical Report No. 2-580, Vicksburg, MS.

Van Schundel, S. A. H, and Kranenburg, C. (1998). "Reducing the siltation of a river harbor," Journal of Hydraulic Research 36(5), 803.

Weishar, L. L., and Aubrey, D. G. (1988). "Inlet hydraulics at Green Harbor, Marshfield, Massachusetts," Miscellaneous Paper CERC-88-10, U.S. Army Engineer Waterways Experiment Station, Vicksburg, MS. 
Wicker, C. F., ed. (1965). "Evaluation of present state of knowledge of factors affecting tidal hydraulics and related phenomena," Committee on Tidal Hydraulics, U.S. Army Corps of Engineers.

Wicker, C. F., and Eaton, R.O. (1965). "Sedimentation in tidal waterways." Evaluation of present state of knowledge of factors affecting tidal hydraulics and related phenomena. Report No. 3, Committee on Tidal Hydraulics, U.S. Army Corps of Engineers. 


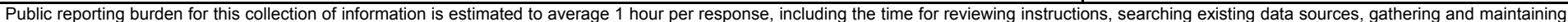

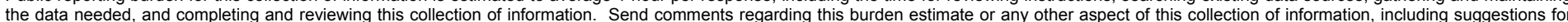

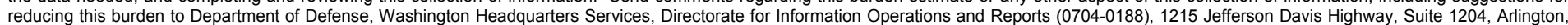

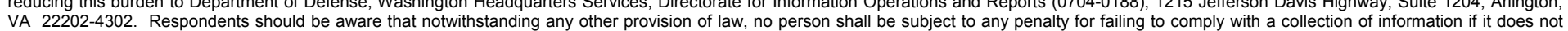
VA 22202-4302. Respondents should be aware that notwithstanding any other provision of law, no person shall be sube
display a currently valid OMB control number. PLEASE DO NOT RETURN YOUR FORM TO THE ABOVE ADDRESS.
1. REPORT DATE (DD-MM-YYYY)
September 2005

$$
\text { Final report }
$$

4. TITLE AND SUBTITLE

Structural Methods to Reduce Navigation Channel Shoaling
3. DATES COVERED (From - To)

\section{5a. CONTRACT NUMBER}

5b. GRANT NUMBER

5c. PROGRAM ELEMENT NUMBER

5d. PROJECT NUMBER

5e. TASK NUMBER

5f. WORK UNIT NUMBER

8. PERFORMING ORGANIZATION REPORT NUMBER

ERDC/CHL TR-05-13

U.S. Army Engineer Research and Development Center

Coastal and Hydraulics Laboratory

3909 Halls Ferry Road

Vicksburg, MS 39180-6199

\section{SPONSORING / MONITORING AGENCY NAME(S) AND ADDRESS(ES)}

U.S. Army Corps of Engineers

Washington, DC 20314-1000

10. SPONSOR/MONITOR'S ACRONYM(S)

11. SPONSOR/MONITOR'S REPORT NUMBER(S)

\section{DISTRIBUTION / AVAILABILITY STATEMENT}

Approved for public release; distribution is unlimited.

\section{SUPPLEMENTARY NOTES}

\section{ABSTRACT}

Shoaling of harbors and navigation channels is a global problem. Expensive dredging operation must be undertaken to remove accumulated sediment and maintain navigable depths to continue uninterrupted navigation. Since the draft of commercial vessels and oil tankers is continually increasing, the navigation channels are getting wider, deeper and longer, thus requiring greater maintenance dredging. The length of a navigation channel depends upon the local geographical configuration and it may vary from less than a mile to 50 miles or more.

It is absolutely essential to determine the important factors at play before considering an appropriate method for reducing siltation in navigation channels. These factors include: type of sediment, identification of sediment source, critical natural parameters involved, time scale of shoaling occurrence, and total volume of sediment. The types of available measures include reduce/prevent/catch/divert sediment inflow from the source, and prevent sediment recirculation/deposition. These methods may also be classified alternatively as structural methods, nonstructural methods, and management/other methods. The best-suited option for a given project must be well studied in advance to ensure its efficient functioning for the intended purpose. Sometimes, a combination of various methods may have to be used.

(Continued)

\begin{tabular}{ll} 
15. SUBJECT TERMS & Navigation channel \\
Coastal structures & Shoaling \\
Dredging & Siltation \\
\hline
\end{tabular}

16. SECURITY CLASSIFICATION OF:

\begin{tabular}{|l|l|l|}
\hline $\begin{array}{l}\text { a. REPORT } \\
\text { UNCLASSIFIED }\end{array}$ & $\begin{array}{l}\text { b. ABSTRACT } \\
\text { UNCLASSIFIED }\end{array}$ & $\begin{array}{c}\text { c. THIS PAGE } \\
\text { UNCLASSIFIED }\end{array}$ \\
\hline
\end{tabular}

Shoaling reduction

Structural methods

\begin{tabular}{l|c|}
\hline $\begin{array}{l}\text { 17. LIMITATION } \\
\text { OF ABSTRACT }\end{array}$ & $\begin{array}{c}\text { 18. NUMBER } \\
\text { OF PAGES }\end{array}$ \\
& 87 \\
&
\end{tabular}

19a. NAME OF RESPONSIBLE PERSON

19b. TELEPHONE NUMBER (include area code) 


\section{4. (Concluded)}

Incorporating structural modifications at project sites is often a viable and economical option for reducing shoaling in harbors and navigation channels. This option includes construction of massive and expensive structures such as dikes of various types, bendway weirs, breakwaters, jetties, weir jetties, sediment barriers, sediment traps, channel closing structure, flow diversion structures such as dams and canals, and current deflector walls. Structural methods are the most prevailing options selected for many projects and they are found to be effective in reducing channel shoaling. Use of such structures is described in this report along with description of numerous studies and examples of sites where they have been used. This report describes various options available for the designers and field engineers. Projects where such methods have been successfully implemented have been cited. Simulations made with the help of a schematic numerical model are given. Although structural remedies are often effective, they are mostly site-specific and should not be adopted without examining their applicability at a site under consideration. Detailed studies in the form of physical modeling, numerical modeling, field data collection and analysis and examination of successful measures adopted at other sites should be undertaken to select the best possible option for a given site under consideration. Several parameters, including environmental impact, must be taken into account while selecting a set of technically feasible and economically viable options. 